\title{
The Genus Cladosporium: A Rich Source of Diverse and Bioactive Natural Compounds
}

\author{
Maria Michela Salvatore ${ }^{1}\left(\mathbb{D}\right.$, Anna Andolfi $^{1,2, *}$ (D) and Rosario Nicoletti ${ }^{3,4}$ (D) \\ 1 Department of Chemical Sciences, University of Naples 'Federico II', 80126 Naples, Italy; \\ mariamichela.salvatore@unina.it \\ 2 BAT Center-Interuniversity Center for Studies on Bioinspired Agro-Environmental Technology, \\ University of Naples 'Federico II', Portici, 80055 Naples, Italy \\ 3 Council for Agricultural Research and Economics, Research Centre for Olive, Fruit and Citrus Crops, \\ 81100 Caserta, Italy; rosario.nicoletti@crea.gov.it \\ 4 Department of Agricultural Sciences, University of Naples 'Federico II', 80055 Portici, Italy \\ * Correspondence: andolfi@unina.it; Tel.: +39-081-2539179
}

check for updates

Citation: Salvatore, M.M.; Andolfi,

A.; Nicoletti, R. The Genus

Cladosporium: A Rich Source of

Diverse and Bioactive Natural

Compounds. Molecules 2021, 26, 3959.

https://doi.org/10.3390/

molecules26133959

Academic Editor: Francisco Leon

Received: 11 June 2021

Accepted: 24 June 2021

Published: 28 June 2021

Publisher's Note: MDPI stays neutral with regard to jurisdictional claims in published maps and institutional affiliations.

Copyright: (c) 2021 by the authors. Licensee MDPI, Basel, Switzerland. This article is an open access article distributed under the terms and conditions of the Creative Commons Attribution (CC BY) license (https:/ / creativecommons.org/licenses/by/ $4.0 /)$.

\begin{abstract}
Fungi are renowned as one of the most fruitful sources of chemodiversity and for their ubiquitous occurrence. Among the many taxonomic groupings considered for the implications deriving from their biosynthetic aptitudes, the genus Cladosporium stands out as one of the most common in indoor environments. A better understanding of the impact of these fungi on human health and activities is clearly based on the improvement of our knowledge of the structural aspects and biological properties of their secondary metabolites, which are reviewed in the present paper.
\end{abstract}

Keywords: natural products; bioactive secondary metabolites; fungal species; fungal extrolites

\section{Introduction}

Results of recent research in the mycological field have further disclosed the pervasive diffusion of fungi in the genus Cladosporium (Dothideomycetes, Cladosporiaceae). Basically saprophytic, these Ascomycetes are spread in every kind of terrestrial and marine environment, where they establish various symbiotic relationships with plants and animals [1]; moreover, they are among the most frequent fungi detected in indoor spaces [2,3]. This latter connotation implies obvious opportunities for interactions with people, which can sometimes evolve into undesirable effects in terms of allergic or even pathogenic reactions [4-8].

Over the past two decades, investigations into the occurrence of Cladosporium spp. have been boosted by their tremendous ecological adaptability, as well as their frequent implication in human activities and medical aspects. Fundamental support from the molecular tools for species identification has enabled mycologists to disclose an exceptional taxonomic variation, with as many as 218 accepted species considered in the most recent update [3] and more new species added to the list in the last three years [9-11]. Considering the importance of secondary metabolites as mediators of biological interactions, this versatility has also generated notable research activity concerning the metabolome of these fungi and its biological properties, which are revised in the present paper.

\section{Fifty Years of Metabolomic Studies in Cladosporium}

A set of 68 Cladosporium strains have been examined so far, about $2 / 3$ of which have been formally classified at the species level and ascribed to 12 taxa (Table 1). In this respect, the most frequent species are represented by the progenitors of the three main species complexes of the genus $[1,3]$. This may imply that in some cases the taxonomic identification has been approximate, as it only relied on morphological characters or ITS sequences. Concerning the origin, the examined strains are almost equally distributed 
between terrestrial and marine sources, with a prevalence of those recovered as endophytes or from sediments (Figure 1).

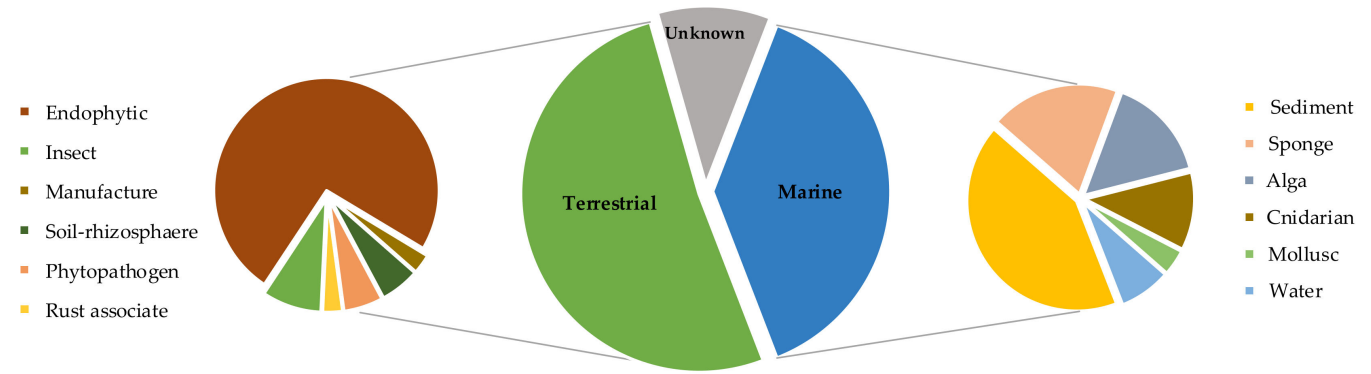

Figure 1. Pie charts of the origin of the strains examined in the present review.

Despite the low number of strains, a long list of products has been reported from Cladosporium, starting with the finding of cladosporin in 1971 [12]. In fact, from analysis of the available literature, a total of 244 chemically defined compounds can be extracted, belonging to different classes of secondary metabolites, such as azaphilones, benzofluoranthenones, coumarins and isocumarins, lactones, naphthalenones, macrolides, perylenequinones, sterols and others (Table 2). Of course, this list includes both known metabolites and compounds, which have been first characterized from these fungi, with the latter representing a remarkable share $(147$, corresponding to about $60 \%)$. In our survey, we avoided considering some products that are known intermediates in biosynthetic processes, clearly represent possible contaminants of the fungal cultures, or were just tentatively identified [13-21].

Table 1. Cladosporium species/strains reported for production of secondary metabolites.

\begin{tabular}{|c|c|c|c|}
\hline Species/Strain & Substrate & Location & Refs. \\
\hline C. cladosporioides & - & - & [12] \\
\hline C. cladosporioides & sediment of hypersaline lake & El Hamra, Egypt & [22] \\
\hline C. cladosporioides & sponge (Cliona sp.) & Los Molles, Chile & [23] \\
\hline C. cladosporioides & aphid (Aphis craccivora) & Egypt & {$[17,18]$} \\
\hline C. cladosporioides & endophytic in Zygophyllum mandavillei & Al-Ahsa, Saudi Arabia & [24] \\
\hline C. cladosporioides & endophytic in unspecified plant & Tifton, United States & [25] \\
\hline C. cladosporioides & - & Japan & [26] \\
\hline C. cladosporioides/CBUK20700 & dead insect & Thailand & {$[27,28]$} \\
\hline C. cladosporioides/FERMBP-1285 & block fence & Osaka, Japan & {$[29,30]$} \\
\hline C. cladosporioides /IPV-F167 & - & Italy & [31] \\
\hline C. cladosporioides/LWL5 & endophytic in Helianthus annuus & Daegu, South Korea & [16] \\
\hline C. cladosporioides /MA-299 & endophytic in Bruguiera gymnorrhiza & Hainan, China & [32-34] \\
\hline C. cladosporioides/MCCC3A00182 & deep sea sediment & Pacific Ocean & [35] \\
\hline C. cladosporioides/MUPGBIOCHEM-CC-07-2015 & brown alga (Sargassum wightii) & Tamil Nadu, India & [21] \\
\hline C. cladosporioides/NRRL5507 & - & - & {$[36,37]$} \\
\hline C. cladosporioides/CL-1 & rhizosphere of red pepper & South Korea & [38] \\
\hline C. cladosporioides/EN-399 & red alga (Laurencia okamurai) & Qingdao, China & [39] \\
\hline C. cladosporioides/HDN14-342 & deep sea sediment & Indian Ocean & [40] \\
\hline C. colocasiae/A801 & endophytic in Callistemon viminalis & Guangzhou, China & [41] \\
\hline C. delicatulum/EF33 & endophytic in Terminalia pallida & Andhra Pradesh, India & [42] \\
\hline C. halotolerans/GXIMD 02502 & coral (Porites lutea) & Weizhou islands, China & [43] \\
\hline C. herbarum & sponge (Callyspongia aerizusa) & Bali, Indonesia & {$[44,45]$} \\
\hline
\end{tabular}


Table 1. Cont.

\begin{tabular}{|c|c|c|c|}
\hline Species/Strain & Substrate & Location & Refs. \\
\hline C. herbarum/FC27P & endophytic in Beta vulgaris & Dublin, United States & [46] \\
\hline C. herbarum/IFB-E002 & endophytic in Cynodon dactylon & Yancheng reserve, China & [47] \\
\hline C. oxysporum & endophytic in Aglaia odorata & Java, Indonesia & [14] \\
\hline C. oxysporum & endophytic in Alyxia reinwardtii & Java, Indonesia & [48] \\
\hline C. oxysporum/DH14 & locust (Oxya chinensis) & Jinhua, China & [49] \\
\hline C. oxysporum/HDN13-314 & endophytic in Avicennia marina & Hainan, China & [50] \\
\hline C. oxysporum/RM1 & endophytic in Moringa oleifera & Tamil Nadu, India & [51] \\
\hline C. perangustum/FS62 & deep sea sediment & South China Sea & [52] \\
\hline C. phlei/C-273 w & pathogenic on Phleum pratense & Hokkaido, Japan & [53] \\
\hline C. phlei/CBS 358.69 & pathogenic on Phleum pratense & Germany & [54] \\
\hline C. sphaerospermum/2005-01-E3 & deep sea sludge & Pacific Ocean & {$[55,56]$} \\
\hline C. sphaerospermum/DK-1-1 & endophytic in Glycine max & South Korea & [57] \\
\hline C. sphaerospermum/EIODSF 008 & deep sea sediment & Indian Ocean & [58] \\
\hline C. sphaerospermum/L3P3 & deep sea sediment & Mariana Trench & [59] \\
\hline C. sphaerospermum/SW67 & hydroid (Hydractinia echinata) & South Korea & [60-62] \\
\hline C. sphaerospermum/WBS017 & $\begin{array}{c}\text { endophytic in Fritillaria unibracteata } \\
\text { var. wabuensis }\end{array}$ & China & [63] \\
\hline C. tenuissimum & soil & Karo-cho, Japan & [64] \\
\hline C. tenuissimum/DMG 3 & endophytic in Swietenia mahagoni & Sumatra, Indonesia & [65] \\
\hline C. tenuissimum/ITT21 & pine rust (Cronartium flaccidum) & Tuscany, Italy & [66] \\
\hline C. tenuissimum/LR463 & endophytic in Maytenus hookeri & Yunnan, China & [67] \\
\hline C. tenuissimum/P1S11 & endophytic in Pinus wallichiana & Kashmir, India & [68] \\
\hline C. uredinicola & endophytic in Psidium guajava & São Carlos, Brazil & [69] \\
\hline C. velox/TN-9S & endophytic in Tinospora cordifolia & Amritsar, India & [70] \\
\hline Cladosporium sp. & sponge (Niphates rowi) & Gulf of Aqaba, Israel & [71] \\
\hline Cladosporium sp./486 & intertidal sediment & San Antonio Oeste, Argentina & [19] \\
\hline Cladosporium sp./501-7w & - & Japan & {$[72-74]$} \\
\hline Cladosporium sp./F14 & sea water & Sai Kung, China & {$[13,75]$} \\
\hline Cladosporium sp./HDN17-58 & deep sea sediment & Pacific Ocean & [76] \\
\hline Cladosporium sp./I(R)9-2 & endophytic in Quercus variabilis & Nanjing, China & [77] \\
\hline Cladosporium sp./IFB3lp-2 & endophytic in Rhizophora stylosa & Hainan, China & [78] \\
\hline Cladosporium sp./IFM 49189 & - & Japan & {$[79,80]$} \\
\hline Cladosporium sp./JJM22 & endophytic in Ceriops tagal & Hainan, China & [81-83] \\
\hline Cladosporium sp./JNU17DTH12-9-0 & unknown & China & [84] \\
\hline Cladosporium sp./JS1-2 & endophytic in Ceriops tagal & Hainan, China & [85] \\
\hline Cladosporium sp./KcFL6' & endophytic in Kandelia candel & Daya Bay, China & [86] \\
\hline Cladosporium sp./KFD33 & blood cockle & Hainan, China & [87] \\
\hline Cladosporium sp./L037 & brown alga (Actinotrichia fragilis) & Okinawa, Japan & [88] \\
\hline Cladosporium sp./N5 & red alga (Porphyra yezoensis) & Lianyungang, China & [15] \\
\hline Cladosporium sp./OUCMDZ-1635 & sponge & Xisha Islands, China & [89] \\
\hline Cladosporium sp./RSBE-3 & endophytic in Rauwolfia serpentina & Bangladesh & [90] \\
\hline Cladosporium sp./SCNU-F0001 & endophytic in unspecified mangrove & Zhuhai, China & [91] \\
\hline Cladosporium sp./SCSIO z01 & deep sea sediment & East China Sea & [92] \\
\hline Cladosporium sp./TPU1507 & unidentified sponge & Manado, Indonesia & [93] \\
\hline Cladosporium sp./TZP-29 & unidentified soft coral & Guangzhou, China & [94] \\
\hline Cladosporium sp./KF501 & water sample & Wadden Sea, Germany & [95] \\
\hline Cladosporium sp./SCSIO z0025 & deep sea sediment & Okinawa, Japan & [96] \\
\hline
\end{tabular}


Some errors and overlapping in the compound names attribution have arisen during the accurate examination of the available literature on this topic. In particular, we can consider two recurring issues, which are "more names, one chemical structure" and "one name, more chemical structures". For instance, cladosporin certainly belongs to the first case because its chemical structure is also known by the name asperentin [97]. For this reason, in Table 2, we added in brackets eventual additional names for compounds that fall under this case.

On the other hand, due to the intense research activity concerning this fungal genus, it has happened that some authors conducted their research parallel to the finding of closely related compounds. The temporal proximity in publishing has sometimes caused the attribution of the same name to different chemical structures (e.g., cladosporiumin I). In the case of cladosporol $G$, this issue was rather a consequence of author inaccuracy, since the elapsed time of about one year between the consecutive reports would have afforded an accurate preliminary check. In all cases of homonymy in Table 2, we have added the Latin suffix "bis" to the compounds that have been characterized later, as inferred from the date of submission to the journal.

Additional nomenclatural issues are represented by the absence of a proposed name, or authors' choice to follow IUPAC rules instead of introducing trivial names derived from closely related compounds. Indeed, the use of trivial names represents a very common and useful guideline in natural product research because systematic names can be so convoluted and difficult to parse.

Table 2. List of secondary metabolites produced by Cladosporium species. The Latin suffix "bis" is added when the same name has been previously introduced for another compound. The names of novel compounds are underlined.

\begin{tabular}{|c|c|c|c|c|}
\hline Code & Name & Formula & Nominal Mass (U) & Refs. \\
\hline \multicolumn{5}{|c|}{ Alkaloids } \\
\hline 1 & Aspernigrin A & $\mathrm{C}_{13} \mathrm{H}_{12} \mathrm{~N}_{2} \mathrm{O}_{2}$ & 228 & [47] \\
\hline 2 & Aspidospermidin-20-ol, 1-acetyl-17-methoxy & $\mathrm{C}_{22} \mathrm{H}_{30} \mathrm{~N}_{2} \mathrm{O}_{3}$ & 370 & [24] \\
\hline 3 & Cladosin E & $\mathrm{C}_{13} \mathrm{H}_{17} \mathrm{NO}_{4}$ & 251 & [55] \\
\hline 4 & Cladosporine A & $\mathrm{C}_{28} \mathrm{H}_{39} \mathrm{NO}_{2}$ & 421 & [84] \\
\hline 5 & Cytochalasin D & $\mathrm{C}_{30} \mathrm{H}_{37} \mathrm{NO}_{6}$ & 507 & [85] \\
\hline 6 & 2-Methylacetate-3,5,6-trimethylpyrazine & $\mathrm{C}_{10} \mathrm{H}_{14} \mathrm{~N}_{2} \mathrm{O}_{2}$ & 194 & [85] \\
\hline 7 & Nonanal oxime & $\mathrm{C}_{9} \mathrm{H}_{19} \mathrm{NO}$ & 157 & [17] \\
\hline 8 & 2-Piperidinone methyl & $\mathrm{C}_{6} \mathrm{H}_{11} \mathrm{NO}$ & 113 & [17] \\
\hline \multicolumn{5}{|c|}{ Azaphilones } \\
\hline 9 & Bicyclic diol & $\mathrm{C}_{11} \mathrm{H}_{14} \mathrm{O}_{4}$ & 210 & [52] \\
\hline 10 & Lunatoic acid A & $\mathrm{C}_{21} \mathrm{H}_{24} \mathrm{O}_{7}$ & 388 & [49] \\
\hline 11 & Perangustol A & $\mathrm{C}_{11} \mathrm{H}_{14} \mathrm{O}_{4}$ & 210 & [52] \\
\hline 12 & Perangustol B & $\mathrm{C}_{11} \mathrm{H}_{14} \mathrm{O}_{4}$ & 210 & [52] \\
\hline \multicolumn{5}{|c|}{ Benzofluoranthenones } \\
\hline 13 & $\frac{(6 \mathrm{bS}, 7 R, 8 S)-4,9-\mathrm{Dihydroxy}-7,8 \text {-dimethoxy-1,6b,7,8-tetra- }}{\text { hydro-2H-benzo[J]fluoranthen-3-one }}$ & $\mathrm{C}_{23} \mathrm{H}_{22} \mathrm{O}_{4}$ & 362 & [27] \\
\hline 14 & $\begin{array}{l}\text { methoxy-1,2,6b,7-tetrahydrobenzo[J]fluoranthen-3,8-dione } \\
\text { methe-49-Dihydroxy-7- }\end{array}$ & $\mathrm{C}_{22} \mathrm{H}_{18} \mathrm{O}_{4}$ & 346 & [27] \\
\hline 15 & 1,6b,7,8-tetrahydro-2H-benzo[J]fluoranthen-3-one & $\mathrm{C}_{22} \mathrm{H}_{20} \mathrm{O}_{4}$ & 348 & [27] \\
\hline 16 & 1,6b,7,8-tetrahydro-2H-benzo[J]fluoranthen-3-one & $\mathrm{C}_{22} \mathrm{H}_{20} \mathrm{O}_{4}$ & 348 & {$[27,28]$} \\
\hline \multicolumn{5}{|c|}{ Benzopyranones } \\
\hline 17 & Coniochaetone A & $\mathrm{C}_{13} \mathrm{H}_{10} \mathrm{O}_{4}$ & 230 & [43] \\
\hline 18 & Coniochaetone B & $\mathrm{C}_{13} \mathrm{H}_{12} \mathrm{O}_{4}$ & 232 & [43] \\
\hline 19 & Coniochaetone $\mathrm{K}$ & $\mathrm{C}_{13} \mathrm{H}_{10} \mathrm{O}_{6}$ & 262 & [43] \\
\hline
\end{tabular}


Table 2. Cont.

\begin{tabular}{|c|c|c|c|c|}
\hline Code & Name & Formula & Nominal Mass (U) & Refs. \\
\hline \multicolumn{5}{|c|}{ Binaphthopyrones } \\
\hline 20 & Cladosporinone & $\mathrm{C}_{33} \mathrm{H}_{30} \mathrm{O}_{14}$ & 650 & {$[22]$} \\
\hline 21 & Viriditoxin & $\mathrm{C}_{34} \mathrm{H}_{30} \mathrm{O}_{14}$ & 662 & {$[22]$} \\
\hline 22 & Viriditoxin SC-28763 & $\mathrm{C}_{34} \mathrm{H}_{30} \mathrm{O}_{13}$ & 646 & {$[22]$} \\
\hline 23 & Viriditoxin SC-30532 & $\mathrm{C}_{34} \mathrm{H}_{30} \mathrm{O}_{12}$ & 630 & [22] \\
\hline \multicolumn{5}{|c|}{ Butenolides and butanolides } \\
\hline 24 & Cladospolide F & $\mathrm{C}_{12} \mathrm{H}_{22} \mathrm{O}_{4}$ & 230 & [94] \\
\hline 25 & Cladospolide G & $\mathrm{C}_{14} \mathrm{H}_{24} \mathrm{O}_{5}$ & 272 & [32] \\
\hline 26 & Cladospolide $\mathrm{H}$ & $\mathrm{C}_{12} \mathrm{H}_{18} \mathrm{O}_{3}$ & 210 & [32] \\
\hline 27 & ent-Cladospolide F & $\mathrm{C}_{12} \mathrm{H}_{22} \mathrm{O}_{4}$ & 230 & [32] \\
\hline 28 & 11-Hydroxy- $\gamma$-dodecalactone & $\mathrm{C}_{12} \mathrm{H}_{20} \mathrm{O}_{3}$ & 212 & [94] \\
\hline 29 & iso-Cladospolide B & $\mathrm{C}_{12} \mathrm{H}_{20} \mathrm{O}_{4}$ & 228 & {$[32,44,50,67,71,94]$} \\
\hline \multicolumn{5}{|c|}{ Cinnamic acid derivatives } \\
\hline 30 & Chlorogenic acid & $\mathrm{C}_{16} \mathrm{H}_{18} \mathrm{O}_{9}$ & 354 & [70] \\
\hline 31 & Caffeic acid & $\mathrm{C}_{9} \mathrm{H}_{8} \mathrm{O}_{4}$ & 180 & [70] \\
\hline 32 & Coumaric acid & $\mathrm{C}_{9} \mathrm{H}_{8} \mathrm{O}_{3}$ & 164 & [70] \\
\hline \multicolumn{5}{|c|}{ Citrinin derivatives } \\
\hline 33 & Citrinin $\mathrm{H} 1$ & $\mathrm{C}_{25} \mathrm{H}_{30} \mathrm{O}_{7}$ & 442 & [85] \\
\hline 34 & Cladosporin A & $\mathrm{C}_{13} \mathrm{H}_{15} \mathrm{NO}_{3}$ & 233 & [92] \\
\hline 35 & Cladosporin B & $\mathrm{C}_{13} \mathrm{H}_{15} \mathrm{NO}_{3}$ & 233 & {$[92]$} \\
\hline 36 & Cladosporin C & $\mathrm{C}_{14} \mathrm{H}_{16} \mathrm{O}_{4}$ & 248 & [92] \\
\hline 37 & Cladosporin D & $\mathrm{C}_{12} \mathrm{H}_{16} \mathrm{O}_{4}$ & 224 & [92] \\
\hline \multicolumn{5}{|c|}{ Coumarins and Isocoumarins } \\
\hline 38 & Asperentin-8-methyl ether (= cladosporin-8-methyl ether) & $\mathrm{C}_{17} \mathrm{H}_{22} \mathrm{O}_{6}$ & 322 & [25] \\
\hline 39 & Cladosporin (= asperentin) & $\mathrm{C}_{16} \mathrm{H}_{20} \mathrm{O}_{5}$ & 292 & {$[12,24,25,36,37]$} \\
\hline 40 & 5'-Hydroxyasperentin & $\mathrm{C}_{16} \mathrm{H}_{20} \mathrm{O}_{6}$ & 308 & {$[24,25]$} \\
\hline 41 & 7-Hydroxy-4-methoxy-5-methylcoumarin & $\mathrm{C}_{11} \mathrm{H}_{10} \mathrm{O}_{4}$ & 206 & [47] \\
\hline 42 & Isocladosporin & $\mathrm{C}_{16} \mathrm{H}_{20} \mathrm{O}_{5}$ & 292 & {$[24,25,37]$} \\
\hline 43 & Kotanin & $\mathrm{C}_{24} \mathrm{H}_{22} \mathrm{O}_{8}$ & 438 & [47] \\
\hline 44 & Orlandin & $\mathrm{C}_{22} \mathrm{H}_{18} \mathrm{O}_{8}$ & 410 & [47] \\
\hline 45 & Phomasatin & $\mathrm{C}_{10} \mathrm{H}_{8} \mathrm{O}_{5}$ & 208 & [35] \\
\hline 46 & Umbelliferone & $\mathrm{C}_{9} \mathrm{H}_{6} \mathrm{O}_{3}$ & 162 & [70] \\
\hline \multicolumn{5}{|c|}{ Cyclohexene derivatives } \\
\hline 47 & Cladoscyclitol A & $\mathrm{C}_{12} \mathrm{H}_{20} \mathrm{O}_{5}$ & 244 & {$[82]$} \\
\hline 48 & Cladoscyclitol B & $\mathrm{C}_{13} \mathrm{H}_{22} \mathrm{O}_{7}$ & 290 & {$[82]$} \\
\hline 49 & Cladoscyclitol C & $\mathrm{C}_{12} \mathrm{H}_{22} \mathrm{O}_{4}$ & 230 & {$[82]$} \\
\hline 50 & Cladoscyclitol D & $\mathrm{C}_{12} \mathrm{H}_{22} \mathrm{O}_{5}$ & 246 & [82] \\
\hline \multicolumn{5}{|c|}{ Despsides } \\
\hline 51 & $\frac{\text { 3-Hydroxy-2,4,5-trimethylphenyl 2,4-dihydroxy- }}{\text { 3,6-dimethylbenzoate }}$ & $\mathrm{C}_{18} \mathrm{H}_{20} \mathrm{O}_{5}$ & 316 & {$[69,98]$} \\
\hline 52 & $\begin{array}{c}\text { 3-Hydroxy-2,4,5-trimethylphenyl 4-[(2,4-dihydroxy- } \\
\text { 3,6-dimethylbenzoyl)oxy]-2-hydroxy-3,6-dimethylbenzoate } \\
\end{array}$ & $\mathrm{C}_{27} \mathrm{H}_{28} \mathrm{O}_{8}$ & 480 & {$[69,98]$} \\
\hline 53 & $\frac{\text { 3-Hydroxy-2,5-dimethylphenyl 2,4-dihydroxy- }}{\text { 3,6-dimethylbenzoate }}$ & $\mathrm{C}_{17} \mathrm{H}_{18} \mathrm{O}_{5}$ & 302 & {$[69,98]$} \\
\hline 54 & $\begin{array}{l}\text { 3-Hydroxy-2,5-dimethylphenyl 4-[(2,4-dihydroxy- } \\
\text { 3,6-dimethylbenzoyl)oxy]-2-hydroxy-3,6-dimethylbenzoate }\end{array}$ & $\mathrm{C}_{26} \mathrm{H}_{26} \mathrm{O}_{8}$ & 466 & {$[69,98]$} \\
\hline
\end{tabular}


Table 2. Cont

\begin{tabular}{|c|c|c|c|c|}
\hline Code & Name & Formula & Nominal Mass (U) & Refs. \\
\hline \multicolumn{5}{|c|}{ Diketopiperazines } \\
\hline 55 & $(3 R, 8 \mathrm{a} R)-C y c l o($ leucylprolyl) & $\mathrm{C}_{11} \mathrm{H}_{18} \mathrm{~N}_{2} \mathrm{O}_{2}$ & 210 & [17] \\
\hline 56 & $(3 S, 8 \mathrm{a} S)-C y c l o($ leucylprolyl) & $\mathrm{C}_{11} \mathrm{H}_{18} \mathrm{~N}_{2} \mathrm{O}_{2}$ & 210 & [17] \\
\hline 57 & $(3 R, 8 \mathrm{a} R)-C y c l o($ phenylalanylprolyl) & $\mathrm{C}_{14} \mathrm{H}_{16} \mathrm{~N}_{2} \mathrm{O}_{2}$ & 244 & [17] \\
\hline 58 & $(3 S, 8 \mathrm{a} S)-C y c l o($ phenylalanylprolyl) & $\mathrm{C}_{14} \mathrm{H}_{16} \mathrm{~N}_{2} \mathrm{O}_{2}$ & 244 & [17] \\
\hline \multicolumn{5}{|c|}{ Flavonoids } \\
\hline 59 & (2S)-7,4'-Dihydroxy-5-methoxy-8-( $\gamma, \gamma$-dimethylallyl)-flavanone & $\mathrm{C}_{21} \mathrm{H}_{22} \mathrm{O}_{5}$ & 354 & [93] \\
\hline 60 & Catechin & $\mathrm{C}_{15} \mathrm{H}_{14} \mathrm{O}_{6}$ & 290 & [70] \\
\hline 61 & Epicatechin & $\mathrm{C}_{15} \mathrm{H}_{14} \mathrm{O}_{6}$ & 290 & [70] \\
\hline \multicolumn{5}{|c|}{ Gibberelines } \\
\hline 62 & GA3 & $\mathrm{C}_{19} \mathrm{H}_{22} \mathrm{O}_{6}$ & 346 & [57] \\
\hline 63 & GA4 & $\mathrm{C}_{19} \mathrm{H}_{24} \mathrm{O}_{5}$ & 332 & [57] \\
\hline 64 & GA5 & $\mathrm{C}_{19} \mathrm{H}_{22} \mathrm{O}_{5}$ & 330 & [57] \\
\hline 65 & GA7 & $\mathrm{C}_{19} \mathrm{H}_{22} \mathrm{O}_{5}$ & 330 & [57] \\
\hline 66 & GA15 & $\mathrm{C}_{20} \mathrm{H}_{26} \mathrm{O}_{4}$ & 330 & [57] \\
\hline 67 & GA19 & $\mathrm{C}_{20} \mathrm{H}_{26} \mathrm{O}_{6}$ & 362 & [57] \\
\hline 68 & GA24 & $\mathrm{C}_{20} \mathrm{H}_{26} \mathrm{O}_{5}$ & 346 & [57] \\
\hline \multicolumn{5}{|c|}{ Fusicoccane diterpene glycosides } \\
\hline 69 & Cotylenin A & $\mathrm{C}_{33} \mathrm{H}_{50} \mathrm{O}_{11}$ & 622 & [72-74] \\
\hline 70 & Cotylenin B & $\mathrm{C}_{33} \mathrm{H}_{51} \mathrm{ClO}_{11}$ & 659 & {$[73,74]$} \\
\hline 71 & Cotylenin C & $\mathrm{C}_{33} \mathrm{H}_{52} \mathrm{O}_{11}$ & 624 & [73] \\
\hline 72 & Cotylenin D & $\mathrm{C}_{33} \mathrm{H}_{52} \mathrm{O}_{12}$ & 640 & [73] \\
\hline 73 & Cotylenin E & $\mathrm{C}_{28} \mathrm{H}_{46} \mathrm{O}_{9}$ & 526 & [73] \\
\hline \multicolumn{5}{|c|}{ Lactones } \\
\hline 74 & Cladosporactone A & $\mathrm{C}_{10} \mathrm{H}_{12} \mathrm{O}_{4}$ & 196 & [35] \\
\hline 75 & Cladosporamide A & $\mathrm{C}_{14} \mathrm{H}_{11} \mathrm{NO}_{5}$ & 273 & [93] \\
\hline 76 & 5-Decanolide & $\mathrm{C}_{10} \mathrm{H}_{18} \mathrm{O}_{2}$ & 170 & [17] \\
\hline 77 & Herbaric acid & $\mathrm{C}_{10} \mathrm{H}_{8} \mathrm{O}_{6}$ & 224 & [45] \\
\hline 78 & Isochracinic acid & $\mathrm{C}_{10} \mathrm{H}_{8} \mathrm{O}_{5}$ & 208 & {$[35]$} \\
\hline \multicolumn{5}{|c|}{ Macrolides } \\
\hline 79 & Brefeldin A & $\mathrm{C}_{16} \mathrm{H}_{24} \mathrm{O}_{4}$ & 280 & [77] \\
\hline 80 & Cladocladosin A & $\mathrm{C}_{13} \mathrm{H}_{18} \mathrm{O}_{3}$ & 222 & {$[34]$} \\
\hline 81 & Cladospamide A & $\mathrm{C}_{13} \mathrm{H}_{20} \mathrm{~N}_{2} \mathrm{O}_{4}$ & 268 & [91] \\
\hline 82 & Cladospolide A & $\mathrm{C}_{12} \mathrm{H}_{20} \mathrm{O}_{4}$ & 228 & {$[41,64,67,78,91]$} \\
\hline 83 & Cladospolide B & $\mathrm{C}_{12} \mathrm{H}_{20} \mathrm{O}_{4}$ & 228 & {$[44,64,67,78]$} \\
\hline 84 & Cladospolide C & $\mathrm{C}_{12} \mathrm{H}_{20} \mathrm{O}_{4}$ & 228 & {$[64]$} \\
\hline 85 & 4,5-Dihydroxy-12-methyloxacyclododecan-2-one & $\mathrm{C}_{12} \mathrm{H}_{22} \mathrm{O}_{4}$ & 230 & [67] \\
\hline 86 & (6R,12S)-6-Hydroxy-12-methyl-oxacyclodoecane-2,5-dione & $\mathrm{C}_{12} \mathrm{H}_{20} \mathrm{O}_{4}$ & 228 & [67] \\
\hline 87 & (10S,12S)-10-Hydroxy-12-methyloxacyclododecane-2,5-dione & $\mathrm{C}_{12} \mathrm{H}_{20} \mathrm{O}_{4}$ & 228 & [67] \\
\hline 88 & 4-Hydroxy-12-methyloxacyclododecane-2,5,6-trione & $\mathrm{C}_{12} \mathrm{H}_{18} \mathrm{O}_{5}$ & 242 & {$[41]$} \\
\hline 89 & $\frac{(E)-(3 R, 6 S)-6 \text {-Hydroxy-12-methyl-2,5-dioxooxacyclododecan- }}{\text { 3-yl 4,11-dihydroxydodec-2-enoate }}$ & $\mathrm{C}_{24} \mathrm{H}_{40} \mathrm{O}_{8}$ & 456 & [78] \\
\hline 90 & 5R-Hydroxyrecifeiolide & $\mathrm{C}_{12} \mathrm{H}_{20} \mathrm{O}_{3}$ & 212 & [32] \\
\hline 91 & 5S-Hydroxyrecifeiolide & $\mathrm{C}_{12} \mathrm{H}_{20} \mathrm{O}_{3}$ & 212 & [32] \\
\hline 92 & 12-Methyloxacyclododecane-2,5,6-trione & $\mathrm{C}_{12} \mathrm{H}_{18} \mathrm{O}_{4}$ & 226 & [41] \\
\hline
\end{tabular}


Table 2. Cont.

\begin{tabular}{|c|c|c|c|c|}
\hline Code & Name & Formula & Nominal Mass (U) & Refs. \\
\hline 93 & $\frac{\text { Methyl 2-(((4R,6S,12R)-6-hydroxy-12-methyl- }}{\text { 2,5-dioxooxacyclododecan-4-yl)thio)acetate }}$ & $\mathrm{C}_{15} \mathrm{H}_{24} \mathrm{O}_{6} \mathrm{~S}$ & 332 & [78] \\
\hline 94 & 5Z-7-Oxozeaenol & $\mathrm{C}_{19} \mathrm{H}_{22} \mathrm{O}_{7}$ & 362 & [49] \\
\hline 95 & Pandangolide 1 & $\mathrm{C}_{12} \mathrm{H}_{20} \mathrm{O}_{5}$ & 244 & {$[32,41,48,71,78]$} \\
\hline 96 & Pandangolide 1a & $\mathrm{C}_{12} \mathrm{H}_{20} \mathrm{O}_{5}$ & 244 & {$[71,78]$} \\
\hline 97 & Pandangolide 2 & $\mathrm{C}_{14} \mathrm{H}_{22} \mathrm{O}_{6} \mathrm{~S}$ & 318 & {$[44,78]$} \\
\hline 98 & Pandangolide 3 & $\mathrm{C}_{16} \mathrm{H}_{26} \mathrm{O}_{7} \mathrm{~S}$ & 362 & {$[33,44,50,78]$} \\
\hline 99 & Pandangolide 4 & $\mathrm{C}_{24} \mathrm{H}_{38} \mathrm{O}_{8} \mathrm{~S}$ & 486 & [44] \\
\hline 100 & Patulolide B & $\mathrm{C}_{13} \mathrm{H}_{20} \mathrm{O}_{3}$ & 224 & [41] \\
\hline 101 & Sporiolide A & $\mathrm{C}_{19} \mathrm{H}_{24} \mathrm{O}_{6}$ & 348 & [88] \\
\hline 102 & $\underline{\text { Sporiolide B }}$ & $\mathrm{C}_{14} \mathrm{H}_{24} \mathrm{O}_{4}$ & 256 & [88] \\
\hline 103 & Thiocladospolide A & $\mathrm{C}_{16} \mathrm{H}_{26} \mathrm{O}_{6} \mathrm{~S}$ & 346 & {$[33,50]$} \\
\hline 104 & Thiocladospolide B & $\mathrm{C}_{16} \mathrm{H}_{24} \mathrm{O}_{7} \mathrm{~S}$ & 360 & [33] \\
\hline 105 & Thiocladospolide C & $\mathrm{C}_{15} \mathrm{H}_{22} \mathrm{O}_{6} \mathrm{~S}$ & 330 & [33] \\
\hline 106 & Thiocladospolide D & $\mathrm{C}_{16} \mathrm{H}_{28} \mathrm{O}_{7} \mathrm{~S}$ & 364 & [33] \\
\hline 107 & Thiocladospolide E & $\mathrm{C}_{14} \mathrm{H}_{26} \mathrm{O}_{5} \mathrm{~S}$ & 306 & [91] \\
\hline 108 & Thiocladospolide $\mathrm{F}$ & $\mathrm{C}_{16} \mathrm{H}_{28} \mathrm{O}_{5} \mathrm{~S}$ & 332 & [34] \\
\hline 109 & Thiocladospolide F bis & $\mathrm{C}_{24} \mathrm{H}_{38} \mathrm{O}_{8} \mathrm{~S}$ & 486 & [50] \\
\hline 110 & Thiocladospolide G & $\mathrm{C}_{16} \mathrm{H}_{28} \mathrm{O}_{6} \mathrm{~S}$ & 348 & [34] \\
\hline 111 & Thiocladospolide G bis & $\mathrm{C}_{15} \mathrm{H}_{24} \mathrm{O}_{7} \mathrm{~S}$ & 348 & [50] \\
\hline 112 & Thiocladospolide $\mathrm{H}$ & $\mathrm{C}_{15} \mathrm{H}_{24} \mathrm{O}_{6} \mathrm{~S}$ & 332 & [50] \\
\hline 113 & Thiocladospolide I & $\mathrm{C}_{27} \mathrm{H}_{44} \mathrm{O}_{10} \mathrm{~S}$ & 560 & [50] \\
\hline 114 & Thiocladospolide J & $\mathrm{C}_{27} \mathrm{H}_{42} \mathrm{O}_{10} \mathrm{~S}$ & 558 & [50] \\
\hline 115 & Zeaenol & $\mathrm{C}_{19} \mathrm{H}_{24} \mathrm{O}_{7}$ & 364 & [49] \\
\hline \multicolumn{5}{|c|}{ Naphthalene derivatives } \\
\hline 116 & Cladonaphchrom A & $\mathrm{C}_{22} \mathrm{H}_{22} \mathrm{O}_{4}$ & 350 & [83] \\
\hline 117 & Cladonaphchrom B & $\mathrm{C}_{22} \mathrm{H}_{22} \mathrm{O}_{4}$ & 350 & [83] \\
\hline 118 & 1,8-Dimethoxynaphthalene & $\mathrm{C}_{12} \mathrm{H}_{12} \mathrm{O}_{2}$ & 188 & {$[81,83]$} \\
\hline 119 & 8-Methoxynaphthalen-1-ol & $\mathrm{C}_{11} \mathrm{H}_{10} \mathrm{O}_{2}$ & 174 & [83] \\
\hline \multicolumn{5}{|c|}{ Naphtalenones } \\
\hline 120 & Altertoxin XII & $\mathrm{C}_{20} \mathrm{H}_{18} \mathrm{O}_{4}$ & 322 & [87] \\
\hline 121 & Cladosporol A & $\mathrm{C}_{20} \mathrm{H}_{16} \mathrm{O}_{6}$ & 352 & {$[26,66,86]$} \\
\hline 122 & Cladosporol B & $\mathrm{C}_{20} \mathrm{H}_{14} \mathrm{O}_{6}$ & 350 & [66] \\
\hline 123 & Cladosporol C & $\mathrm{C}_{20} \mathrm{H}_{18} \mathrm{O}_{5}$ & 338 & {$[35,39,40,66,85,86]$} \\
\hline 124 & Cladosporol D & $\mathrm{C}_{20} \mathrm{H}_{18} \mathrm{O}_{6}$ & 354 & {$[66,86]$} \\
\hline 125 & Cladosporol E & $\mathrm{C}_{20} \mathrm{H}_{18} \mathrm{O}_{7}$ & 370 & {$[40,66,85]$} \\
\hline 126 & Cladosporol F & $\mathrm{C}_{21} \mathrm{H}_{20} \mathrm{O}_{5}$ & 352 & {$[39,40]$} \\
\hline 127 & Cladosporol G & $\mathrm{C}_{20} \mathrm{H}_{17} \mathrm{ClO}_{6}$ & 388 & [40] \\
\hline 128 & Cladosporol G bis & $\mathrm{C}_{21} \mathrm{H}_{20} \mathrm{O}_{5}$ & 352 & {$[39]$} \\
\hline 129 & Cladosporol H & $\mathrm{C}_{20} \mathrm{H}_{16} \mathrm{O}_{5}$ & 336 & [39] \\
\hline 130 & Cladosporol I & $\mathrm{C}_{20} \mathrm{H}_{18} \mathrm{O}_{5}$ & 338 & {$[39,92]$} \\
\hline 131 & Cladosporol J & $\mathrm{C}_{20} \mathrm{H}_{18} \mathrm{O}_{5}$ & 338 & [39] \\
\hline 132 & Cladosporone A & $\mathrm{C}_{20} \mathrm{H}_{16} \mathrm{O}_{6}$ & 352 & {$[86]$} \\
\hline
\end{tabular}


Table 2. Cont.

\begin{tabular}{|c|c|c|c|c|}
\hline Code & Name & Formula & Nominal Mass (U) & Refs. \\
\hline 133 & Clindanone A & $\mathrm{C}_{22} \mathrm{H}_{18} \mathrm{O}_{7}$ & 394 & [40] \\
\hline 134 & Clindanone B & $\mathrm{C}_{22} \mathrm{H}_{18} \mathrm{O}_{7}$ & 394 & [40] \\
\hline 135 & (3R,4R)-3,4-Dihydro-3,4,8-trihydroxy-1(2H)-napthalenone & $\mathrm{C}_{10} \mathrm{H}_{10} \mathrm{O}_{4}$ & 194 & [81] \\
\hline 136 & 4,8-Dihydroxy-1-tetralone & $\mathrm{C}_{10} \mathrm{H}_{10} \mathrm{O}_{3}$ & 178 & [52] \\
\hline 137 & (3S)-3,8-Dihydroxy-6,7-dimethyl- $\alpha$-tetralone & $\mathrm{C}_{12} \mathrm{H}_{14} \mathrm{O}_{3}$ & 206 & [81] \\
\hline 138 & Isosclerone & $\mathrm{C}_{10} \mathrm{H}_{10} \mathrm{O}_{3}$ & 178 & [40] \\
\hline 139 & Scytalone & $\mathrm{C}_{10} \mathrm{H}_{10} \mathrm{O}_{4}$ & 194 & [68] \\
\hline 140 & $(-)-(4 R)$-Regiolone & $\mathrm{C}_{10} \mathrm{H}_{10} \mathrm{O}_{3}$ & 178 & [81] \\
\hline 141 & $\frac{\text { (-)-trans-(3R,4R)-3,4,8-Trihydroxy-6,7-dimethyl- }}{3,4 \text {-dihydronaphtha- len-1(2H)-one }}$ & $\mathrm{C}_{12} \mathrm{H}_{14} \mathrm{O}_{4}$ & 222 & [81] \\
\hline \multicolumn{5}{|c|}{ Naphthoquinones and anthraquinones } \\
\hline 142 & Anhydrofusarubin & $\mathrm{C}_{15} \mathrm{H}_{12} \mathrm{O}_{6}$ & 288 & [90] \\
\hline 143 & Methyl ether of fusarubin & $\mathrm{C}_{16} \mathrm{H}_{16} \mathrm{O}_{7}$ & 320 & [90] \\
\hline 144 & Plumbagin & $\mathrm{C}_{11} \mathrm{H}_{8} \mathrm{O}_{3}$ & 188 & [42] \\
\hline \multicolumn{5}{|c|}{ Perylenequinones } \\
\hline 145 & Altertoxin VIII & $\mathrm{C}_{20} \mathrm{H}_{16} \mathrm{O}_{3}$ & 304 & [87] \\
\hline 146 & Altertoxin IX & $\mathrm{C}_{20} \mathrm{H}_{18} \mathrm{O}_{2}$ & 290 & [87] \\
\hline 147 & Aterotoxin X & $\mathrm{C}_{20} \mathrm{H}_{18} \mathrm{O}_{2}$ & 290 & [87] \\
\hline 148 & Altertoxin XI & $\mathrm{C}_{21} \mathrm{H}_{20} \mathrm{O}_{2}$ & 304 & [87] \\
\hline 149 & Calphostin A (= UCN-1028A) & $\mathrm{C}_{44} \mathrm{H}_{38} \mathrm{O}_{12}$ & 758 & {$[29,30]$} \\
\hline 150 & Calphostin B & $\mathrm{C}_{37} \mathrm{H}_{34} \mathrm{O}_{11}$ & 654 & [30] \\
\hline 151 & Calphostin C (= Cladochrome E) & $\mathrm{C}_{44} \mathrm{H}_{38} \mathrm{O}_{14}$ & 790 & {$[30,31]$} \\
\hline 152 & Calphostin D (= ent-isophleinchrome) & $\mathrm{C}_{30} \mathrm{H}_{30} \mathrm{O}_{10}$ & 550 & {$[30,46]$} \\
\hline 153 & Calphostin I (= Cladochrome D) & $\mathrm{C}_{44} \mathrm{H}_{38} \mathrm{O}_{15}$ & 806 & {$[30,31]$} \\
\hline 154 & Phleichrome & $\mathrm{C}_{30} \mathrm{H}_{30} \mathrm{O}_{10}$ & 550 & {$[53,54,99]$} \\
\hline \multicolumn{5}{|c|}{ Pyrones } \\
\hline 155 & Citreoviridin A & $\mathrm{C}_{23} \mathrm{H}_{30} \mathrm{O}_{6}$ & 402 & [45] \\
\hline 156 & Herbarin A & $\mathrm{C}_{12} \mathrm{H}_{12} \mathrm{O}_{5}$ & 236 & [45] \\
\hline 157 & Herbarin B & $\mathrm{C}_{10} \mathrm{H}_{10} \mathrm{O}_{5}$ & 210 & [45] \\
\hline 158 & 5-Hydroxy-2-oxo-2H-piran-4-yl) methyl acetate & $\mathrm{C}_{8} \mathrm{H}_{8} \mathrm{O}_{5}$ & 184 & [65] \\
\hline \multicolumn{5}{|c|}{ Seco acids } \\
\hline 159 & Cladospolide E & $\mathrm{C}_{12} \mathrm{H}_{20} \mathrm{O}_{4}$ & 228 & [94] \\
\hline 160 & 11-Hydroxy-4,5-dioxododecanoic acid & $\mathrm{C}_{12} \mathrm{H}_{20} \mathrm{O}_{5}$ & 244 & [78] \\
\hline 161 & seco-Patulolide A & $\mathrm{C}_{12} \mathrm{H}_{20} \mathrm{O}_{4}$ & 228 & [94] \\
\hline 162 & seco-Patulolide C & $\mathrm{C}_{12} \mathrm{H}_{22} \mathrm{O}_{4}$ & 230 & {$[33,41,50,94]$} \\
\hline 163 & $(3 S, 5 S, 11 S)$-Trihydroxydodecanoic acid & $\mathrm{C}_{12} \mathrm{H}_{24} \mathrm{O}_{5}$ & 248 & [68] \\
\hline \multicolumn{5}{|c|}{ Sterols } \\
\hline 164 & Cladosporide A & $\mathrm{C}_{25} \mathrm{H}_{40} \mathrm{O}_{3}$ & 388 & [79] \\
\hline 165 & Cladosporide B & $\mathrm{C}_{25} \mathrm{H}_{38} \mathrm{O}_{3}$ & 386 & [80] \\
\hline 166 & Cladosporide C & $\mathrm{C}_{25} \mathrm{H}_{40} \mathrm{O}_{3}$ & 388 & [80] \\
\hline 167 & Cladosporide D & $\mathrm{C}_{25} \mathrm{H}_{38} \mathrm{O}_{3}$ & 386 & {$[80]$} \\
\hline 168 & Cladosporisteroid B & $\mathrm{C}_{21} \mathrm{H}_{30} \mathrm{O}_{3}$ & 330 & [35] \\
\hline 169 & $(22 E, 24 R)-3 \beta, 5 \alpha$-Dihydroxyergosta-7,22-dien-6-one & $\mathrm{C}_{28} \mathrm{H}_{44} \mathrm{O}_{3}$ & 428 & [35] \\
\hline 170 & Ergosterol & $\mathrm{C}_{28} \mathrm{H}_{44} \mathrm{O}$ & 396 & [79] \\
\hline 171 & $3 \alpha$-Hydroxy-pregn-7-ene-6,20-dione & $\mathrm{C}_{21} \mathrm{H}_{30} \mathrm{O}_{3}$ & 330 & {$[62]$} \\
\hline 172 & $23,24,25,26,27$-Pentanorlanost-8-ene-3 $\beta, 22$-diol & $\mathrm{C}_{28} \mathrm{H}_{42} \mathrm{O}_{5}$ & 458 & [79] \\
\hline
\end{tabular}


Table 2. Cont.

\begin{tabular}{|c|c|c|c|c|}
\hline Code & Name & Formula & Nominal Mass (U) & Refs. \\
\hline 173 & 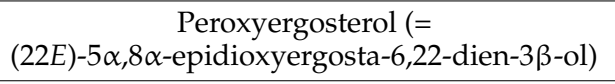 & $\mathrm{C}_{28} \mathrm{H}_{44} \mathrm{O}_{3}$ & 428 & {$[23,35,79]$} \\
\hline 174 & $3 \beta, 5 \alpha, 6 \beta$-Trihydroxyergosta-7,22-diene & $\mathrm{C}_{29} \mathrm{H}_{48} \mathrm{O}_{3}$ & 444 & [47] \\
\hline 175 & $3 \beta, 5 \alpha, 9 \alpha$-Trihydroxy-(22E,24R)-ergosta-6-one & $\mathrm{C}_{28} \mathrm{H}_{44} \mathrm{O}_{4}$ & 444 & [35] \\
\hline \multicolumn{5}{|c|}{ Tetramic acids } \\
\hline 176 & Cladodionen & $\mathrm{C}_{13} \mathrm{H}_{15} \mathrm{NO}_{3}$ & 233 & {$[58,63,89,96]$} \\
\hline 177 & Cladosin A & $\mathrm{C}_{13} \mathrm{H}_{20} \mathrm{~N}_{2} \mathrm{O}_{4}$ & 268 & [55] \\
\hline 178 & Cladosin B & $\mathrm{C}_{12} \mathrm{H}_{18} \mathrm{~N}_{2} \mathrm{O}_{4}$ & 254 & {$[55,60,63]$} \\
\hline 179 & Cladosin C & $\mathrm{C}_{12} \mathrm{H}_{16} \mathrm{~N}_{2} \mathrm{O}_{3}$ & 236 & {$[55,60,63]$} \\
\hline 180 & Cladosin D & $\mathrm{C}_{13} \mathrm{H}_{18} \mathrm{~N}_{2} \mathrm{O}_{3}$ & 250 & [55] \\
\hline 181 & Cladosin F & $\mathrm{C}_{12} \mathrm{H}_{18} \mathrm{~N}_{2} \mathrm{O}_{4}$ & 254 & {$[56,60,63]$} \\
\hline 182 & Cladosin G & $\mathrm{C}_{13} \mathrm{H}_{20} \mathrm{~N}_{2} \mathrm{O}_{4}$ & 268 & [56] \\
\hline 183 & Cladosin $\mathrm{H}$ & $\mathrm{C}_{20} \mathrm{H}_{26} \mathrm{~N}_{2} \mathrm{O}_{4}$ & 358 & [89] \\
\hline 184 & Cladosin I & $\mathrm{C}_{20} \mathrm{H}_{26} \mathrm{~N}_{2} \mathrm{O}_{4}$ & 358 & [89] \\
\hline 185 & Cladosin J & $\mathrm{C}_{25} \mathrm{H}_{29} \mathrm{~N}_{3} \mathrm{O}_{3}$ & 419 & [89] \\
\hline 186 & Cladosin K & $\mathrm{C}_{25} \mathrm{H}_{29} \mathrm{~N}_{3} \mathrm{O}_{3}$ & 419 & [89] \\
\hline 187 & Cladosin L & $\mathrm{C}_{13} \mathrm{H}_{22} \mathrm{~N}_{2} \mathrm{O}_{4}$ & 270 & [60] \\
\hline 188 & Cladosin L bis & $\mathrm{C}_{14} \mathrm{H}_{13} \mathrm{NO}_{3}$ & 243 & [63] \\
\hline 189 & Cladosin M & $\mathrm{C}_{13} \mathrm{H}_{17} \mathrm{NO}_{4}$ & 251 & [63] \\
\hline 190 & $\underline{\text { Cladosin N }}$ & $\mathrm{C}_{13} \mathrm{H}_{17} \mathrm{NO}_{4}$ & 251 & [63] \\
\hline 191 & $\underline{\text { Cladosin } \mathrm{O}}$ & $\mathrm{C}_{9} \mathrm{H}_{12} \mathrm{~N}_{2} \mathrm{O}$ & 164 & [63] \\
\hline 192 & Cladosporicin A & $\mathrm{C}_{21} \mathrm{H}_{27} \mathrm{~N}_{3} \mathrm{O}_{5}$ & 401 & [61] \\
\hline 193 & Cladosporiumin A & $\mathrm{C}_{19} \mathrm{H}_{27} \mathrm{NO}_{5}$ & 349 & [59] \\
\hline 194 & Cladosporiumin B & $\mathrm{C}_{19} \mathrm{H}_{27} \mathrm{NO}_{5}$ & 349 & [59] \\
\hline 195 & Cladosporiumin C & $\mathrm{C}_{19} \mathrm{H}_{27} \mathrm{NO}_{5}$ & 349 & [59] \\
\hline 196 & Cladosporiumin D & $\mathrm{C}_{14} \mathrm{H}_{21} \mathrm{NO}_{3}$ & 251 & [59] \\
\hline 197 & Cladosporiumin E & $\mathrm{C}_{13} \mathrm{H}_{17} \mathrm{NO}_{4}$ & 251 & {$[58,59]$} \\
\hline 198 & Cladosporiumin F & $\mathrm{C}_{13} \mathrm{H}_{19} \mathrm{NO}_{5}$ & 269 & [59] \\
\hline 199 & Cladosporiumin G & $\mathrm{C}_{13} \mathrm{H}_{19} \mathrm{NO}_{4}$ & 253 & {$[58,59]$} \\
\hline 200 & Cladosporiumin $\mathrm{H}$ & $\mathrm{C}_{14} \mathrm{H}_{23} \mathrm{NO}_{5}$ & 285 & [59] \\
\hline 201 & Cladosporiumin I & $\mathrm{C}_{13} \mathrm{H}_{19} \mathrm{NO}_{3}$ & 237 & [58] \\
\hline 202 & Cladosporiumin I bis & $\mathrm{C}_{19} \mathrm{H}_{27} \mathrm{NO}_{5}$ & 349 & [61] \\
\hline 203 & Cladosporiumin J & $\mathrm{C}_{13} \mathrm{H}_{17} \mathrm{NO}_{4}$ & 251 & [58] \\
\hline 204 & Cladosporiumin J bis & $\mathrm{C}_{19} \mathrm{H}_{27} \mathrm{NO}_{5}$ & 349 & [61] \\
\hline 205 & Cladosporiumin $\mathrm{K}$ & $\mathrm{C}_{13} \mathrm{H}_{17} \mathrm{NO}_{4}$ & 251 & [58] \\
\hline 206 & Cladosporiumin L & $\left(\mathrm{C}_{13} \mathrm{H}_{20} \mathrm{NO}_{5}\right)_{3} \mathrm{Mg}_{2}$ & 889 & [58] \\
\hline 207 & Cladosporiumin $\mathrm{M}$ & $\mathrm{C}_{13} \mathrm{H}_{15} \mathrm{NO}_{3}$ & 233 & [58] \\
\hline 208 & Cladosporiumin $\mathrm{N}$ & $\mathrm{C}_{13} \mathrm{H}_{19} \mathrm{NO}_{4}$ & 253 & [58] \\
\hline 209 & Cladosporiumin $\mathrm{O}$ & $\mathrm{C}_{13} \mathrm{H}_{17} \mathrm{NO}_{4}$ & 251 & [58] \\
\hline \multicolumn{5}{|c|}{ Tropolones } \\
\hline 210 & Malettinin A & $\mathrm{C}_{16} \mathrm{H}_{16} \mathrm{O}_{5}$ & 288 & [95] \\
\hline 211 & Malettinin B & $\mathrm{C}_{16} \mathrm{H}_{20} \mathrm{O}_{5}$ & 292 & [95] \\
\hline 212 & Malettinin C & $\mathrm{C}_{16} \mathrm{H}_{20} \mathrm{O}_{5}$ & 292 & [95] \\
\hline 213 & Malettinin E & $\mathrm{C}_{16} \mathrm{H}_{20} \mathrm{O}_{5}$ & 292 & [95] \\
\hline
\end{tabular}


Table 2. Cont.

\begin{tabular}{|c|c|c|c|c|}
\hline Code & Name & Formula & Nominal Mass (U) & Refs. \\
\hline \multicolumn{5}{|c|}{ Volatile terpenes } \\
\hline 214 & (-)-trans-Caryophyllene & $\mathrm{C}_{15} \mathrm{H}_{24}$ & 204 & [38] \\
\hline 215 & Dehydro aromdendrene & $\mathrm{C}_{15} \mathrm{H}_{22}$ & 202 & [38] \\
\hline 216 & $\alpha$-Pinene & $\mathrm{C}_{10} \mathrm{H}_{16}$ & 136 & [38] \\
\hline 217 & (+)-Sativene & $\mathrm{C}_{15} \mathrm{H}_{24}$ & 204 & [38] \\
\hline \multicolumn{5}{|c|}{ Xanthones } \\
\hline 218 & Conioxanthone A & $\mathrm{C}_{16} \mathrm{H}_{12} \mathrm{O}_{7}$ & 316 & [43] \\
\hline 219 & 3,8-Dihydroxy-6-methyl-9-oxo-9H-xanthene-1-carboxylate & $\mathrm{C}_{16} \mathrm{H}_{12} \mathrm{O}_{6}$ & 300 & [43] \\
\hline 220 & $\alpha$-Diversonolic ester & $\mathrm{C}_{16} \mathrm{H}_{16} \mathrm{O}_{7}$ & 320 & [43] \\
\hline 221 & $\beta$-Diversonolic ester & $\mathrm{C}_{16} \mathrm{H}_{16} \mathrm{O}_{7}$ & 320 & [43] \\
\hline 222 & 8-Hydroxy-6-methylxanthone-1-carboxylic acid & $\mathrm{C}_{15} \mathrm{H}_{12} \mathrm{O}_{5}$ & 272 & [43] \\
\hline 223 & $\begin{array}{l}\text { Methyl 8-hydroxy-6-(hydroxymethyl)- } \\
\text { 9-oxo-9H-xanthene-1-carboxylate }\end{array}$ & $\mathrm{C}_{16} \mathrm{H}_{12} \mathrm{O}_{6}$ & 300 & [43] \\
\hline 224 & Methyl 8-hydroxy-6-methyl-9-oxo-9H-xanthene-1- carboxylate & $\mathrm{C}_{16} \mathrm{H}_{12} \mathrm{O}_{5}$ & 284 & [43] \\
\hline 225 & $\begin{array}{l}\text { 8-(Methoxycarbonyl)-1-hydroxy-9-oxo- } \\
\text { 9H-xanthene-3-carboxylic acid }\end{array}$ & $\mathrm{C}_{16} \mathrm{H}_{10} \mathrm{O}_{7}$ & 314 & [43] \\
\hline 226 & Secalonic acid D & $\mathrm{C}_{32} \mathrm{H}_{30} \mathrm{O}_{14}$ & 638 & [85] \\
\hline 227 & Vertixanthone & $\mathrm{C}_{15} \mathrm{H}_{10} \mathrm{O}_{5}$ & 270 & [43] \\
\hline \multicolumn{5}{|c|}{ Miscellaneous } \\
\hline 228 & $\alpha$-Acetylorcinol & $\mathrm{C}_{9} \mathrm{H}_{10} \mathrm{O}_{3}$ & 166 & [52] \\
\hline 229 & Acetyl Sumiki's acid & $\mathrm{C}_{9} \mathrm{H}_{10} \mathrm{O}_{4}$ & 182 & [44] \\
\hline 230 & Cladosacid & $\mathrm{C}_{15} \mathrm{H}_{22} \mathrm{O}_{3}$ & 250 & [96] \\
\hline 231 & $\begin{array}{l}\left(2 R^{*}, 4 R^{*}\right) \text {-3,4-dihydro-5-methoxy-2-methyl-1(2H)-benzopyran-4- } \\
\text { ol }\end{array}$ & $\mathrm{C}_{10} \mathrm{H}_{12} \mathrm{O}_{2}$ & 164 & [81] \\
\hline 232 & 1-(3,5-Dihydroxy-4-methylphenyl)propan-2-one & $\mathrm{C}_{10} \mathrm{H}_{12} \mathrm{O}_{3}$ & 180 & [52] \\
\hline 233 & 1,1'-Dioxine-2,2'-dipropionic acid & $\mathrm{C}_{10} \mathrm{H}_{12} \mathrm{O}_{6}$ & 228 & [85] \\
\hline 234 & Ellagic acid & $\mathrm{C}_{14} \mathrm{H}_{6} \mathrm{O}_{8}$ & 302 & [70] \\
\hline 235 & Fonsecinone A & $\mathrm{C}_{32} \mathrm{H}_{26} \mathrm{O}_{10}$ & 570 & [47] \\
\hline 236 & 5-Hydroxy-2-methyl-4H-chromen-4-one & $\mathrm{C}_{10} \mathrm{H}_{8} \mathrm{O}_{3}$ & 176 & [83] \\
\hline 237 & (2S)-5-Hydroxy-2-methyl-chroman-4-one & $\mathrm{C}_{10} \mathrm{H}_{10} \mathrm{O}_{2}$ & 162 & {$[81,83]$} \\
\hline 238 & $\underline{4-O-\alpha-D-R i b o f u r a n o s e-2-p e n t y l-3-p h e m e t h y l o l ~}$ & $\mathrm{C}_{17} \mathrm{H}_{26} \mathrm{O}_{6}$ & 326 & [82] \\
\hline 239 & 4-O- $\alpha$-D-Ribofuranose-3-hydroxymethyl-2-pentylphenol & $\mathrm{C}_{17} \mathrm{H}_{26} \mathrm{O}_{7}$ & 342 & [81] \\
\hline 240 & Rubrofusarin B & $\mathrm{C}_{16} \mathrm{H}_{14} \mathrm{O}_{5}$ & 286 & [47] \\
\hline 241 & Sumiki's acid & $\mathrm{C}_{6} \mathrm{H}_{6} \mathrm{O}_{4}$ & 142 & [44] \\
\hline 242 & Taxol & $\mathrm{C}_{47} \mathrm{H}_{51} \mathrm{NO}_{14}$ & 853 & [51] \\
\hline 243 & tert-Butylhydroquinone & $\mathrm{C}_{10} \mathrm{H}_{14} \mathrm{O}_{2}$ & 166 & [70] \\
\hline 244 & Vermistatin & $\mathrm{C}_{18} \mathrm{H}_{16} \mathrm{O}_{6}$ & 328 & [85] \\
\hline
\end{tabular}

\subsection{Alkaloids}

Aspernigrin A (1) was originally characterized from the culture of a sponge-derived Aspergillus niger strain with its structure assigned mainly from its NMR and MS data [100], but it was structurally revised after reisolating from an endophytic strain of Cladosporium herbarum [47].

Cladosporine A (4) is the first indole diterpenoid alkaloid reported as a product of a Cladosporium strain [84]. In the class of alkaloids (Figure 2), cladosin E (3) and 2methylacetate-3,5,6-trimethylpyrazine (6) are other new natural products from strains of Cladosporium sphaerospermum [60] and an endophytic Cladosporium sp. [85]. 
<smiles>NC(=O)c1c[nH]c(Cc2ccccc2)cc1=O</smiles>

1

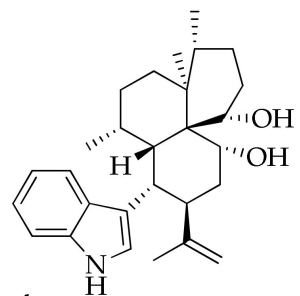

4

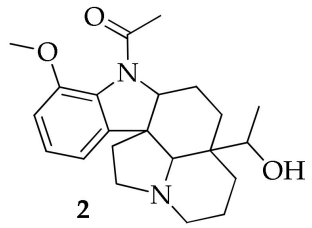

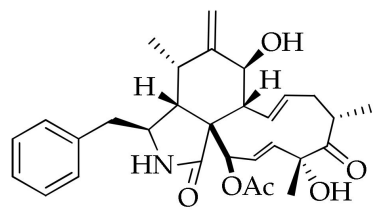

5<smiles>Cc1cccc(O)c1C(=O)N[C@H](C(=O)O)C(C)C</smiles>

3<smiles>CCCCCCCC/C=N/O</smiles>

7<smiles>CC(=O)OCc1nc(C)c(C)nc1C</smiles><smiles>CN1CCCCC1=O</smiles>

8

Figure 2. Structures of alkaloids.

\subsection{Azaphilones}

Azaphilones are a structurally variable family of fungal polyketide metabolites possessing a highly oxygentated pyranoquinone bicyclic core and a quaternary carbon center. Well-known from genera such as Aspergillus, Penicillium and Talaromyces [101,102], these compounds have also been reported from the Cladosporium species (Figure 3) [49,52]. In particular, two new azaphilones, named perangustols A and B (11,12), were isolated from a marine-derived isolate of Cladosporium perangustum together with the new natural product, bicyclic diol (9) [52].<smiles>CC1=CC2=C(CO1)C(=O)[C@@](C)(O)[C@H](O)C2</smiles>

9<smiles>CCC(C)CC(C)C(=O)OC1(C)C(=O)C=C2C=C(/C=C/C(=O)O)OC=C2C1=O</smiles>

10<smiles>CC1=CC2=CC(=O)[C@](C)(O)[C@H](O)[C@]2(C)O1</smiles>

$11(S)$

Figure 3. Structures of azaphilones.

\subsection{Benzofluorantheneones}

During a screening of microbial extracts, a series of novel reduced benzofluorantheneones (13-16) was identified in the fermentation broth of a strain of Cladosporium cladosporioides recovered from a dead insect (Figure 4) [27,28].<smiles>[R2]C1c2c(C)cccc2C2=C3CCC(=O)c4c(O)ccc(c43)C2([R])C1OC</smiles>

$13 \quad \mathrm{R}_{1}=\mathrm{H}(S)$

$15 \quad \mathrm{R}_{1}=\mathrm{H}(R)$

$16 \quad \mathrm{R}_{1}=\mathrm{H}(S)$<smiles>COC1C(=O)c2c(C)cccc2C2=C3CCC(=O)c4c(O)ccc(c43)C21</smiles>

14

Figure 4. Structures of benzofluoranthenones. 


\subsection{Benzopyrones}

A member of the benzopyrenes family named coniochaetone $\mathrm{K}(\mathbf{1 9})$ was isolated for the first time as a product of a coral symbiotic strain of Cladosporium halotolerans (Figure 5) [43]. This compound is particularly interesting because it has an uncommon carboxylic group in the backbone at position C-8'. It was identified together with the already known coniochaetones A-B $(\mathbf{1 7}, \mathbf{1 8})$ and several compounds belonging to the xanthones group. However, it must be underlined that a compound with the same name was previously characterized from a strain of Penicillium oxalicum, which differs in the absence of a carboxylic group and the presence of an additional hydroxyl group in the cyclopentane ring [103].<smiles>Cc1cc(O)c2c(=O)c3c(oc2c1)CCC3=O</smiles>

17<smiles>[R]c1cc(O)c2c(=O)c3c(oc2c1)CC[C@H]3O</smiles>

$18 \mathrm{R}=\mathrm{Me}$

$19 \mathrm{R}=\mathrm{COOH}$

Figure 5. Structures of benozopyranones.

\subsection{Binaphtopyrones}

So far, members of the family of binaphthopyrones (Figure 6) were isolated only from an extremophilic strain of $C$. cladosporioides collected from a hypersaline lake in Egypt. In particular, cladosporinone (20), together with some viriditoxin derivatives (21-23), was isolated for the first time from this strain grown in a fermentation broth fortified with $3.5 \%$ sea salt [22]. The finding of compounds with original structures from fungi in extreme habitats is not unusual, considering that these microorganisms require special survival strategies for growing and reproducing, and adaptation to such conditions requires the modification of gene regulation and metabolic pathways [104].<smiles>COC(=O)CC(O)CC1=Cc2c(-c3c(O)cc(O)c4c(O)c5c(cc34)OC(=O)C(=O)C5=O)c(OC)cc(O)c2[C@H](C(=O)OC)OC1=O</smiles>

20<smiles></smiles>

21<smiles>[R][X][H]</smiles>

Figure 6. Structures of binaphthopyrones.

\subsection{Butanolides and Butenolides}

Some metabolites from the cladospolide series are members of the family of butanolides and butenolides (Figure 7), a subgroup of lactones with a four-carbon ring structure. Many of them were isolated from several species of Cladosporium along with other cladospolides that are members of the series of macrolides [32,44,67,71,94]. 
<smiles>CC(O)CCCCCCC1OC(=O)CC1O</smiles>

24<smiles>CC(O)CCCCCC[C@H]1OC(=O)CC1O</smiles>

27<smiles>CC(=O)OC(C)CCCCCC[C@H]1OC(=O)CC1O</smiles>

25<smiles>CC(O)CCCCCCC1C=CC(=O)O1</smiles>

28<smiles>CC(O)CCCCC/C=C1/C=CC(=O)O1</smiles>

26<smiles>CC(O)CCCCC[C@H](O)C1C=CC(=O)O1</smiles>

29

Figure 7. Structures of butanolides and butenolides.

\subsection{Cinnamic acid Derivatives}

Phenylalanine and tyrosine are precursors for a wide range of natural products. Commonly in plants and fungi, a frequent step is the elimination of ammonia from the side chain to generate cinnamic acids and related compounds. Caffeic and coumaric acids are among the most common naturally occurring cinnamic acids, which can also be found in a range of esterified forms, such as quinic acid forming chlorogenic acid [105]. Caffeic, chlorogenic and coumaric acids (30-32, Figure 8) were detected in the culture extract of an endophytic strain of Cladosporium velox isolated from stem of Tinospora cordifolia. Comparative analysis of the metabolite profiles of this strain showed similar composition with stem and leaf extracts of the host plant [70].<smiles>O=C(/C=C/c1ccc(O)c(O)c1)OC1CC(O)(C(=O)O)C[C@H](O)[C@H]1O</smiles>

30<smiles>[R]c1cc(/C=C/C(=O)O)ccc1O</smiles>

$31 \mathrm{R}=\mathrm{OH}$

$32 \mathrm{R}=\mathrm{H}$

Figure 8. Structures of cinnamic acid derivatives.

\subsection{Citrinin Derivatives}

Four new compounds from a marine-derived strain of Cladosporium sp. were reported as citrinin derivatives (34-37, Figure 9) [92]. Citrinin is a polyketide mycotoxin first isolated from Penicillium citrinum [106]. Considering the existence of the name cladosporin for the product (39) since 1971 [12] and cladosporine A (4) [84], the use of the same name for this new series is questionable. Furthermore, a known citrinin dimeric derivative named citrinin H1 (33) was isolated from a strain of Cladosporium sp. [85].<smiles></smiles>

33<smiles>Cc1c(O)cc(O)c2c1[C@@H](C)[C@H](C)O[C@H]2C</smiles>

$34(R)$<smiles>Cc1c(O)cc2c3c1[C@@H](C)[C@H](C)O[C@H]3CC(=O)O2</smiles>

36<smiles>Cc1c([C@@H](C)C(C)O)cc(O)c(C=O)c1O</smiles>

37

$35(S)$

Figure 9. Structures of citrinin derivatives.

\subsection{Coumarins and Isocoumarins}

Cladosporin (39) is a member of 3,4-dihydroisocoumarins, a subgroup of isocoumarins that are commonly produced by fungi, along with coumarins [107]. Coumarins and iso- 
coumarins are structural isomers, and their general moieties are respectively characterized by a chromen-2-one and $1 \mathrm{H}$-isochromen-1-one [108]. Cladosporin was reported for the first time from mycelium of $C$. cladosporioides [12], but its absolute stereochemistry was elucidated only 17 years later using ${ }^{2} \mathrm{H}$ decoupled ${ }^{2} \mathrm{H},{ }^{13} \mathrm{C}$ NMR shift correlation [36]. Cladosporin has also been isolated from the culture filtrate of another strain of $C$. cladosporioides together with its epimer in C-6 named isocladosporin (42, Figure 10) [24,37]. It must be noted that 39 was later found from Aspergillus flavus [97] and an unidentified Aspergillus strain [109], but it was wrongly reported as a new compound with the name asperentin. As a consequence, some of its analogues were characterized as asperentin-8-methyl ether (38) and 5'-hydroxyasperentin (40) [25].

Kotanin (43) and orlandin (44) are two closely related dimeric coumarins produced by an endophytic strain of $C$. herbarum isolated from the leaves of Cynodon dactylon [47], which were previously reported as products of plant-associated Aspergillus strains [110,111].

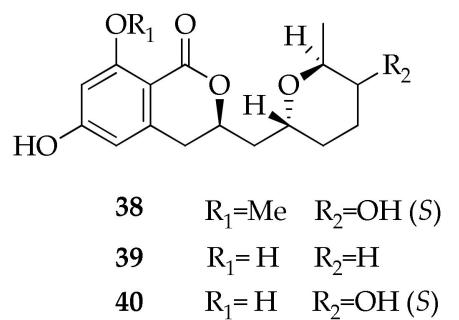<smiles>[R]Oc1cc(C)c2c(OC)cc(=O)oc2c1-c1c(O[R])cc(C)c2c(OC)cc(=O)oc12</smiles><smiles>COc1cc(=O)oc2cc(O)cc(C)c12</smiles>

41<smiles>O=C1OC(C(=O)O)Cc2cccc(O)c21</smiles>

45<smiles>C[C@H]1CCC[C@@H](C[C@@H]2Cc3cc(O)cc(O)c3C(=O)O2)O1</smiles>

42<smiles>O=c1ccc2ccc(O)cc2o1</smiles>

46

Figure 10. Structures of coumarins and isocoumarins.

\subsection{Cyclohexene Derivatives}

Four new cyclohexene derivatives named cladoscyclitols A-D (47-50) were obtained from the culture broth of a mangrove endophytic fungus Cladosporium sp. (Figure 11) [82].<smiles>CCC/C=C/C1=C(CO)C(O)[C@H](O)[C@H](O)[C@H]1O</smiles>

47<smiles>CCCCCC1=C(CO)[C@@H](O)[C@H](OC(=O)O)[C@H](O)[C@H]1O</smiles>

48<smiles>[R]C1C(O)C(CCCCC)=C(CO)[C@@H](O)[C@@H]1O</smiles>

$49 \mathrm{R}=\mathrm{H}$

$50 \quad \mathrm{R}=\mathrm{OH}(R)$

Figure 11. Structures of cyclohexene derivatives.

\subsection{Depsides}

Four new despsides (51-54) were isolated from an endophytic strain of Cladosporium uredinicola (Figure 12) [69]. The authors later revised the structures of 3-hydroxy-2,4,5trimethylphenyl 4-[(2,4-dihydroxy-3,6-dimethylbenzoyl)oxy]-2-hydroxy-3,6-dimethylbenzoate (52) and 3-hydroxy-2,5-dimethylphenyl 4-[(2,4-dihydroxy-3,6-dimethylbenzoyl)oxy]2-hydroxy-3,6-dimethylbenzoate (54) [98]. 

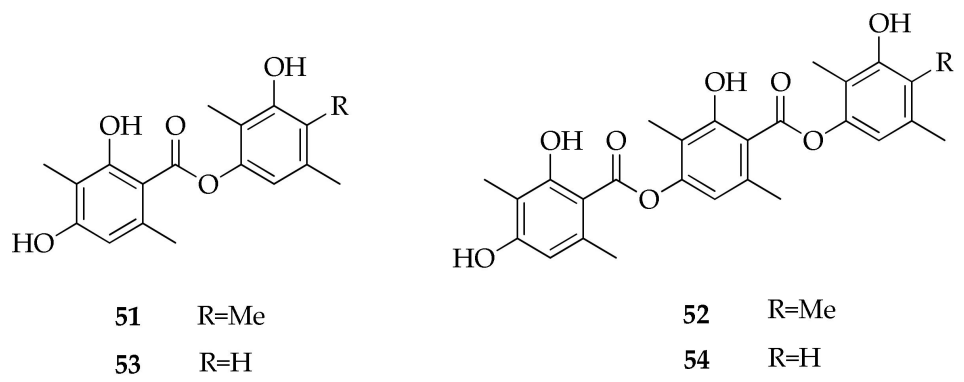

Figure 12. Structures of depsides.

\subsection{Diketopiperazines}

The diketopiperazines (55-58) reported in Figure 13 were identified via GC-MS in the crude extract of the culture filtrate of a strain of $C$. cladosporioides along with several volatile metabolites [17]. The structure of compounds in this class is based on a cyclic scaffold deriving from the condensation of two $\alpha$-amino acids.<smiles>CC(C)C[C@@H]1NC(=O)[C@H]2CCCN2C1=O</smiles>

$55(3 R, 8 R)$

$56(3 S, 8 S)$<smiles>O=C1N[C@H](Cc2ccccc2)C(=O)N2CCC[C@H]12</smiles>

$57 \quad(3 R, 8 R)$

$58 \quad(3 S, 8 S)$

Figure 13. Structures of diketopiperazines.

\subsection{Flavonoids}

The investigation of compounds produced by a previously mentioned endophytic strain of C. velox isolated from Tinospora cordifolia led to the identification, via RP-HPLC, of the known flavonenes called catechin (60) and epicatechin (61) by comparison of their retention times with those of commercially available standard compounds (Figure 14) [70].

The known (2S)-7,4'-dihydroxy-5-methoxy-8-( $\gamma, \gamma$-dimethylallyl)-flavanone (59) is a prenylated flavanone in which prenylation is represented by 3,3-dimethylallyl substituent at position $8^{\prime}[93]$.<smiles>COc1cc(O)c(CC=C(C)C)c2c1C(=O)C[C@@H](c1ccc(O)cc1)O2</smiles>

59<smiles>Oc1cc(O)c2c(c1)O[C@H](c1ccc(O)c(O)c1)[C@H](O)C2</smiles>

$60(R, S)$

$61(S, S)$

Figure 14. Structures of flavonoids.

\subsection{Gibberellins}

A strain of C. sphaerospermum from salt-stressed soybean plants was able to induce maximum plant growth in both soybean and Waito-C rice. Interestingly, high amounts of gibberellins (62-68) were detected in its culture filtrate (Figure 15) [57]. Gibberellins are diterpenoid hormones involved in many aspects of plant growth and development, hence playing a role in the mutualistic plant-endophyte interactions [112]. 

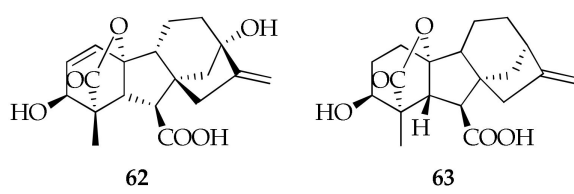

63

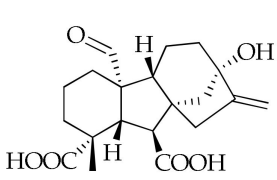

67

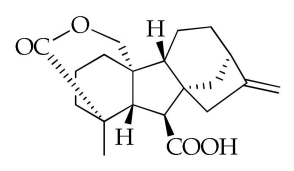

66

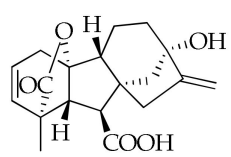

64

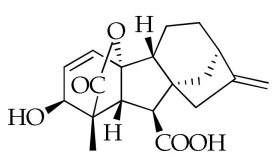

65

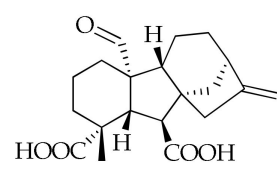

68

Figure 15. Structures of gibberellins.

\subsection{Fusicoccane Diterpene Glycosides}

Cotylenin A (69) is the major and most structurally complex metabolite of fusicoccane diterpene glycosides isolated from the Cladosporium species (Figure 16). Cotylenins A-D (69-72) are characterized by the presence of a common aglycone named cotylenol and an unusual sugar moiety consisting in a 6-O-methyl- $\alpha$-D-glucosyl derivative with an oxygenated C5-isoprene unit [72-74].
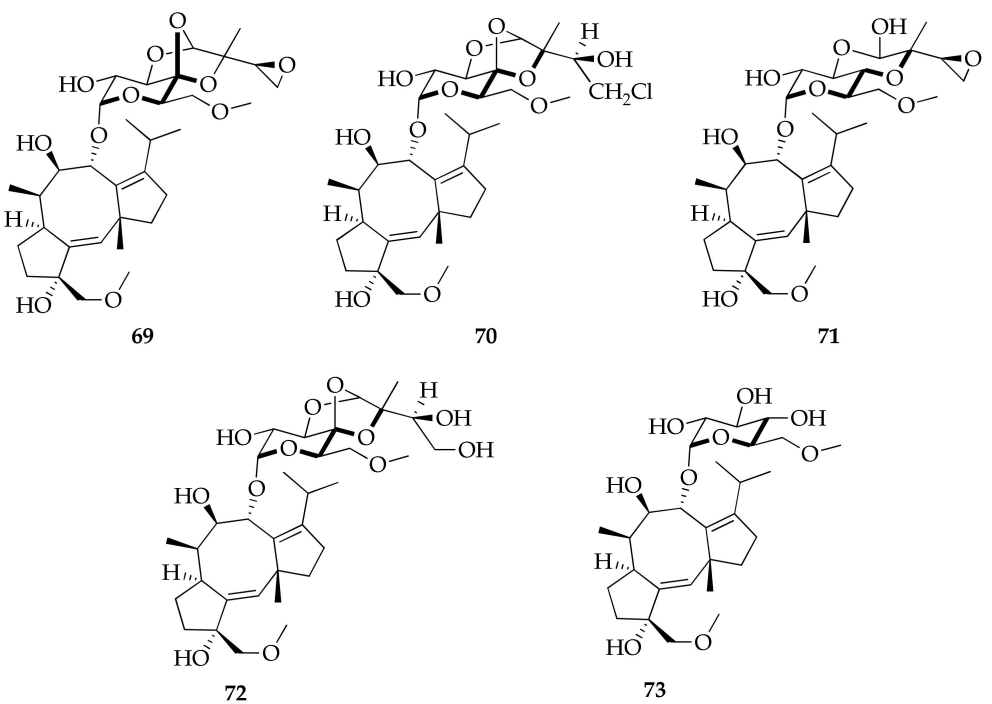

Figure 16. Structures of fusicoccane diterpene glycosides.

\subsection{Lactones}

This class includes structurally diverse compounds with a 1-oxacycloalkan-2-one structure in common. Cladosporactone A (74), cladosporimide A (75) and herbaric acid (76) are lactones isolated for the first time from a marine-derived strain of Cladosporium sp. (Figure 17) $[35,45,93]$.

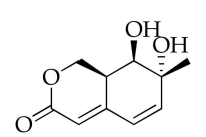

74

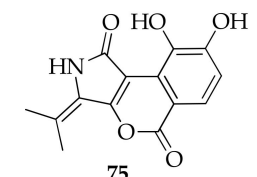

75

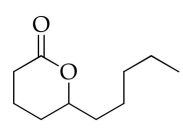<smiles>O=C(O)CC1OC(=O)c2c(O)cc(O)cc21</smiles>

77

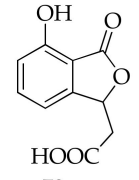

78

Figure 17. Structures of lactones. 


\subsection{Macrolides}

Macrolides are a large family of compounds characterized by a macrocyclic lactone ring. Rings are commonly 12, 14, or 16 membered [105].

Macrolides with a different number of members were also isolated from cultures of Cladosporium spp. (Figures 18 and 19), many of them reported for the first time. In fact, several 12-membered macrolides were reported from marine-derived strains of the Cladosporium species, such as recifeiolide analogues, namely $5 R$ and $5 S$-hydroxyrecifeiolides (90-91) [32] and sporiolides A and B (101-102) [88].<smiles>COC(=O)/C=C/C(O)C1CC(O)CC1/C=C/CCCC(C)OC</smiles>

79<smiles>C[C@@H]1CCCCCC(O)C(O)/C=C\C(=O)O1</smiles>

83<smiles>[R]C1CC(=O)OC(C)CCCCCC1=O</smiles>

$88 \mathrm{R}=\mathrm{OH}$

$92 \quad \mathrm{R}=\mathrm{H}$<smiles>COC(=O)CS[C@H](CC(=O)O[C@H](C)CCCCCC[C@H](C)O)C(=O)C(C)C</smiles><smiles>CC(CCCCCC(O)C(=O)O)CC(CC(=O)O)SCC(=O)O</smiles>

97<smiles>CC1CCCCCC(O)(O)C(=O)C(CC(=O)OC(=O)c2ccccc2)C1</smiles><smiles>C[C@H]1CCCCC2=C(O)C(=O)[CH]C2C1=O</smiles>

80<smiles>C[C@@H]1CCCCC[C@H](O)[C@@H](O)/C=C/C(=O)O1</smiles>

84<smiles></smiles>

81<smiles>CC1CCCCCCC(O)C(O)CC(=O)O1</smiles>

85<smiles>CC1CCCC[C@H](O)[C@H](O)/C=C/C(=O)O1</smiles>

82<smiles>[R]C(C)CCCC(=O)C([R1])CC(=O)OC([R16])C</smiles>

$86 \quad \mathrm{R}_{1}=\mathrm{OH}(R) \quad \mathrm{R}_{2}=\mathrm{H}$

$87 \quad \mathrm{R}_{1}=\mathrm{H} \quad \mathrm{R}_{2}=\mathrm{OH}(S)$<smiles>C[C@H]1C/C=C\CC[C@H](O)CCCC(=O)O1</smiles>

$90(R)$

$91(S)$

89<smiles>COc1cc(O)cc(/C=C/C[C@@H](O)C(O)C(=O)/C=C\CC(C)OC(=O)c2c(O)cc(OC)cc2O)c1</smiles><smiles>CC(CCCCC[C@@H](O)C(=O)O)CC(=O)O</smiles><smiles>CC1CCCCC[C@@H](O)C(=O)[C@H](O)CC(=O)O1</smiles><smiles>CCCCCCCC(C)OC(=O)CC(SCC(O)C(=O)OC)C(=O)O</smiles><smiles>CCCCCCCC(C)OC(=O)CC(SC1C(=O)OC(C)CCCCCC(O)C1=O)C(=O)C(O)CCCCC</smiles><smiles>CCCCCCC(=O)/C=C\C(=O)OC(C)C(C)C</smiles>

100

99<smiles>COc1cc(O)c(C(=O)OC(C)C/C=C\C(O)[C@@H](O)C[C@@H](O)C=CC=S)c(O)c1</smiles>

Figure 18. Structures of macrodiolides.

The list of macrolides from the Cladosporium species includes pandangolide $1 \mathrm{a}$ and pandangolides 1-4 (95-99). Pandangolide 1 and 2 were already known as products of an unidentified fungal species obtained from a marine sponge [113], while pandangolides 3 and 4 were identified for the first time from C. herbarum [44]. Pandangolide 1a was isolated, together with its known diastereomer 95, from a sponge-associated Cladosporium sp. [71].

The investigation of metabolites produced by the mangrove endophytic Cladosporium sp. led to the isolation of new compounds called thiocladospolides A-E (103-107, Figure 19) 
and the macrodiolide lactam derived from ornithine, called cladospamide $A(\mathbf{8 1})$, together with the known cladospolide B (83) [33,91]. This latter compound was previously isolated and identified during a screening for new plant growth regulators produced by $C$. cladosporioides, along with its isomer cladospolide A (82) [114-116]. The cladospolide series also includes the diastereomer of 82, named cladospolide C (84), which was isolated from Cladosporium tenuissimum [64].

Two new macrolides (i.e., 4-hydroxy-12-methyloxacyclododecane-2,5,6-trione (88) and 12-methyloxacyclododecane-2,5,6-trione (92)), were isolated from an endophytic strain of C. colocasiae, together with known compounds identified as cladospolide A (82), $(6 R, 12 S)-6-$ hydroxy-12-methyl-1-oxacyclododecane-2,5-dione (86), pandangolide 1 (95), patulolide B (100) and seco-patulolide C (162) [41].

An unusual macrolide with a bicyclo 5-9 ring system, named cladocladosin A (80), was isolated from the mangrove-derived endophytic fungus $C$. cladosporioides, along with two new sulfur-containing macrodiolides, namely thiocladospolides $F$ and $G(\mathbf{1 0 8 , 1 1 0})$ [34] Moreover, five new thiocladospolides were identified together with some known compounds from a strain of Cladosporium oxysporum (Figure 19) [50]. These new compounds were named thiocladospolides F-J, even if thiocladospolides F and G $(\mathbf{1 0 9}, \mathbf{1 1 1})$ had been previously reported with different structures, representing another example of the issue "one name, more structures". For this reason, these compounds are reported in Table 2 as thiocladospolides $\mathrm{F}$ bis and $\mathrm{G}$ bis.<smiles>COC(=O)[C@H](O)CS[C@H]1CC(=O)CCCCCC[C@H](C)OC1=O</smiles>

103<smiles>CC1CCCCC[C@H](O)[C@@H](O)C[C@@H](SCCO)C1=O</smiles>

107<smiles>COC(=O)C(O)CSC1CC(=O)C(=O)CCCCC[C@H](C)O1</smiles>

104<smiles>CCC[C@H](C)OC(C)=O</smiles>

108<smiles>COC(=O)CS[C@H]1CC(=O)[C@H](O)CCCCC[C@@H](C)OC1=O</smiles>

105<smiles>COC(=O)[C@H](O)CS[C@H]1C[C@H](O)[C@H](O)CCCCC[C@H](C)O1</smiles>

106<smiles>[R][C@H]1CCCCC[C@@H](C)OC(=O)[C@H](SC[C@@H](O)C(=O)O)C1</smiles><smiles>C[C@H]1CCCCC[C@@H](O)C(=O)C[C@H](SC[C@H](O)C(=O)O[C@@H](C)CCCCCC[C@H](O)/C=C/C(=O)O)C(=O)O1</smiles>

$111 \mathrm{R}=\mathrm{OH}$

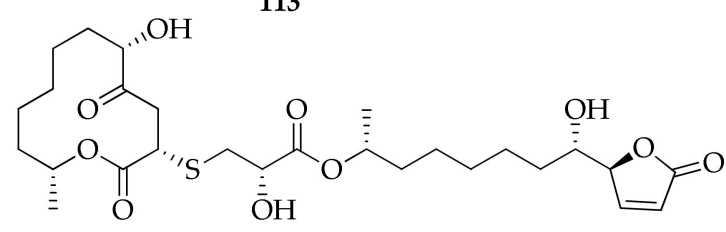

113<smiles>C[C@H](O)CCCCCC[C@@H](O)C(=O)C[C@H](S[C@H]1CC(=O)[C@H](O)CCCCC[C@H](C)OC1=O)C(=O)O</smiles>

109<smiles>COC(=O)[C@H](O)CS[C@H]1CC(=O)O[C@H](C)CCCCCC[C@@H]1O</smiles>

110

$112 \mathrm{R}=\mathrm{H}$

114

Figure 19. Structures of thiocladospolides. 


\subsection{Naphthalene Derivatives}

Two new dimeric naphthalene derivatives, named cladonaphchroms A and B (116, 117), were obtained from a mangrove-derived strain of Cladosporium sp. (Figure 20). These compounds were detected in the fungal culture extract along with some known metabolites, such as 5-hydroxy-2-methyl-4H-chromen-4-one (236), (R)-5-hydroxy-2-methyl-chroman-4-one (237), 1,8-dimethoxynaphthalene (118) and 8-methoxynaphthalen-1-ol (119) [83]. Additionally, 118 was also obtained as product of a mangrove-derived strain of Cladosporium sp. [81].<smiles>COc1cccc2c([C@@H]3C[C@H](C)Oc4cccc(O)c43)ccc(OC)c12</smiles><smiles>COc1cccc2cccc(OC)c12</smiles>

118<smiles>COc1cccc2cccc(O)c12</smiles>

119

Figure 20. Structures of naphthalene derivatives.

\subsection{Naphthalenones}

(-)-trans-(3R,4R)-3,4,8-Trihydroxy-6,7-dimethyl-3,4-dihydronaphthalen-1(2H)-one (141) is a new compound isolated from a mangrove-derived Cladosporium sp. (Figure 21), produced along with six known compounds (i.e., 118,135,137,140) [81]. Scytalone $(\mathbf{1 3 9})$ is another compound from this class, isolated from an endophytic strain of $C$. tenuissimum from Pinus wallichiana [68]. It is a polyketide known as an intermediate in melanin biosynthesis produced by many fungi associated with plants $[117,118]$.

Dimeric tetralones are a subclass of naphthalenones made from two monomers of bicyclic aromatic hydrocarbon and a ketone. A marine-derived strain of Cladosporium sp. also produces new dimeric tetralones: the newly isolated altertoxin XII (120) and the known cladosporol I (130) [87].

Among the compounds in this family, cladosporol A (121) was isolated for the first time from C. cladosporioides [26] and later on from C. tenuissimum together with some analogues, cladosporol B-E (122-125) [66]. Their absolute configurations were revised some years later from $\left(4^{\prime} R\right)$ to $\left(4^{\prime} S\right)$ when five new dimeric tetralones (i.e., cladosporols F-J) and the known cladosporol C (123) were isolated from an algal endophytic strain of C. cladosporioides [39]. Four new dimeric tetralones, namely clindanones A and B $(\mathbf{1 3 3}, \mathbf{1 3 4})$ and cladosporols $F$ and $G(\mathbf{1 2 6 , 1 2 7 )}$, were identified by a deep-sea derived strain of $C$. cladosporioides along with the known isosclerone (138), which is the only monomeric tetralone isolated from the Cladosporium species so far $[40]$. Clindanones $(\mathbf{1 3 3}, \mathbf{1 3 4})$ possess new dimeric forms of the skeleton composed by the coupling of indanone and 1-tetralone units. As introduced in chapter 2, cladosporol G (128) produced by the algal strain [39] is different from the compound (127) with the same name previously discovered as a product of the deep-sea derived strain.

Some cladosporols (i.e., 121, 123 and 124) were also isolated from a strain of Cladosporium sp. derived from the mangrove plant Kandelia candel, along with the new dimeric tetralone named cladosporone A (132) [86]. 


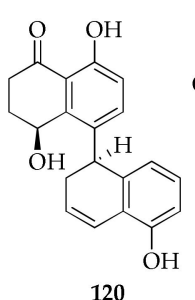<smiles>O=C1CCC(c2ccc(O)c3c2C(=O)C=CC3O)c2cccc(O)c21</smiles><smiles>O=C1CC[C@@]2(c3cccc(O)c3C1=O)c1cccc(O)c1C(=O)C2O</smiles>

122<smiles>O=C1CC[C@H](c2ccc(O)c3c2C(=O)CCC3O)c2cccc(O)c21</smiles>

123<smiles>O=C1CCC(=O)c2c1cccc2[C@H]1CCC(=O)c2c(O)cccc21</smiles>

129

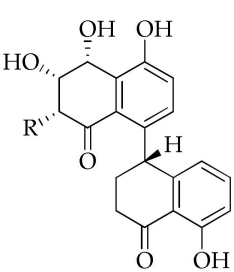

$124 \quad \mathrm{R}=\mathrm{H}$

$125 \mathrm{R}=\mathrm{OH}$

$\mathrm{O} \mathrm{OH}$

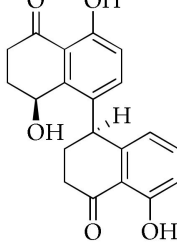

130

126

127<smiles>O=C1CC[C@H](c2ccc(O)c3c2C(=O)[C@H](O)C3=O)c2cccc(O)c21</smiles><smiles>CC(=O)[C@H](O)[C@@H]1C(=O)c2c(O)ccc(C3CCC(=O)c4c(O)cccc43)c2C1=O</smiles>

$134 \quad(R)$<smiles>[R]c1cc2c(c(O)c1[R])C(=O)CC([R3])C2[Y9]</smiles>

$135 \quad \mathrm{R}_{1}=\mathrm{H} \quad \mathrm{R}_{2}=\mathrm{H} \quad \mathrm{R}_{3}=\mathrm{OH}(R) \quad \mathrm{R}_{4}=\mathrm{OH}(R)$

$136 \quad \mathrm{R}_{1}=\mathrm{H}_{2}=\mathrm{R} \quad \mathrm{R}_{3}=\mathrm{H} \quad \mathrm{R}_{4}=\mathrm{OH}$

$137 \quad \mathrm{R}_{1}=\mathrm{Me} \mathrm{R} \mathrm{R}_{2}=\mathrm{Me} \mathrm{R} \mathrm{R}_{3}=\mathrm{OH}$ (S) $\mathrm{R}_{4}=\mathrm{H}$

$138 \quad \mathrm{R}_{1}=\mathrm{H} \quad \mathrm{R}_{2}=\mathrm{H} \quad \mathrm{R}_{3}=\mathrm{H} \quad \mathrm{R}_{4}=\mathrm{OH}(\mathrm{S})$

$139 \quad \mathrm{R}_{1}=\mathrm{OH} \quad \mathrm{R}_{2}=\mathrm{H} \quad \mathrm{R}_{3}=\mathrm{OH} \quad \mathrm{R}_{4}=\mathrm{H}$

$140 \quad \mathrm{R}_{1}=\mathrm{H} \quad \mathrm{R}_{2}=\mathrm{H} \quad \mathrm{R}_{3}=\mathrm{H} \quad \mathrm{R}_{4}=\mathrm{OH}(S)$

$141 \quad \mathrm{R}_{1}=\mathrm{Me} \mathrm{R}_{2}=\mathrm{Me} \mathrm{R}=\mathrm{OH}(R) \quad \mathrm{R}_{4}=\mathrm{OH}(R)$

Figure 21. Structures of naphthalenones.

\subsection{Naphtoquinones and Anthraquinones}

Naphthoquinones and anthraquinones have been widely identified as metabolites from various plants, microbes and marine organisms $[102,119,120]$. Two anthraquinones, namely anhydrofusarubin (142) and methyl ether of fusarubin (143), were isolated from Cladosporium sp. from the bark of the plant Rauwolfia serpentina [90]. The only naphthoquinone known from Cladosporium, plumbagin (144), was isolated from a strain of Cladosporium delicatulum, which resulted as the most potent producer of this valuable drug after a dedicated screening of endophytic fungi carried out to find strains able to synthesize this valuable drug (Figure 22) [42].<smiles>COC1=CC(=O)c2c(O)c3c(c(O)c2C1=O)C=C(C)OC3</smiles>

142<smiles>COC1=CC(=O)c2c(O)c3c(c(O)c2C1)COC(C)(OC)C3</smiles>

143<smiles>CC1=CC(=O)c2c(O)cccc2C1=O</smiles>

144

Figure 22. Structures of naphthoquinones and anthraquinones.

\subsection{Perylenquinones}

The first member of the family of perylenquinones (Figure 23), named phleichrome (154), was reported as a new phytotoxic compound produced by Cladosporium phlei [53,99]. The stereochemistry of phleichrome was investigated in detail in a subsequent study, which reports the conversion of $\mathbf{1 5 4}$ in isophleichrome, highlighting the similarity in behavior and physical data with another couple of fungal perylenquinones, cercosporin and isocercosporin [54]. In fact, perylenquinones show intriguing stereochemical features, such as axial chirality due to the helical shape of the constrained pentacyclic ring, combined 
with asymmetric carbons in the side chains. Even if it was indicated that phleichrome can be thermally converted in its unnatural diastereoisomer named isophleichrome [54], the production by C. cladosporioides of ent-isophleichrome (152) was reported [46]. Moreover, several esters of $\mathbf{1 5 2}$, belonging to the series of calphostins, were isolated from a strain of Cladosporium sp. Calphostin C and I $(\mathbf{1 5 1}, \mathbf{1 5 3})[30,121]$ have also been incorrectly reported as new products with the names cladochromes $\mathrm{E}$ and $\mathrm{D}$ [31]. In fact, these compounds had been previously isolated, and their physico-chemical properties investigated in the course of screening the potential inhibitors of protein kinase C (PKC) from a strain of C. cladosporioides, along with several other calphostins (149-153) [29,30]. Moreover, four new perylenquinones, altertoxins VIII-XI (145-148), were isolated from the fermentation broth of a marine-derived strain of Cladosporium sp. [87]. These new metabolites partially share structures with a series of metabolites originally isolated from the Alternaria species [122].<smiles></smiles>

145<smiles>CC1CCC2=c3c4ccc(O)c3c4C=CC=C21</smiles>

$146 \mathrm{R}=\mathrm{OH}(R)$

$147 \mathrm{R}=\mathrm{OH}(S)$

$148 \mathrm{R}=\mathrm{OMe}(R)$

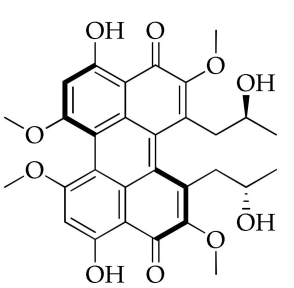

154

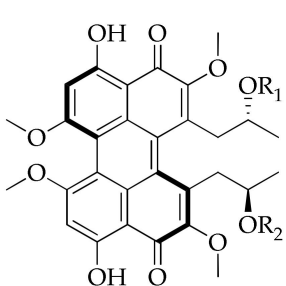

149

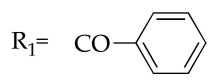

$150 \quad \mathrm{R}_{1}=\mathrm{H}$

151

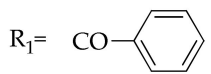

152

$\mathrm{R}_{1}=\mathrm{H}$

153

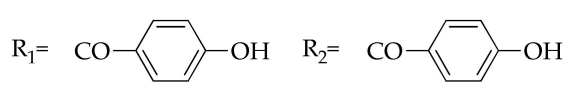

Figure 23. Structures of perylenequinones.

\subsection{Pyrones}

Pyrones represent a family of six-membered unsaturated cyclic compounds containing oxygen that naturally occurs in two isomeric forms, either as 2-pyrone or 4-pyrone. 2-pyrone is extremely prevalent in numerous natural products isolated from plants, animals, marine organisms, bacteria, fungi, and insects [123,124]. Two new 2-pyrones (i.e., herbarins A and B $(\mathbf{1 5 6 , 1 5 7 ) )}$ were obtained from a spongiculous strain of C. herbarum isolated (Figure 24) [45].<smiles></smiles><smiles>COc1cc(=O)oc(/C=C/C(=O)O)c1C</smiles>

157<smiles>COc1cc(=O)oc(/C=C/C=C/C(=O)O)c1C</smiles><smiles></smiles>

Figure 24. Structures of pyrones.

\subsection{Seco Acids}

The 12 membered seco acids reported in Figure 25 were found to be produced by strains of $C$. cladosporioides and C. tenuissimum, along with members of the families of 
lactones or macrolides $[33,67,68,94]$. It can be speculated that these compounds are intermediates in the biosynthesis of cyclic compounds because seco acids are the starting material for the production of lactones [125].<smiles>CC(O)CCCCCCC(=O)C(=O)CCC(=O)O</smiles>

159

160<smiles>C[C@H](O)CCCCCC[C@H](O)/C=C/C(=O)O</smiles>

161

162

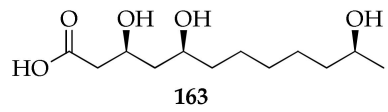

Figure 25. Structures of seco acids.

\subsection{Sterols}

Sterols are a class of lipids involved in several metabolic reactions since they are components of the membrane of eukaryotic organisms playing a crucial role in permeability and fluidity [126]. They are modified triterpenoids containing the tetracyclic ring system of lanosterol but lacking the three methyl groups at C-4 and C14. The predominant sterol found in fungi is ergosterol, which has frequently been investigated in human pathogenic fungal strains [127] Ergosterol (170) was also identified as product of a strain of Cladosporium sp., along with 23,24,25,26,27-pentanorlanost-8-ene-3 $\beta, 22$-diol (172), peroxyergosterol (173) and four new pentanorlanostane derivatives named cladosporides A-D (164-167) (Figure 26) [79,80].

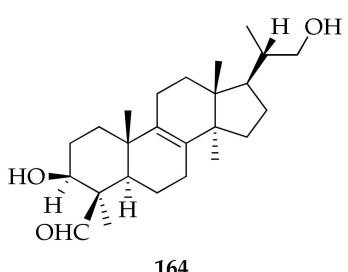

164

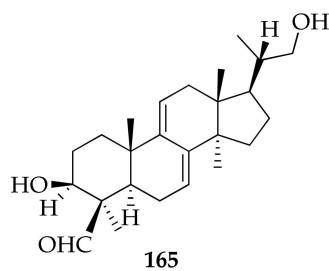

165

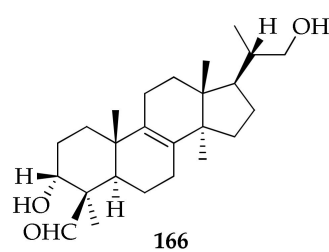

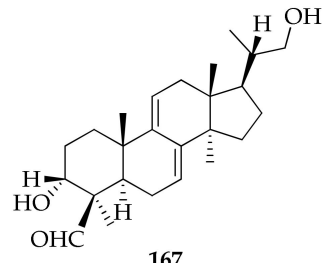<smiles>CC(=O)C1CCC2C3=CC(=O)C4C[C@@H](O)CC[C@]4(C)C3CCC12C</smiles>

168

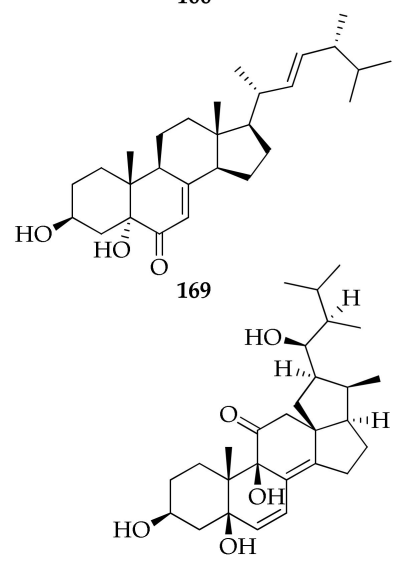

170

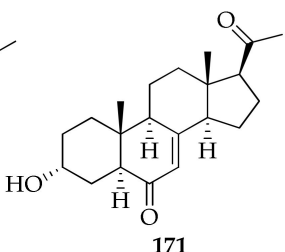

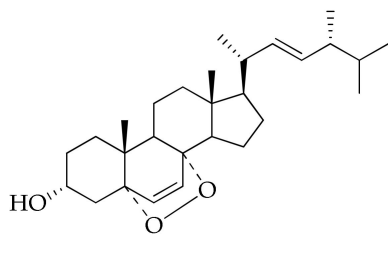

173

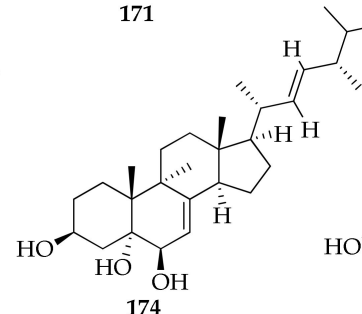

172<smiles>CC(C)C(C)C(C)C</smiles>

Figure 26. Structures of sterols. 


\subsection{Tetramic Acids}

Tetramic acids are compounds containing 2,4-pyrrolidinedione backbone obtained by the fusion of an amino acid with polyketide units. The series of cladosporimins and cladosins belong to this class, with the latter reported exclusively from C. sphaerospermum (Figures 27 and 28). In fact, six novel cladosins, the structures of which are constituted by a tetramic acid core and 6(3)-enamino-8,10-dihydroxy or 6(3)-enamino-7(8)-en-10-ol side chains, named cladosins A-D (177-180) and F-G $(\mathbf{1 8 1}, \mathbf{1 8 2})$, were reported from a strain of C. sphaerospermum from sediments collected in the Pacific Ocean $[55,56]$. Each compound exists as two tautomeric forms differing in configuration of the enamine. Moreover, investigation into the fermentation extracts of another isolate of $C$. sphaerospermum from marine sediments led to the discovery of cladosins H-K (183-186) [89]. Finally, cladosins L-O $(187,189-191)$, together with another tetramic acid named cladodionen (176), were isolated from a strain of this species obtained from healthy bulbs of Fritillaria unibracteata var. wabuensis [63].

Two structurally different compounds were reported as cladosin $\mathrm{L}(\mathbf{1 8 7 , \mathbf { 1 8 8 }})$ in two papers published almost at the same time $[60,63]$. In fact, a second product labeled with this name (188) was identified from a Hydractinia-associated strain of $C$. sphaerospermum.

Even in the cladosporiumin series (Figure 28) there are some compounds that were given the same name because of the contemporaneous publication of work dealing with the structural identification of novel tetramic acids. In fact, Liang et al. [58] and Risher et al. [61] identified two tetramic acids continuing the series of cladosporiumins (192-209), and both research teams named their new compounds cladosporiumins I and J $(201,203)$. Furthermore, cladosporiumin L (206), reported by Liang et al. [58], is a metal complex of tetramic acid. In fact, considering that the formation of metal complexes of tetramic acid derivatives (e.g., harzianic acid [128,129]) affect the chemical shifts of $\mathrm{H}-5$ an N-methyl proton or $\mathrm{NH}$, the authors can speculate that the structure of cladosporiumin $\mathrm{L}$ is a $\mathrm{Mg}_{2}$ complex. The authors also reported the structure of cladosporiumins F (198) and H (200) as their $\mathrm{Na}$ complexes.
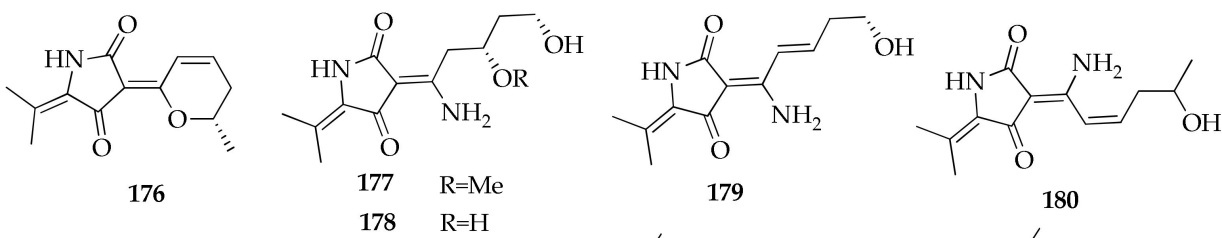<smiles>[R]OC(CCO)CC(N)=C1C(=O)NC(=C(C)C)C1=O</smiles><smiles>CO[C@@H](C/C(Nc1ccccc1)=C1/C(=O)NC(=C(C)C)C1=O)C[C@@H](C)O</smiles><smiles>CC(C)=C1NC(=O)C(=C(C[C@H](C[C@H](C)O)Nc2ccccc2)Nc2ccccc2)C1=O</smiles><smiles>CC(O)CCC(O)CC(N)=C1C(=O)NC(C(C)C)C1=O</smiles><smiles>CC(C)=C1NC(=O)C(=Cc2ccc(O)cc2)C1=O</smiles><smiles></smiles><smiles>C=C1NC(=C(C)C)C(=O)C1=CN</smiles>

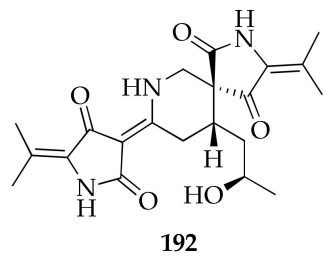

Figure 27. Structures of tetramic acids. 


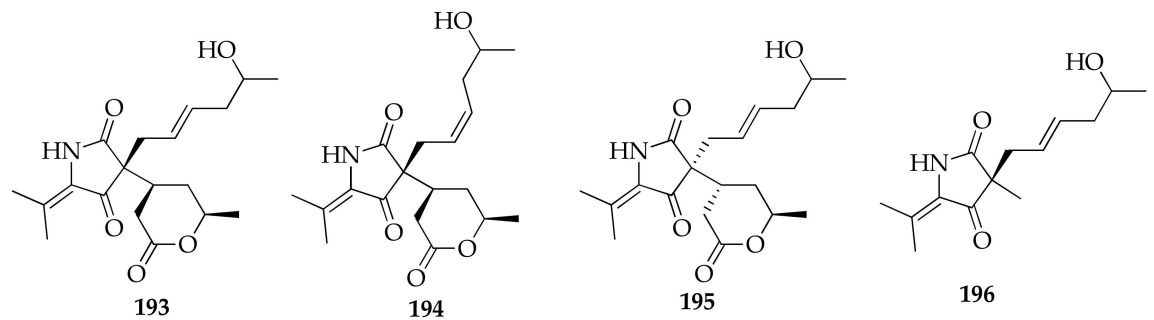<smiles>CC(C)=C1NC(=O)/C(=C(O)\C=C\CC(C)O)C1=O</smiles><smiles>CC(C)=C1NC(=O)/C(=C(/O)CC(O)CC(C)O)C1=O</smiles><smiles>CC(O)C/C=C/C(O)=C1/C(=O)N[C@H](C(C)C)C1=O</smiles><smiles>COC(CC(C)O)CC(O)C1C(=O)N[C@@H](C(C)C)C1=O</smiles>

200<smiles>CC(C)=C1NC(=O)[C@](C/C=C\C[C@H](C)O)([C@H]2CC(=O)O[C@H](C)C2)C1=O</smiles>

199<smiles>CC(C)=C1NC(=O)[C@](C/C=C\C[C@H](C)O)([C@H]2CC(=O)O[C@@H](C)C2)C1=O</smiles>
201<smiles>CC(C)=C1NC(=O)C2=C1O[C@H](C[C@H](C)O)CC2=O</smiles>

203

204<smiles>CC(C)=C1NC(=O)C2=C1O[C@H](CC(C)O)CC2=O</smiles>

205<smiles>CC(C)CC(O)CC(O)C1C(=O)NC(C)C1C(C)C</smiles>

206

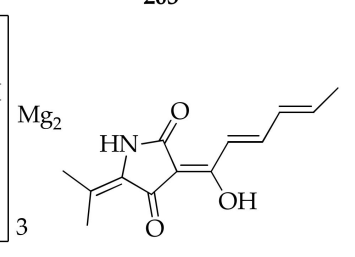

207<smiles>CC(O)C/C=C/C(O)=C1C(=O)NC(C(C)C)C1=O</smiles>

208<smiles>CC(C)=C1NC(=O)C(=C(O)/C=C/CC(C)O)C1=O</smiles>

209

Figure 28. Structures of cladosporiumins.

\subsection{Tropolones}

Malettinins A-C (210-212) were isolated and structurally elucidated from a marine strain of Cladosporium sp., along with the new malettinin E (213) (Figure 29) [95]. This represents the first isolation of tropolones from a fungus belonging to the genus Cladosporium. In fact, malettinins A-C were originally isolated from an unidentified fungus, which additionally produced a fourth metabolite, named malettinin $\mathrm{D}$. This latter compound was not identified in the culture extracts of Cladosporium sp.; instead, its new 13-epimer was detected (213).<smiles>CC1=COC2(Oc3cc(O)c(=O)cc(C)c3CC2C)C1=O</smiles>

210<smiles>Cc1cc(=O)c(O)cc2c1CC(C)[C@]1(OC[C@H](C)[C@H]1O)O2</smiles>

211<smiles>Cc1cc(=O)c(O)cc2c1CC(C)C1(OC[C@H](C)[C@H]1O)O2</smiles>

$212(R)$

$213(S)$

Figure 29. Structures of tropolones.

\subsection{Volatile Terpenes}

An isolate of $C$. cladosporioides obtained from the rhizosphere of red pepper has been investigated for the production of volatile terpenes using solid phase microextraction (SPME) coupled to GC-MS (Figure 30) [38]. Identification of volatiles revealed mainly 
(-)-trans-caryophyllene, dehydroaromadendrene, $\alpha$-pinene and (+)-sativene (214-217). In previous research on Plant Growth Promoting Rhizobacteria (PGPR) and Plant Growth Promoting Fungi (PGPF), it was reported that volatile terpenes play important chemoecological roles in the interactions between plants and their environments [130]. In fact, this strain seems to be able to improve the growth of tobacco seedlings and their root development through the production of volatile terpenes [38].

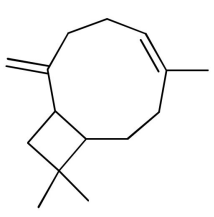

214

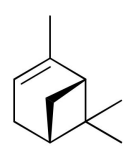

216

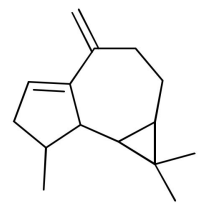

215

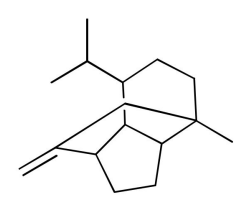

217

Figure 30. Structures of volatile terpenes.

\subsection{Xanthones}

The class of xanthones includes compounds with a backbone designated as dibenzo7-pyrone. A huge number of xanthones have been isolated from natural sources of higher plants, fungi, ferns, and lichens [131]. A strain of C. halotolerans symbiotic with the coral Porites lutea produces nine metabolites $(\mathbf{2 1 8}-\mathbf{2 2 5}, \mathbf{2 2 7})$ belonging to this class (Figure 31) [43]. Furthermore, a dimeric tetrahydroxanthone (226), where two tetrahydroxanthone monomers are connected through a 2,2'-biphenol linkage, was also isolated from an endophytic strain of Cladosporium sp. [85].<smiles>[R3]c1cc([R3])c2c(=O)c3c(O)cc([R])cc3oc2c1</smiles>

218

$$
\mathrm{R}_{1}=\mathrm{CH}_{2} \mathrm{OH} \quad \mathrm{R}_{2}=\mathrm{COOMe} \quad \mathrm{R}_{3}=\mathrm{OH}
$$$$
\mathrm{R}_{1}=\mathrm{Me} \quad \mathrm{R}_{2}=\mathrm{COOMe} \quad \mathrm{R}_{3}=\mathrm{OH}
$$

222

223

$\mathrm{R}_{1}=\mathrm{COOH} \quad \mathrm{R}_{2}=\mathrm{COOMe} \quad \mathrm{R}_{3}=\mathrm{H}$

224

225

227
$\mathrm{R}_{1}=\mathrm{CH}_{2} \mathrm{OH} \quad \mathrm{R}_{2}=\mathrm{COOMe} \quad \mathrm{R}_{3}=\mathrm{H}$

$\mathrm{R}_{1}=\mathrm{Me} \quad \mathrm{R}_{2}=\mathrm{COOMe} \quad \mathrm{R}_{3}=\mathrm{H}$

$\mathrm{R}_{1}=\mathrm{COOH} \quad \mathrm{R}_{2}=\mathrm{COOMe} \quad \mathrm{R}_{3}=\mathrm{H}$

$\mathrm{R}_{1}=\mathrm{H} \quad \mathrm{R}_{2}=$ COOMe $\quad \mathrm{R}_{3}=\mathrm{H}$<smiles>COC(=O)[C@@]1(O)CC[C@@H](O)c2c(oc3cc(C)cc(O)c3c2=O)C1</smiles>

$220 \quad(R)$

$221 \quad(S)$

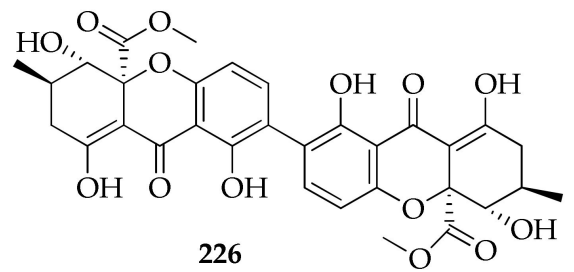

Figure 31. Structures of xanthones.

\subsection{Miscellaneous}

Finally, a number of products of Cladosporium are placed in a miscellaneous class because they have no structural affinity with previous groups (Figure 32). This is the case for a new abscisic acid analogue named cladosacid $(\mathbf{2 3 0})$ [96], sumiki's acids $(\mathbf{2 2 9}, \mathbf{2 4 1})$ [44], the new pentenoic acid derivative named $1,1^{\prime}$-dioxine-2,2' -dipropionic acid (233) [85] and two new ribofuranose phenol derivatives named 4-O- $\alpha$-D-ribofuranose-3-hydroxymethyl2-pentylphenol (239) and 4-O- $\alpha$-D-ribofuranose-2-pentyl-3-phemethylol (238) [81,82]. 


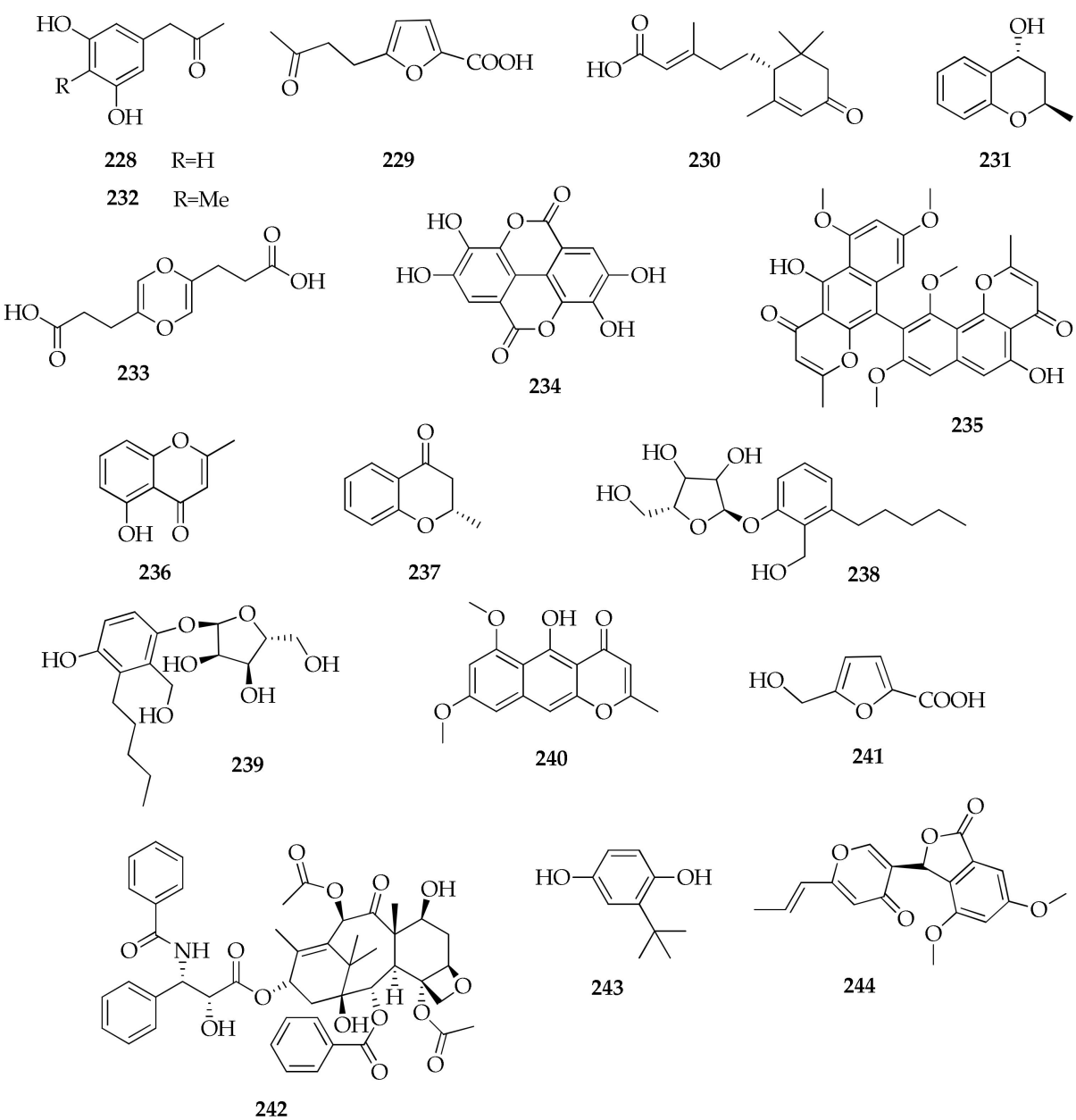

Figure 32. Structures of compounds from the group "miscellaneous".

\section{Biological Activities of Secondary Metabolites}

Most secondary metabolites reported in Table 3 have been investigated for biological properties, including antifungal, antibacterial cytotoxic and phytotoxic activities, which are summarized in Table 3. For some well-known compounds (e.g., the tetracyclic diterpenoid taxol and the funicone compound vermistatin), which have been extensively investigated and have been the subject of dedicated reviews [132], this table only considers data resulting from reports concerning the isolation of these compounds from Cladosporium strains.

Particularly valuable in the study of the bioactivities of natural products is the structureactivity relationship (SAR), but this aspect has only been taken into account in few research papers on Cladosporium compounds. An interesting evaluation of the relationships between structures and bioactivity was reported for cladosporin analogues by Wang et al. [25], who considered the presence of several essential positions in the chemical structures of these compounds that might be responsible for their antifungal activity. As a consequence, the antifungal activity of the parent compound seems to be influenced by the R configuration of C-6'. This configuration greatly decreased the antifungal activity of isocladosporin against the Colletotrichum species but slightly increased the antifungal activity against the Phomopsis species. Comparing the structures of cladosporin and 5'-hydroxyasperentin, the hydroxylation of the $\mathrm{C}^{-5^{\prime}}$ position causes the loss of the antifungal activity against the Colletotrichum species and decreases the selectivity against the Phomopsis species. Comparison of $5^{\prime}$-hydroxyasperentin and the synthesized $6,5^{\prime}$-diacetyl derivative revealed that the replacement of the hydrogen in the hydroxyl group at C-6 and the hydrogen at C-5' in the acetyl groups greatly increased selectivity toward the two Phomopsis species. Furthermore, the C-8 position also seems to be responsible for antifungal activity, demonstrated by the inactivity of asperentin-8-methyl ether against all the tested fungi [25]. 
Table 3. Bioactivities of secondary metabolites produced by the Cladosporium species.

\begin{tabular}{|c|c|c|c|c|}
\hline Name (Code) & Biological Activity & Concentration & Results & Ref. \\
\hline \multicolumn{5}{|c|}{ Alkaloids } \\
\hline Aspidospermidin-20-ol, 1-acetyl-17-methoxy (2) & Antimicrobial & $\begin{array}{l}125 \mu \mathrm{g} \mathrm{mL}^{-1} \\
62.50 \mu \mathrm{g} \mathrm{mL}^{-1} \\
320.5 \mu \mathrm{g} \mathrm{mL}^{-1}\end{array}$ & $\begin{array}{c}\text { Xanthomonas oryzae (MIC); } \\
\text { Pseudomonas syringae (MIC); } \\
\text { Aspergillus flavus (MIC) }\end{array}$ & [24] \\
\hline Cladosporine A (4) & Antimicrobial & $\begin{array}{l}4 \mu \mathrm{g} \mathrm{mL}^{-1} \\
16 \mu \mathrm{g} \mathrm{mL}^{-1}\end{array}$ & $\begin{array}{l}\text { Staphylococcus aureus (MIC); } \\
\text { Candida albicans (MIC) }\end{array}$ & [84] \\
\hline Cytochalasin D (5) & Antibacterial & $25 \mu \mathrm{g} \mathrm{mL}^{-1}$ & S. aureus (MIC) & [85] \\
\hline 2-Methylacetate-3,5,6-trimethylpyrazine (6) & Antibacterial & $12.5 \mu \mathrm{g} \mathrm{mL}^{-1}$ & S. aureus (MIC) & [85] \\
\hline \multicolumn{5}{|c|}{ Azaphilones } \\
\hline Lunatoic acid A (10) & Phytotoxic & $100 \mu \mathrm{g} \mathrm{mL} L^{-1}$ & $\begin{array}{l}\text { Brassica rapa; Sorghum durra; Brassica campestris; } \\
\text { Capsicum annuum; Raphanus sativus }\end{array}$ & [49] \\
\hline \multicolumn{5}{|c|}{ Benzofluoranthenones } \\
\hline $\begin{array}{c}\text { (6bS,7R,8S)-4,9-Dihydroxy-7,8-dimethoxy- } \\
\text { 1,6b,7,8-tetra-hydro-2H-benzo[J]fluoranthen-3-one (13) }\end{array}$ & Inhibition of anti-CD28-induced IL2 & $2.4 \mu \mathrm{M}$ & $\mathrm{IC}_{50}$ & [27] \\
\hline \multirow{2}{*}{$\begin{array}{l}\text { (6bR,7R,8S)-7-Methoxy-4,8,9-trihydroxy- } \\
\text { 1,6b,7,8-tetrahydro-2H-benzo[J]fluoranthen-3-one (15) }\end{array}$} & Inhibition of anti-CD28-induced IL2 & $2.5 \mu \mathrm{M}$ & $\mathrm{IC}_{50}$ & \multirow{2}{*}{ [27] } \\
\hline & Abl tyrosine kinase & $0.76 \mu \mathrm{M}$ & $\mathrm{IC}_{50}$ & \\
\hline $\begin{array}{c}\text { (6bS,7R,8S)-7-Methoxy-4,8,9-trihydroxy- } \\
\text { 1,6b,7,8-tetrahydro-2H-benzo[J]fluoranthen-3-one (16) }\end{array}$ & Inhibition of anti-CD28-induced IL2 & $0.4 \mu \mathrm{M}$ & $\mathrm{IC}_{50}$ & [27] \\
\hline \multicolumn{5}{|c|}{ Benzopyranones } \\
\hline Coniochaetone A (17) & Cytotoxic & $10 \mu \mathrm{M}$ & 22RV1 (67.4\%), C4-2B (13.87\%), RWPE-1 (17.3\%) & [43] \\
\hline Coniochaetone B (18) & Cytotoxic & $10 \mu \mathrm{M}$ & 22RV1 (32.7\%), C4-2B (2.9\%), RWPE-1 (19.7\%) & [43] \\
\hline Coniochaetone K (19) & Cytotoxic & $10 \mu \mathrm{M}$ & 22RV1 (64.6\%), C4-2B (7.2\%), RWPE-1 (11.7\%) & [43] \\
\hline \multicolumn{5}{|c|}{ Binaphthopyrones } \\
\hline \multirow{2}{*}{ Cladosporinone (20) } & Cytotoxic & $53.7 \mu \mathrm{M}$ & L5178Y $\left(\mathrm{IC}_{50}\right)$ & \multirow{2}{*}{ [22] } \\
\hline & Antibacterial & $64 \mu \mathrm{g} \mathrm{mL} L^{-1}$ & S. aureus (MIC) & \\
\hline \multirow{2}{*}{ Viriditoxin (21) } & Cytotoxic & $0.1 \mu \mathrm{M}$ & $\mathrm{L} 5178 \mathrm{Y}\left(\mathrm{IC}_{50}\right)$ & \multirow{2}{*}{ [22] } \\
\hline & Antibacterial & $0.015 \mu \mathrm{g} \mathrm{mL}^{-1}$ & S. aureus (MIC) & \\
\hline \multirow{2}{*}{ Viriditoxin SC-28763 (22) } & Cytotoxic & $0.25 \mu \mathrm{M}$ & L5178Y $\left(\mathrm{IC}_{50}\right)$ & \multirow{2}{*}{ [22] } \\
\hline & Antibacterial & $2 \mu \mathrm{g} \mathrm{mL}^{-1}$ & S. aureus (MIC) & \\
\hline Viriditoxin SC-30532 (23) & Antibacterial & $16 \mu \mathrm{g} \mathrm{mL}^{-1}$ & S. aureus (MIC) & [22] \\
\hline
\end{tabular}


Table 3. Cont

\begin{tabular}{|c|c|c|c|c|}
\hline Name (Code) & Biological Activity & Concentration & Results & Refs. \\
\hline \multicolumn{5}{|c|}{ Butenolides and butanolides } \\
\hline Cladospolide F (24) & Lipid accumulation & $10 \mu \mathrm{M}$ & Oleic acid & [94] \\
\hline Cladospolide G (25) & Antimicrobial & $\begin{array}{c}32 \mu \mathrm{g} \mathrm{mL}^{-1} \\
1 \mu \mathrm{g} \mathrm{mL}^{-1} \\
32 \mu \mathrm{g} \mathrm{mL}^{-1} \\
1 \mu \mathrm{g} \mathrm{mL}^{-1}\end{array}$ & $\begin{array}{c}\text { E. coli (MIC); } \\
\text { Glomerella cingulata (MIC); } \\
\text { Bipolaris sorokiniana (MIC); } \\
\text { Fusarium oxysporum f. sp. cucumerinum (MIC) }\end{array}$ & [32] \\
\hline \multirow[t]{2}{*}{ ent-Cladospolide F (27) } & Antibacterial & $\begin{array}{l}8 \mu \mathrm{g} \mathrm{mL}^{-1} \\
16 \mu \mathrm{g} \mathrm{mL}^{-1} \\
64 \mu \mathrm{g} \mathrm{mL}^{-1}\end{array}$ & $\begin{array}{c}\text { S. aureus (MIC); } \\
\text { Edwardsiella ictarda (MIC); } \\
\text { P. aeruginosa (MIC) }\end{array}$ & \multirow[t]{2}{*}{ [32] } \\
\hline & Acetylcholinesterase & $40.46 \mu \mathrm{M}$ & $\mathrm{IC}_{50}$ & \\
\hline 11-Hydroxy- $\gamma$-dodecalactone (28) & Lipid accumulation & $10 \mu \mathrm{M}$ & Oleic acid & [94] \\
\hline \multirow[b]{2}{*}{ iso-Cladospolide B (29) } & Antimicrobial & $\begin{array}{l}32 \mu \mathrm{g} \mathrm{mL}^{-1} \\
32 \mu \mathrm{g} \mathrm{mL}^{-1} \\
16 \mu \mathrm{g} \mathrm{mL} \\
64 \mu \mathrm{g} \mathrm{mL}^{-1}\end{array}$ & $\begin{array}{c}\text { E. coli (MIC); } \\
\text { Edwardsiella tarda (MIC); } \\
\text { E. ictarda (MIC); } \\
\text { G. cingulata (MIC) }\end{array}$ & [32] \\
\hline & Antimicrobial & $\begin{array}{l}16 \mu \mathrm{g} \mathrm{mL}^{-1} \\
8 \mu \mathrm{g} \mathrm{mL}^{-1} \\
8 \mu \mathrm{g} \mathrm{mL}^{-1} \\
16 \mu \mathrm{g} \mathrm{mL}^{-1} \\
32 \mu \mathrm{g} \mathrm{mL}^{-1} \\
32 \mu \mathrm{g} \mathrm{mL}^{-1}\end{array}$ & $\begin{array}{c}\text { E. tarda (MIC); } \\
\text { E. ictarda (MIC); } \\
\text { Clematis mandshurica Miura (MIC); } \\
\text { Colletotrichum gloeosporioides (MIC); } \\
\text { B. sorokiniana (MIC); } \\
\text { F. oxysporum f. sp. cucumerinum (MIC) }\end{array}$ & [50] \\
\hline \multicolumn{5}{|c|}{ Citrinin dervatives } \\
\hline Citrinin H1 (33) & Antibacterial & $\begin{array}{l}6.25 \mu \mathrm{g} \mathrm{mL}^{-1} \\
12.5 \mu \mathrm{g} \mathrm{mL}^{-1} \\
12.5 \mu \mathrm{g} \mathrm{mL}^{-1}\end{array}$ & $\begin{array}{l}\text { S. aureus (MIC); } \\
\text { E. coli (MIC); } \\
\text { B. cereus (MIC) }\end{array}$ & [85] \\
\hline Cladosporin A (34) & Toxic & $72.0 \mu \mathrm{M}$ & brine shrine nauplii $\left(\mathrm{IC}_{50}\right)$ & [92] \\
\hline Cladosporin B (35) & Toxic & $81.7 \mu \mathrm{M}$ & brine shrine nauplii $\left(\mathrm{IC}_{50}\right)$ & [92] \\
\hline Cladosporin C (36) & Toxic & $49.9 \mu \mathrm{M}$ & brine shrine nauplii $\left(\mathrm{IC}_{50}\right)$ & [92] \\
\hline \multirow{2}{*}{ Cladosporin D (37) } & Antioxidant & $16.4 \mu \mathrm{M}$ & DPPH radicals $\left(\mathrm{IC}_{50}\right)$ & \multirow{2}{*}{ [92] } \\
\hline & Toxic & $81.4 \mu \mathrm{M}$ & brine shrine nauplii $\left(\mathrm{IC}_{50}\right)$ & \\
\hline
\end{tabular}


Table 3. Cont.

\begin{tabular}{|c|c|c|c|c|}
\hline Name (Code) & Biological Activity & Concentration & Results & Refs. \\
\hline \multicolumn{5}{|c|}{ Coumarins and isocoumarins } \\
\hline \multirow{4}{*}{ Cladosporin (39) } & \multirow{3}{*}{ Antimicrobial } & $\begin{array}{l}75 \mu \mathrm{g} \mathrm{mL}^{-1} \\
40 \mu \mathrm{g} \mathrm{mL}^{-1}\end{array}$ & $\begin{array}{l}\text { dermatophytes }(100 \%) ; \\
\text { spore germination of Penicillium sp. }(100 \%) \\
\text { and Aspergillus sp. }(100 \%)\end{array}$ & [12] \\
\hline & & $30 \mu \mathrm{M}$ & $\begin{array}{c}\text { Colletotrichum acutatum }(92.7 \%), \\
\text { Colletotrichum fragariae }(90.1 \%), \\
\text { C. gloeosporioides (95.4\%), } \\
\text { Plasmopara viticola }(79.9 \%)\end{array}$ & [25] \\
\hline & & $\begin{array}{l}500 \mu \mathrm{g} \mathrm{mL}^{-1} \\
62.50 \mu \mathrm{g} \mathrm{mL}^{-1}\end{array}$ & $\begin{array}{l}\text { X. oryzae (MIC), A. flavus (MIC); } \\
\text { Fusarium solani (MIC) }\end{array}$ & [24] \\
\hline & Phytotoxic & $10^{-3} \mathrm{M}$ & etiolated wheat $(81 \%)$ & [37] \\
\hline \multirow[t]{2}{*}{$5^{\prime}$-Hydroxyasperentin (40) } & \multirow[t]{2}{*}{ Antimicrobial } & $\begin{array}{l}15.62 \mu \mathrm{g} \mathrm{mL}^{-1} \\
62.50 \mu \mathrm{g} \mathrm{mL}^{-1} \\
15.62 \mu \mathrm{g} \mathrm{mL}^{-1} \\
7.81 \mu \mathrm{g} \mathrm{mL}^{-1}\end{array}$ & $\begin{array}{l}\text { X. oryzae (MIC); } \\
\text { P. syringae (MIC); } \\
\text { A. flavus (MIC); } \\
\text { F. solani (MIC) }\end{array}$ & [24] \\
\hline & & $30 \mu \mathrm{M}$ & P. viticola $(53.9 \%)$, Phomopsis obscurans $(25.6 \%)$ & [25] \\
\hline \multirow{2}{*}{ Isocladosporin (41) } & Antimicrobial & $30 \mu \mathrm{M}$ & $\begin{array}{l}\text { C. fragariae }(50.4 \%) \\
\text { C. gloeosporioides }(60.2 \%), \\
\text { P. viticola }(83.0 \%)\end{array}$ & [25] \\
\hline & Phytotoxic & $10^{-3} \mathrm{M}$ & etiolated wheat $(100 \%)$ & [37] \\
\hline \multicolumn{5}{|c|}{ Cyclohexene derivatives } \\
\hline Cladoscyclitol B (48) & Inhibition of $\alpha$-glucosidase & $2.95 \mu \mathrm{M}$ & $\mathrm{IC}_{50}$ & [82] \\
\hline \multicolumn{5}{|c|}{ Depsides } \\
\hline $\begin{array}{l}\text { 3-Hydroxy-2,4,5-trimethylphenyl 4-[(2,4-dihydroxy-3,6- } \\
\text { dimethylbenzoyl)oxy]-2-hydroxy-3,6-dimethylbenzoate (51) }\end{array}$ & Antimicrobial & $\begin{array}{l}25 \mu \mathrm{g} \mathrm{mL}^{-1} \\
25 \mu \mathrm{g} \mathrm{mL}^{-1} \\
250 \mu \mathrm{g} \mathrm{mL}^{-1} \\
250 \mu \mathrm{g} \mathrm{mL}^{-1}\end{array}$ & $\begin{array}{l}\text { B. subtilis (bacteriostatic); } \\
\text { P. aeruginosa (bacteriostatic); } \\
\text { E. coli (bacteriostatic); } \\
\text { S. aureus (bacteriostatic) }\end{array}$ & {$[69,98]$} \\
\hline 3-Hydroxy-2,5-dimethylphenyl 2,4-dihydroxy-3,6-dimethylbenzoate (53) & Antimicrobial & $\begin{array}{l}25 \mu \mathrm{g} \mathrm{mL}^{-1} \\
25 \mu \mathrm{g} \mathrm{mL}^{-1} \\
250 \mu \mathrm{g} \mathrm{mL}^{-1} \\
250 \mu \mathrm{g} \mathrm{mL}^{-1}\end{array}$ & $\begin{array}{l}\text { B. subtilis (MIC); } \\
\text { P. aeruginosa (MIC); } \\
\text { E. coli (MIC); } \\
\text { S. aureus (MIC) }\end{array}$ & {$[69,98]$} \\
\hline
\end{tabular}


Table 3. Cont

\begin{tabular}{|c|c|c|c|c|}
\hline Name (Code) & Biological Activity & Concentration & Results & Refs. \\
\hline $\begin{array}{l}\text { 3-Hydroxy-2,5-dimethylphenyl 4-[(2,4-dihydroxy-3,6- } \\
\text { dimethylbenzoyl)oxy]-2-hydroxy-3,6-dimethylbenzoate (54) }\end{array}$ & Antimicrobial & $\begin{array}{l}250 \mu \mathrm{g} \mathrm{mL}^{-1} \\
250 \mu \mathrm{g} \mathrm{mL}^{-1} ; \\
250 \mu \mathrm{g} \mathrm{mL}^{-1} \\
250 \mu \mathrm{g} \mathrm{mL}^{-1}\end{array}$ & $\begin{array}{l}\text { B. subtilis (bacteriostatic); } \\
\text { P. aeruginosa (bacteriostatic); } \\
\text { E. coli (bacteriostatic); } \\
\text { S. aureus (bacteriostatic) }\end{array}$ & {$[69,98]$} \\
\hline \multicolumn{5}{|c|}{ Flavonoids } \\
\hline (2S)-7,4'-Dihydroxy-5-methoxy-8-( $\gamma, \gamma$-dimethylallyl)- flavanone (59) & Enzymatic inhibitory & $\begin{array}{l}11 \mu \mathrm{M} \\
27 \mu \mathrm{M}\end{array}$ & $\begin{array}{l}\operatorname{PTP} 1 \mathrm{~B}\left(\mathrm{IC}_{50}\right) \\
\mathrm{TCPTP}\left(\mathrm{IC}_{50}\right)\end{array}$ & [93] \\
\hline \multicolumn{5}{|c|}{ Lactones } \\
\hline Cladosporamide A (75) & Enzymatic inhibitory & $\begin{array}{l}48 \mu \mathrm{M} \\
54 \mu \mathrm{M}\end{array}$ & $\begin{array}{l}\text { PTP1B }\left(\mathrm{IC}_{50}\right) \\
\text { TCPTP }\left(\mathrm{IC}_{50}\right)\end{array}$ & [93] \\
\hline \multicolumn{5}{|c|}{ Macrolides } \\
\hline Cladocladosin A (80) & Antimicrobial & $\begin{array}{l}16 \mu \mathrm{g} \mathrm{mL}^{-1} ; \\
1 \mu \mathrm{g} \mathrm{mL}^{-1} ; \\
4 \mu \mathrm{gL}^{-1} ; \\
2 \mu \mathrm{g} \mathrm{mL}^{-1} ; \\
32 \mu \mathrm{g} \mathrm{mL}^{-1} ; \\
32 \mu \mathrm{g} \mathrm{mL}^{-1} ; \\
8 \mu \mathrm{g} \mathrm{mL}^{-1}\end{array}$ & $\begin{array}{c}\text { E. coli (MIC); } \\
\text { E. tarda (MIC); } \\
\text { P. aeruginosa (MIC); } \\
\text { Vibrio anguillarum (MIC); } \\
\text { F. oxysporium f. sp. momordicae (MIC); } \\
\text { Penicillium digitatum (MIC); } \\
\text { Harpophora maydis (MIC) }\end{array}$ & [34] \\
\hline Cladospolide B (83) & Phytotoxic & $1 \mu \mathrm{g}$ plant $^{-1}$ & Oryza sativa $(37.8 \%)$ & [64] \\
\hline $5 R$-Hydroxyrecifeiolide (90) & Antimicrobial & $32 \mu \mathrm{g} \mathrm{mL} L^{-1}$ & P. aeruginosa (MIC) & [32] \\
\hline 5S-Hydroxyrecifeiolide (91) & Antimicrobial & $16 \mu \mathrm{g} \mathrm{mL}^{-1}$ & G. cingulata (MIC) & [32] \\
\hline 5Z-7-Oxozeaenol (94) & Phytotoxic & $4.8 \mu \mathrm{g} \mathrm{mL}^{-1}$ & Amaranthus retroflexus $\left(\mathrm{IC}_{50}\right)$ & [49] \\
\hline Pandangolide 1 (95) & Antimicrobial & $\begin{array}{l}32 \mu \mathrm{g} \mathrm{mL}^{-1} \\
4 \mu \mathrm{g} \mathrm{mL}^{-1} ; \\
1 \mu \mathrm{g} \mathrm{mL}^{-1} \\
32 \mu \mathrm{g} \mathrm{mL}^{-1}\end{array}$ & $\begin{array}{l}\text { S. aureus (MIC); } \\
\text { E. ictarda (MIC); } \\
\text { G. cingulata (MIC); } \\
\text { P. aeruginosa (MIC) }\end{array}$ & [32] \\
\hline \multirow[b]{2}{*}{ Pandangolide 3 (98) } & \multirow[b]{2}{*}{ Antimicrobial } & $\begin{array}{l}2 \mu \mathrm{g} \mathrm{mL}^{-1} \\
8 \mu \mathrm{g} \mathrm{mL}^{-1}\end{array}$ & $\begin{array}{l}\text { C. gloeosporioides (MIC); } \\
\text { B. sorokiniana (MIC) }\end{array}$ & [33] \\
\hline & & $\begin{array}{l}32 \mu \mathrm{g} \mathrm{mL}^{-1} \\
32 \mu \mathrm{g} \mathrm{mL}^{-1} \\
32 \mu \mathrm{g} \mathrm{mL}^{-1} \\
16 \mu \mathrm{g} \mathrm{mL}^{-1}\end{array}$ & $\begin{array}{c}\text { E. tarda (MIC); } \\
\text { E. ictarda (MIC); } \\
\text { C. gloeosporioides (MIC); } \\
\text { F. oxysporum f. sp. cucumerinum (MIC) }\end{array}$ & [50] \\
\hline
\end{tabular}


Table 3. Cont

\begin{tabular}{|c|c|c|c|c|}
\hline Name (Code) & Biological Activity & Concentration & Results & Refs. \\
\hline \multirow[t]{2}{*}{ Sporiolide A (101) } & Antimicrobial & $\begin{array}{l}16.7 \mu \mathrm{g} \mathrm{mL}^{-1} ; \\
16.7 \mu \mathrm{g} \mathrm{mL}^{-1} ; \\
8.4 \mu \mathrm{g} \mathrm{mL}^{-1} ; \\
16.7 \mu \mathrm{g} \mathrm{mL}^{-1} \\
8.4 \mu \mathrm{g} \mathrm{mL}^{-1}\end{array}$ & $\begin{array}{c}\text { Micrococcus luteus (MIC); } \\
\text { C. albicans (MIC); } \\
\text { Cryptococcus neoformans (MIC); } \\
\text { Aspergillus niger (MIC); } \\
\text { Neurospora crassa (MIC) }\end{array}$ & \multirow[t]{2}{*}[88]{} \\
\hline & Cytotoxic & $0.13 \mu \mathrm{g} \mathrm{mL}^{-1}$ & $\mathrm{~L} 1210\left(\mathrm{IC}_{50}\right)$ & \\
\hline \multirow{2}{*}{ Sporiolide B (102) } & Antimicrobial & $16.7 \mu \mathrm{g} \mathrm{mL}^{-1}$ & M. luteus (MIC) & \multirow{2}{*}{ [88] } \\
\hline & Cytotoxic & $0.81 \mu \mathrm{g} \mathrm{mL}^{-1}$ & $\mathrm{~L} 1210\left(\mathrm{IC}_{50}\right)$ & \\
\hline \multirow{2}{*}{ Thiocladospolide A (103) } & \multirow{2}{*}{ Antimicrobial } & $\begin{array}{l}1 \mu \mathrm{g} \mathrm{mL}^{-1} \\
8 \mu \mathrm{g} \mathrm{mL}^{-1} \\
2 \mu \mathrm{g} \mathrm{mL}^{-1}\end{array}$ & $\begin{array}{c}\text { E. tarda (MIC); } \\
\text { E. ictarda (MIC); } \\
\text { C. glecosporioides (MIC) }\end{array}$ & [33] \\
\hline & & $\begin{array}{l}32 \mu \mathrm{g} \mathrm{mL}-1 \\
32 \mu \mathrm{gL}^{-1} \\
16 \mu \mathrm{g} \mathrm{mL}^{-1}\end{array}$ & $\begin{array}{c}\text { E. tarda (MIC); } \\
\text { E. ictarda (MIC); } \\
\text { C. gloeosporioides (MIC) }\end{array}$ & [50] \\
\hline Thiocladospolide B (104) & Antimicrobial & $\begin{array}{l}2 \mu \mathrm{g} \mathrm{mL}^{-1} \\
32 \mu \mathrm{g} \mathrm{mL}^{-1} \\
1 \mu \mathrm{g} \mathrm{mL}^{-1} \grave{\mathrm{u}}\end{array}$ & $\begin{array}{l}\text { C. gloeosporioides (MIC); } \\
\text { Physalospora piricola (MIC); } \\
\text { F. oxysporum (MIC) }\end{array}$ & [33] \\
\hline Thiocladospolide C (105) & Antimicrobial & $\begin{array}{l}1 \mu \mathrm{g} \mathrm{mL}^{-1} \\
32 \mu \mathrm{g} \mathrm{mL}^{-1} \\
32 \mu \mathrm{g} \mathrm{mL}^{-1}\end{array}$ & $\begin{array}{l}\text { C. gloeosporioides (MIC); } \\
\text { P. piricola (MIC); } \\
\text { F. oxysporum (MIC) }\end{array}$ & [33] \\
\hline Thiocladospolide D (106) & Antimicrobial & $\begin{array}{c}1 \mu \mathrm{g} \mathrm{mL}^{-1} \\
1 \mu \mathrm{gL} \mathrm{m}^{-1} \\
32 \mu \mathrm{g} \mathrm{mL}^{-1} \\
1 \mu \mathrm{g} \mathrm{mL}^{-1}\end{array}$ & $\begin{array}{c}\text { E. ictarda (MIC); } \\
\text { C. gloeosporioides (MIC); } \\
\text { P. piricola (MIC); } \\
\text { F. oxysporum (MIC) }\end{array}$ & [33] \\
\hline Thiocladospolide F (108) & Antimicrobial & $\begin{array}{r}16 \mu \mathrm{g} \mathrm{mL}^{-1} \\
2 \mu \mathrm{gL}^{-1} \\
2 \mu \mathrm{g} \mathrm{mL}^{-1} \\
16 \mu \mathrm{g} \mathrm{mL}^{-1} \\
16 \mu \mathrm{g} \mathrm{mL}^{-1} \\
4 \mu \mathrm{gL}^{-1}\end{array}$ & $\begin{array}{c}\text { E. coli (MIC); } \\
\text { E. tarda (MIC); } \\
\text { V. anguillarum (MIC); } \\
\text { F. oxysporium f. sp. momordicae (MIC); } \\
\text { P. digitatum (MIC); } \\
\text { H. maydis (MIC) }\end{array}$ & [34] \\
\hline Thiocladospolide F bis (109) & Antimicrobial & $\begin{array}{l}32 \mu \mathrm{g} \mathrm{mL}^{-1} \\
16 \mu \mathrm{g} \mathrm{mL}^{-1} \\
16 \mu \mathrm{g} \mathrm{mL}^{-1}\end{array}$ & $\begin{array}{c}\text { E. tarda (MIC); } \\
\text { E. ictarda (MIC); } \\
\text { B. sorokiniana (MIC) }\end{array}$ & [50] \\
\hline
\end{tabular}


Table 3. Cont.

\begin{tabular}{|c|c|c|c|c|}
\hline Name (Code) & Biological Activity & Concentration & Results & Refs. \\
\hline Thiocladospolide G (110) & Antimicrobial & $\begin{array}{r}2 \mu \mathrm{g} \mathrm{mL}^{-1} \\
2 \mu \mathrm{g} \mathrm{mL}^{-1} \\
32 \mu \mathrm{g} \mathrm{mL} \\
32 \mu \mathrm{g} \mathrm{mL} \\
8 \mu \mathrm{g} \mathrm{mL}^{-1}\end{array}$ & $\begin{array}{c}\text { E. tarda (MIC); } \\
\text { V. anguillarum (MIC); } \\
\text { F. oxysporium f. sp. momordicae (MIC); } \\
\text { P. digitatum (MIC); } \\
\text { H. maydis (MIC) }\end{array}$ & [34] \\
\hline Thiocladospolide G bis (111) & Antimicrobial & $\begin{array}{l}4 \mu \mathrm{g} \mathrm{mL}^{-1} \\
32 \mu \mathrm{g} \mathrm{mL} \\
32 \mu \mathrm{g} \mathrm{mL}^{-1} \\
16 \mu \mathrm{g} \mathrm{mL}^{-1} \\
32 \mu \mathrm{g} \mathrm{mL}^{-1}\end{array}$ & $\begin{array}{c}\text { E. tarda (MIC); } \\
\text { E. ictarda (MIC); } \\
\text { C. mandshurica Miura (MIC); } \\
\text { C. gloeosporioides (MIC); } \\
\text { F. oxysporum f. sp. cucumerinum (MIC) }\end{array}$ & [50] \\
\hline Thiocladospolide H (112) & Antimicrobial & $\begin{array}{c}16 \mu \mathrm{g} \mathrm{mL}^{-1} \\
8 \mu \mathrm{g} \mathrm{mL}^{-1} \\
16 \mu \mathrm{g} \mathrm{mL}^{-1} \\
16 \mu \mathrm{g} \mathrm{mL}^{-1}\end{array}$ & $\begin{array}{c}\text { E. tarda (MIC); } \\
\text { E. ictarda (MIC); } \\
\text { C. gloeosporioides (MIC); } \\
\text { B. sorokiniana (MIC) }\end{array}$ & [50] \\
\hline Thiocladospolide I (113) & Antimicrobial & $\begin{array}{l}32 \mu \mathrm{g} \mathrm{mL}^{-1} \\
32 \mu \mathrm{g} \mathrm{mL}^{-1} \\
16 \mu \mathrm{g} \mathrm{mL}^{-1}\end{array}$ & $\begin{array}{c}\text { E. tarda (MIC); } \\
\text { E. ictarda (MIC); } \\
\text { F. oxysporum f. sp. cucumerinum (MIC) }\end{array}$ & [50] \\
\hline Thiocladospolide J (114) & Antimicrobial & $\begin{array}{l}16 \mu \mathrm{g} \mathrm{mL}^{-1} ; \\
16 \mu \mathrm{g} \mathrm{mL}^{-1} ; \\
16 \mu \mathrm{g} \mathrm{mL}^{-1} ; \\
16 \mu \mathrm{g} \mathrm{mL}^{-1} ; \\
32 \mu \mathrm{gL}^{-1} ; \\
16 \mu \mathrm{g} \mathrm{mL}^{-1}\end{array}$ & $\begin{array}{c}\text { E. tarda (MIC); } \\
\text { E. ictarda (MIC); } \\
\text { C. mandshurica Miura (MIC); } \\
\text { C. gloeosporioides (MIC); } \\
\text { B. sorokiniana (MIC); } \\
\text { F. oxysporum f. sp. cucumerinum (MIC) }\end{array}$ & [50] \\
\hline Zeaenol (115) & Phytotoxic & $8.16 \mu \mathrm{g} \mathrm{mL}^{-1}$ & A. retroflexus $\left(\mathrm{IC}_{50}\right)$ & [49] \\
\hline \multicolumn{5}{|c|}{ Naphthalene derivatives } \\
\hline Cladonaphchrom A (116) & Antimicrobial & $\begin{array}{l}1.25 \mathrm{\mu g} \mathrm{mL}^{-1} ; \\
2.5 \mu \mathrm{g} \mathrm{mL}^{-1} ; \\
10 \mu \mathrm{g} \mathrm{mL}^{-1} ; \\
5 \mu \mathrm{g} \mathrm{mL}^{-1} ; \\
10 \mu \mathrm{gL} \mathrm{mL}^{-1} ; \\
50 \mu \mathrm{g} \mathrm{mL}^{-1} ; \\
50 \mu \mathrm{g} \mathrm{mL}^{-1} ; \\
25 \mu \mathrm{g} \mathrm{mL}^{-1} ; \\
100 \mu \mathrm{g} \mathrm{mL}^{-1} ; \\
50 \mu \mathrm{gL}^{-1} ; \\
50 \mu \mathrm{g} \mathrm{mL}^{-1}\end{array}$ & $\begin{array}{c}\text { Scaphirhynchus albus (MIC); } \\
\text { E. coli (MIC); } \\
\text { B. subtilis (MIC); } \\
\text { Micrococcus tetragenus (MIC); } \\
\text { M. luteus (MIC); } \\
\text { Alternaria brassicicola (MIC); } \\
\text { Phytophthora parasitica var. nicotianae (MIC); } \\
\text { Colletotrichum capsici (MIC); } \\
\text { B. oryzae (MIC); } \\
\text { Diaporthe medusaea (MIC); } \\
\text { Cyanophora paradoxa (MIC) }\end{array}$ & [83] \\
\hline
\end{tabular}


Table 3. Cont

\begin{tabular}{|c|c|c|c|c|}
\hline Name (Code) & Biological Activity & Concentration & Results & Refs. \\
\hline Cladonaphchrom B (117) & Antibacterial & $\begin{array}{r}2.5 \mu \mathrm{g} \mathrm{mL}^{-1} ; \\
2.5 \mu \mathrm{g} \mathrm{mL}^{-1} ; \\
5 \mu \mathrm{g} \mathrm{mL}^{-1} ; \\
5 \mu \mathrm{g} \mathrm{mL}^{-1} ; \\
10 \mu \mathrm{g} \mathrm{mL}^{-1} ; \\
25 \mu \mathrm{g} \mathrm{m}^{-1} ; \\
50 \mu \mathrm{g} \mathrm{mL}^{-1} ; \\
25 \mu \mathrm{g} \mathrm{mL}^{-1} ; \\
100 \mu \mathrm{g} \mathrm{mL}^{-1} \\
50 \mu \mathrm{g} \mathrm{mL}^{-1}\end{array}$ & $\begin{array}{c}\text { S. albus (MIC); } \\
\text { E. coli (MIC); } \\
\text { B. subtilis (MIC); } \\
\text { M. tetragenus (MIC); } \\
\text { M. luteus (MIC); } \\
\text { A. brassicicola (MIC); } \\
\text { P. parasitica var. nicotianae (MIC); } \\
\text { C. capsici (MIC); } \\
\text { D. medusaea (MIC); } \\
\text { C. paradoxa (MIC) }\end{array}$ & [83] \\
\hline \multicolumn{5}{|c|}{ Naphtalenones } \\
\hline Altertoxin XII (120) & Quorum sensing inhibitory & $20 \mu \mathrm{g}$ well $^{-1}$ & Chromobacterium violaceum (MIC) & [87] \\
\hline \multirow{2}{*}{ Cladosporol A (121) } & Antifungal & $100 \mathrm{ppm}$ & Uromyces appendiculatus (84.2\%) & {$[66]$} \\
\hline & B-1,3-glucan biosynthesis inhibitor & $10 \mu \mathrm{g} \mathrm{ml}$ & $\mathrm{IC}_{50}$ & [26] \\
\hline Cladosporol B (122) & Antifungal & $100 \mathrm{ppm}$ & U. appendiculatus (100\%) & {$[66]$} \\
\hline \multirow{4}{*}{ Cladosporol C (123) } & Antifungal & $100 \mathrm{ppm}$ & U. appendiculatus $(77.6 \%)$ & {$[66]$} \\
\hline & Antibacterial & $\begin{array}{l}8 \mu \mathrm{g} \mathrm{mL}^{-1} \\
64 \mu \mathrm{g} \mathrm{mL}^{-1} \\
16 \mu \mathrm{g} \mathrm{mL}^{-1}\end{array}$ & $\begin{array}{c}\text { E. coli (MIC); } \\
\text { M. luteus (MIC); } \\
\text { Vibrio harveyi (MIC) }\end{array}$ & [39] \\
\hline & \multirow[t]{2}{*}{ Cytotoxic } & $\begin{array}{l}33.9 \mu \mathrm{M} ; \\
45.6 \mu \mathrm{M} ; \\
72.5 \mu \mathrm{M} ; \\
11.4 \mu \mathrm{M}\end{array}$ & $\begin{array}{c}\text { A549 }(100 \%) ; \\
\text { H1975 }(100 \%) ; \\
\text { HL60 }(100 \%) ; \\
\text { MOLT-4 }(100 \%)\end{array}$ & [86] \\
\hline & & $\begin{array}{c}14 \mu \mathrm{M} \\
4 \mu \mathrm{M}\end{array}$ & $\begin{array}{l}\text { A549 }\left(\mathrm{IC}_{50}\right) \\
\text { H446 }\left(\mathrm{IC}_{50}\right)\end{array}$ & [39] \\
\hline \multirow{2}{*}{ Cladosporol D (124) } & Antifungal & $100 \mathrm{ppm}$ & U. appendiculatus (69.4\%) & [66] \\
\hline & Anti-COX-2 & $60.2 \mu \mathrm{M}$ & $\mathrm{IC}_{50}$ & {$[86]$} \\
\hline Cladosporol E (125) & Antifungal & $100 \mathrm{ppm}$ & U. appendiculatus $(74.8 \%)$ & {$[66,85]$} \\
\hline \multirow[b]{2}{*}{ Cladosporol F (126) } & Antibacterial & $\begin{array}{l}32 \mu \mathrm{g} \mathrm{mL}^{-1} \\
64 \mu \mathrm{g} \mathrm{mL}^{-1} \\
32 \mu \mathrm{g} \mathrm{mL}^{-1}\end{array}$ & $\begin{array}{l}\text { E. coli (MIC); } \\
\text { M. luteus (MIC); } \\
\text { V. harveyi (MIC) }\end{array}$ & [39] \\
\hline & Cytotoxic & $\begin{array}{l}15 \mu \mathrm{M} ; \\
10 \mu \mathrm{M} ; \\
23 \mu \mathrm{M} ; \\
23 \mu \mathrm{M}\end{array}$ & $\begin{array}{c}\text { A549 }\left(\mathrm{IC}_{50}\right) ; \\
\text { HeLa }\left(\mathrm{IC}_{50}\right) ; \\
\text { K562 }\left(\mathrm{IC} \mathrm{C}_{50}\right) ; \\
\text { HCT-116 }\left(\mathrm{IC}_{50}\right)\end{array}$ & {$[39,40]$} \\
\hline
\end{tabular}


Table 3. Cont.

\begin{tabular}{|c|c|c|c|c|}
\hline Name (Code) & Biological Activity & Concentration & Results & Refs. \\
\hline Cladosporol G (127) & Cytotoxic & $\begin{array}{l}3.9 \mu \mathrm{M} ; \\
8.8 \mu \mathrm{M} ; \\
19.5 \mu \mathrm{M}\end{array}$ & $\begin{array}{c}\text { HeLa }\left(\mathrm{IC}_{50}\right) ; \\
\text { K562 }\left(\mathrm{IC}_{50}\right) ; \\
\text { HCT-116 }\left(\mathrm{IC}_{50}\right)\end{array}$ & [40] \\
\hline \multirow[b]{2}{*}{ Cladosporol G bis (128) } & Antibacterial & $\begin{array}{l}64 \mu \mathrm{g} \mathrm{mL}^{-1} \\
128 \mu \mathrm{g} \mathrm{mL}^{-1} \\
64 \mu \mathrm{g} \mathrm{mL}^{-1}\end{array}$ & $\begin{array}{l}\text { E. coli (MIC); } \\
\text { M. luteus (MIC); } \\
\text { V. harveyi (MIC) }\end{array}$ & \multirow[b]{2}{*}{ [39] } \\
\hline & Cytotoxic & $\begin{array}{l}13 \mu \mathrm{M} ; \\
11 \mu \mathrm{M} ; \\
10 \mu \mathrm{M} ; \\
11 \mu \mathrm{M} ; \\
14 \mu \mathrm{M} ; \\
15 \mu \mathrm{M}\end{array}$ & $\begin{array}{c}\text { A549 }\left(\mathrm{IC}_{50}\right) ; \\
\left.\text { HeLa (IC } \mathrm{IC}_{50}\right) ; \\
\text { Huh7 }\left(\mathrm{IC}_{50}\right) ; \\
\text { L02 }\left(\mathrm{IC}_{50}\right) ; \\
\text { LM3 }\left(\mathrm{IC}_{50}\right) ; \\
\text { SW1990 }\left(\mathrm{IC}_{50}\right)\end{array}$ & \\
\hline \multirow[b]{2}{*}{ Cladosporol H (129) } & Antibacterial & $\begin{array}{c}32 \mu \mathrm{g} \mathrm{mL}^{-1} \\
64 \mu \mathrm{g} \mathrm{mL}^{-1} \\
4 \mu \mathrm{g} \mathrm{mL}^{-1}\end{array}$ & $\begin{array}{l}\text { E. coli (MIC); } \\
\text { M. luteus (MIC); } \\
\text { V. harveyi (MIC) }\end{array}$ & \multirow[b]{2}{*}{ [39] } \\
\hline & Cytotoxic & $\begin{array}{l}5 \mu \mathrm{M} ; \\
10 \mu \mathrm{M} ; \\
1 \mu \mathrm{M} ; \\
4.1 \mu \mathrm{M} ; \\
10 \mu \mathrm{M} ; \\
14 \mu \mathrm{M}\end{array}$ & $\begin{array}{l}\text { A549 }\left(\mathrm{IC}_{50}\right) ; \\
\text { H446 }\left(\mathrm{IC}_{50}\right) ; \\
\text { Huh7 }\left(\mathrm{IC}_{50}\right) ; \\
\text { LM3 }\left(\mathrm{IC}_{50}\right) ; \\
\text { MCF-7 }\left(\mathrm{IC}_{50}\right) ; \\
\text { SW1990 }\left(\mathrm{IC}_{50}\right)\end{array}$ & \\
\hline \multirow[t]{2}{*}{ Cladosporol I (130) } & Antibacterial & $\begin{array}{l}64 \mu \mathrm{g} \mathrm{mL}^{-1} ; \\
64 \mu \mathrm{g} \mathrm{mL}^{-1} ; \\
16 \mu \mathrm{g} \mathrm{mL}^{-1}\end{array}$ & $\begin{array}{l}\text { E. coli (MIC); } \\
\text { M. luteus (MIC); } \\
\text { V. harveyi (MIC) }\end{array}$ & [39] \\
\hline & Cytotoxic & $10.8 \mu \mathrm{M}$ & $\mathrm{HeLa}\left(\mathrm{IC}_{50}\right)$ & \\
\hline & Antibacterial & $\begin{array}{l}16 \mu \mathrm{g} \mathrm{mL}^{-1} ; \\
64 \mu \mathrm{g} \mathrm{mL}^{-1} ; \\
32 \mu \mathrm{g} \mathrm{mL}^{-1}\end{array}$ & $\begin{array}{l}\text { E. coli (MIC); } \\
\text { M. luteus (MIC); } \\
\text { V. harveyi (MIC) }\end{array}$ & \multirow[b]{2}{*}{ [39] } \\
\hline Cladosporol J (131) & Cytotoxic & $\begin{array}{l}15 \mu \mathrm{M} ; \\
4 \mu \mathrm{M} ; \\
4.9 \mu \mathrm{M} ; \\
6.2 \mu \mathrm{M} ; \\
13 \mu \mathrm{M} ; \\
9.1 \mu \mathrm{M} ; \\
1.8 \mu \mathrm{M} ; \\
2.2 \mu \mathrm{M}\end{array}$ & 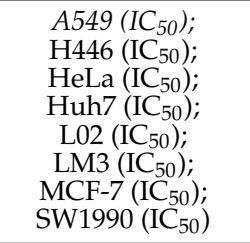 & \\
\hline
\end{tabular}


Table 3. Cont

\begin{tabular}{|c|c|c|c|c|}
\hline Name (Code) & Biological Activity & Concentration & Results & Refs. \\
\hline \multirow[t]{2}{*}{ Cladosporone A (132) } & Cytotoxic & $\begin{array}{l}14.3 \mu \mathrm{M} ; \\
15.7 \mu \mathrm{M} ; \\
29.9 \mu \mathrm{M} ; \\
40.6 \mu \mathrm{M} ; \\
21.3 \mu \mathrm{M} ; \\
10.5 \mu \mathrm{M} ; \\
17.0 \mu \mathrm{M} ; \\
10.1 \mu \mathrm{M} ; \\
53.7 \mu \mathrm{M} ; \\
14.6 \mu \mathrm{M}\end{array}$ & $\begin{array}{c}\text { K562 }(100 \%) ; \\
\text { A549 }(100 \%) ; \\
\text { Huh-7 }(100 \%) ; \\
\text { H1975 }(100 \%) ; \\
\text { MCF-7 }(100 \%): \\
\text { U937 }(100 \%) ; \\
\text { BGC823 }(100 \%) ; \\
\text { HL60 }(100 \%) ; \\
\text { HeLa }(100 \%) \\
\text { MOLT-4 }(100 \%)\end{array}$ & \multirow[t]{2}{*}{ [86] } \\
\hline & Anti-COX-2 & $49.1 \mu \mathrm{M}$ & $\mathrm{IC}_{50}$ & \\
\hline (3S)-3,8-Dihydroxy-6,7-dimethyl- $\alpha$ - tetralone (137) & Antibacterial & $20 \mu \mathrm{M}$ & $\begin{array}{l}\text { S. aureus, B. cereus, E. coli, Vibrio alginolyticus, } \\
\text { Vibrio parahemolyticus, methicillin-resistant S. aureus }\end{array}$ & [81] \\
\hline Scytalone (139) & Antibacterial & $\begin{array}{l}63.6 \mu \mathrm{g} \mathrm{mL}^{-1} \\
95.5 \mu \mathrm{g} \mathrm{mL}^{-1}\end{array}$ & $\begin{array}{l}\text { Bacillus cereus }\left(\mathrm{IC}_{50}\right) \\
\text { E. coli }\left(\mathrm{IC}_{50}\right)\end{array}$ & {$[68]$} \\
\hline \multicolumn{5}{|c|}{ Naphtoquinones and anthraquinones } \\
\hline Anhydrofusarubin (142) & Cytotoxic & $3.97 \mu \mathrm{g} \mathrm{mL}^{-1}$ & $\mathrm{~K}-562\left(\mathrm{IC}_{50}\right)$ & [90] \\
\hline \multirow[b]{2}{*}{ Methyl ether of fusarubin (143) } & Cytotoxic & $3.58 \mu \mathrm{g} \mathrm{mL}^{-1}$ & $\mathrm{~K}-562\left(\mathrm{IC}_{50}\right)$ & \multirow[b]{2}{*}{ [90] } \\
\hline & Antibacterial & $40 \mu \mathrm{g} \mathrm{disc}^{-1}$ & $\begin{array}{c}\text { S. aureus }(27 \mathrm{~mm}), \text { Bacillus megaterium }(22 \mathrm{~mm}), \\
\text { E coli }(25 \mathrm{~mm}), \text { P. aeruginosa }(24 \mathrm{~mm})\end{array}$ & \\
\hline \multicolumn{5}{|c|}{ Perylenequinones } \\
\hline Altertoxin VIII (145) & Quorum sensing inhibitory & $30 \mu \mathrm{g}$ well $^{-1}$ & C. violaceum (MIC) & [87] \\
\hline Altertoxin IX (146) & Quorum sensing inhibitory & $30 \mu \mathrm{g}$ well $^{-1}$ & C. violaceum (MIC) & [87] \\
\hline Aterotoxin X (147) & Quorum sensing inhibitory & $20 \mu \mathrm{g}$ well $^{-1}$ & C. violaceum (MIC) & [87] \\
\hline Altertoxin XI (148) & Quorum sensing inhibitory & $30 \mu \mathrm{g}$ well $^{-1}$ & C. violaceum (MIC) & [87] \\
\hline \multirow{2}{*}{ Calphostin A (=UCN-1028A) (149) } & PK inhibition & $\begin{array}{r}0.19 \mu \mathrm{g} \mathrm{mL}^{-1} \\
40 \mu \mathrm{g} \mathrm{mL}^{-1}\end{array}$ & $\begin{array}{l}\mathrm{PKC}\left(\mathrm{IC}_{50}\right) \\
\text { PKA }\left(\mathrm{IC}_{50}\right)\end{array}$ & \multirow{2}{*}[29,30]{} \\
\hline & Cytotoxic & $\begin{array}{l}0.29 \mu \mathrm{g} \mathrm{mL}^{-1} \\
0.21 \mu \mathrm{g} \mathrm{mL}^{-1}\end{array}$ & $\begin{array}{l}\text { HeLa S3 }\left(\mathrm{IC}_{50}\right) \\
\text { MCF-7 }\left(\mathrm{IC}_{50}\right)\end{array}$ & \\
\hline \multirow{2}{*}{ Calphostin B (150) } & PK inhibition & $\begin{array}{l}1.04 \mu \mathrm{g} \mathrm{mL}^{-1} \\
22.9 \mu \mathrm{g} \mathrm{mL}^{-1}\end{array}$ & $\begin{array}{l}\text { PKC }\left(\mathrm{IC}_{50}\right) \\
\text { PKA }\left(\mathrm{IC}_{50}\right)\end{array}$ & \multirow{2}{*}[7]{} \\
\hline & Cytotoxic & $\begin{array}{l}2.56 \mu \mathrm{g} \mathrm{mL}^{-1} \\
1.61 \mu \mathrm{g} \mathrm{mL}^{-1}\end{array}$ & $\begin{array}{l}\text { HeLa S3 }\left(\mathrm{IC}_{50}\right) \\
\text { MCF-7 }\left(\mathrm{IC}_{50}\right)\end{array}$ & \\
\hline
\end{tabular}


Table 3. Cont

\begin{tabular}{|c|c|c|c|c|}
\hline Name (Code) & Biological Activity & Concentration & Results & Refs. \\
\hline \multirow[b]{2}{*}{ Calphostin C (=cladochrome E) (151) } & PK inhibition & $0.05 \mu \mathrm{g} \mathrm{mL}^{-1}$ & PKC $\left(\mathrm{IC}_{50}\right)$ & \multirow[b]{2}{*}{ [30] } \\
\hline & Cytotoxic & $\begin{array}{l}0.23 \mu \mathrm{g} \mathrm{mL}^{-1} \\
0.18 \mu \mathrm{g} \mathrm{mL}^{-1}\end{array}$ & $\begin{array}{l}\text { HeLa S3 }\left(\mathrm{IC}_{50}\right) \\
\text { MCF-7 }\left(\mathrm{IC}_{50}\right)\end{array}$ & \\
\hline \multirow{4}{*}{ Calphostin D (= ent-isophleinchrome) (152) } & PK inhibition & $\begin{array}{l}6.36 \mu \mathrm{g} \mathrm{mL}^{-1} \\
12.7 \mu \mathrm{g} \mathrm{mL}^{-1}\end{array}$ & $\begin{array}{l}\text { PKC }\left(\mathrm{IC}_{50}\right) \\
\text { PKA }\left(\mathrm{IC}_{50}\right)\end{array}$ & \multirow{2}{*}{ [30] } \\
\hline & Cytotoxic & $\begin{array}{l}8.45 \mu \mathrm{g} \mathrm{mL}^{-1} \\
2.69 \mu \mathrm{g} \mathrm{mL}^{-1}\end{array}$ & $\begin{array}{l}\text { HeLa S3 }\left(\mathrm{IC}_{50}\right) \\
\text { MCF-7 }\left(\mathrm{IC}_{50}\right)\end{array}$ & \\
\hline & Phytotoxic & $5 \mu \mathrm{g} \mathrm{L}^{-1}$ & $\begin{array}{c}\text { Sugar beet cells } \\
\text { (100\% inhibition in the light, 37-64\% inhibition } \\
\text { in the dark) }\end{array}$ & [46] \\
\hline & & $33 \mu \mathrm{g} \mathrm{L}^{-1}$ & Necrosis on sugar beet leaves & \\
\hline \multirow{2}{*}{ Calphostin I (= Cladochrome D) (153) } & PK inhibition & $\begin{array}{l}6.36 \mu \mathrm{g} \mathrm{mL}^{-1} \\
12.7 \mu \mathrm{g} \mathrm{mL}^{-1}\end{array}$ & $\begin{array}{l}\text { PKC }\left(\mathrm{IC}_{50}\right) \\
\text { PKA }\left(\mathrm{IC}_{50}\right)\end{array}$ & \multirow{2}{*}[30]{} \\
\hline & Cytotoxic & $\begin{array}{l}0.24 \mu \mathrm{g} \mathrm{mL}^{-1} \\
0.16 \mu \mathrm{g} \mathrm{mL}^{-1}\end{array}$ & $\begin{array}{l}\text { HeLa S3 }\left(\mathrm{IC}_{50}\right) \\
\text { MCF-7 }\left(\mathrm{IC}_{50}\right)\end{array}$ & \\
\hline Phleichrome (154) & Invertase I inhibition & $0.5 \mathrm{mM}$ & $62 \%$ & [99] \\
\hline \multicolumn{5}{|c|}{ Seco acids } \\
\hline Seco-patulolide A (161) & Lipid accumulation & $10 \mu \mathrm{M}$ & $\begin{array}{c}\text { Oleic acid; } \\
\text { Triglycerides }\left(\sim 150 \mu \mathrm{g} \mathrm{mg}^{-1} \text { protein); }\right. \\
\text { Total cholesterol }\left(\sim 3 \mu \mathrm{g} \mathrm{mg}^{-1} \text { protein }\right)\end{array}$ & [94] \\
\hline \multirow{2}{*}{ Seco-patulolide C (162) } & Lipid accumulation & $10 \mu \mathrm{M}$ & $\begin{array}{l}\text { Oleic acid; } \\
\text { Triglycerides }\left(\sim 150 \mu \mathrm{gg} \mathrm{m}^{-1} \text { protein }\right) \\
\text { Total cholesterol }\left(\sim 3 \mu \mathrm{g} \mathrm{mg}^{-1} \text { protein }\right)\end{array}$ & [94] \\
\hline & Antimicrobial & $\begin{array}{l}32 \mu \mathrm{g} \mathrm{mL}^{-1} \\
32 \mu \mathrm{g} \mathrm{mL} \\
16 \mu \mathrm{g} \mathrm{mL}^{-1}\end{array}$ & $\begin{array}{c}\text { E. tarda (MIC); } \\
\text { E. ictarda (MIC); } \\
\text { C. gloeosporioides (MIC) }\end{array}$ & [50] \\
\hline \multirow{4}{*}{$(3 S, 5 S, 11 S)$-Trihydroxydodecanoic acid (163) } & Antibacterial & $63.6 \mu \mathrm{g} \mathrm{mL}^{-1}$ & B. cereus (MIC) & \multirow{4}{*}{ [68] } \\
\hline & Cytotoxic & $\begin{array}{l}42 \mu \mathrm{M} ; \\
82 \mu \mathrm{M}\end{array}$ & $\begin{array}{l}\text { MCF-7; } \\
\text { T47D }\end{array}$ & \\
\hline & Antibacterial & $40 \mu \mathrm{g} \operatorname{disc}^{-1}$ & $\begin{array}{l}\text { S. aureus }(27 \mathrm{~mm}), \text { B. megaterium }(22 \mathrm{~mm}), \\
\text { E coli }(25 \mathrm{~mm}), \text { P. aeruginosa }(24 \mathrm{~mm})\end{array}$ & \\
\hline & Toxic & $81.4 \mu \mathrm{M}$ & brine shrine naupalii $\left(\mathrm{IC}_{50}\right)$ & \\
\hline
\end{tabular}


Table 3. Cont

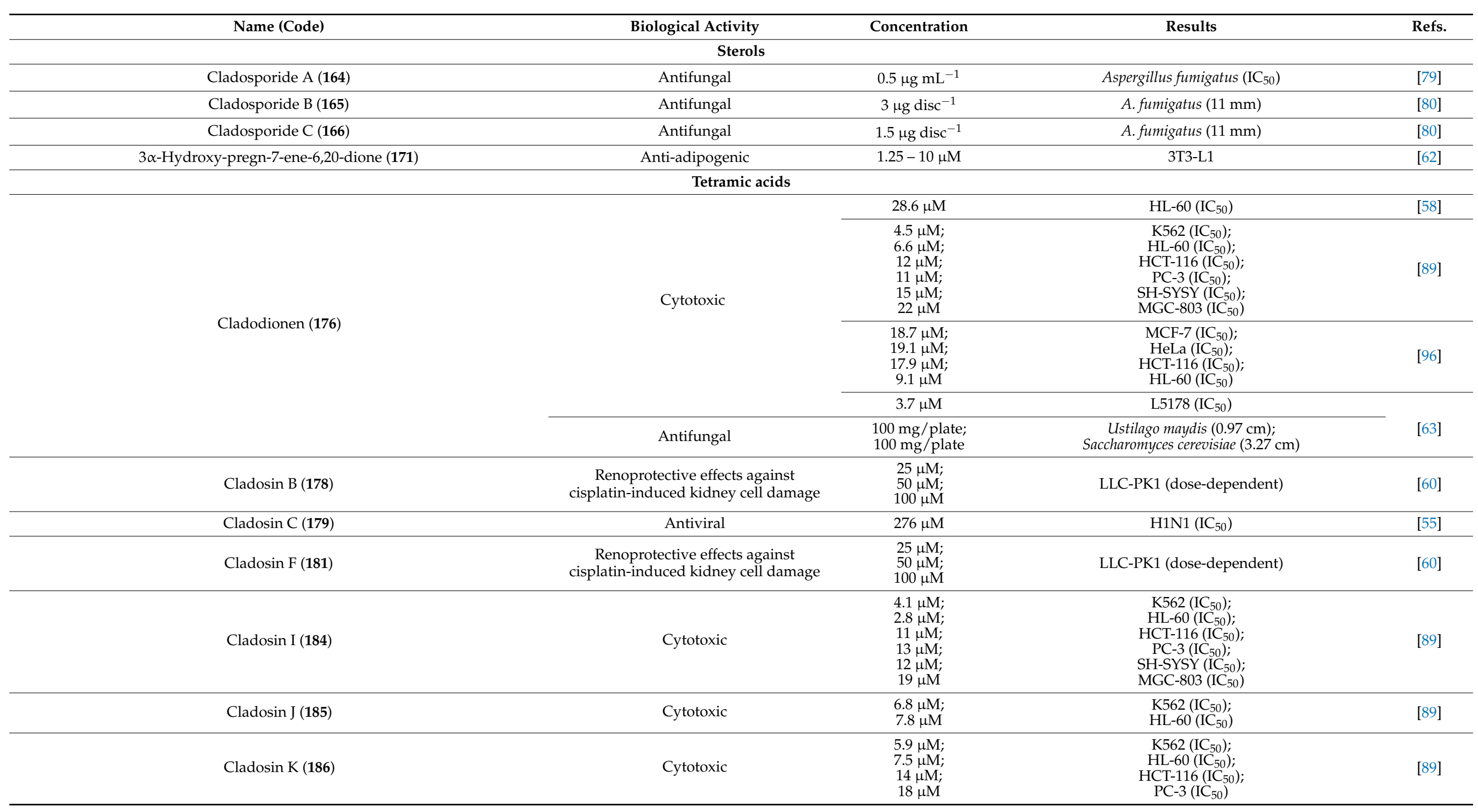


Table 3. Cont

\begin{tabular}{|c|c|c|c|c|}
\hline Name (Code) & Biological Activity & Concentration & Results & Refs. \\
\hline Cladosin L (187) & $\begin{array}{l}\text { Renoprotective effects against } \\
\text { cisplatin-induced kidney cell damage }\end{array}$ & $\begin{array}{l}25 \mu \mathrm{M} \\
50 \mu \mathrm{M} \\
100 \mu \mathrm{M}\end{array}$ & LLC-PK1 (dose-indipendent) & {$[60]$} \\
\hline Cladosin L bis (188) & Antibacterial & $\begin{array}{l}25 \mu \mathrm{M} \\
50 \mu \mathrm{M}\end{array}$ & $\begin{array}{l}\text { S. aureus ATCC } 700699\left(\mathrm{IC}_{50}\right) \text {; } \\
\text { S. aureus ATCC } 29213\left(\mathrm{IC}_{50}\right)\end{array}$ & [63] \\
\hline Cladosporicin A (192) & Cytotoxic & $\begin{array}{l}70.88 \mu \mathrm{M} ; \\
74.48 \mu \mathrm{M} ; \\
75.54 \mu \mathrm{M} ; \\
79.36 \mu \mathrm{M}\end{array}$ & $\begin{array}{c}\text { Bt549 }\left(\mathrm{IC}_{50}\right) ; \\
\left.\text { HCC70 (IC } \mathrm{IC}_{50}\right) ; \\
\left.\text { MDA-MB-231 (IC } \mathrm{IC}_{50}\right) ; \\
\text { MDA-MB-468 }\left(\mathrm{IC}_{50}\right)\end{array}$ & [61] \\
\hline Cladosporiumin J bis (204) & Cytotoxic & $\begin{array}{l}78.96 \mu \mathrm{M} ; \\
76.41 \mu \mathrm{M} ; \\
79.27 \mu \mathrm{M} ; \\
74.64 \mu \mathrm{M}\end{array}$ & $\begin{array}{c}\text { Bt549 }\left(\mathrm{IC}_{50}\right) ; \\
\text { HCC70 }\left(\mathrm{IC}_{50}\right) ; \\
\left.\text { MDA-MB-231 (IC }{ }_{50}\right) ; \\
\text { MDA-MB-468 }\left(\mathrm{IC}_{50}\right)\end{array}$ & {$[61]$} \\
\hline \multicolumn{5}{|c|}{ Tropolones } \\
\hline Malettinin A (210) & Antimicrobial & $\begin{array}{l}33.1 \mu \mathrm{M} \\
100 \mu \mathrm{M}\end{array}$ & $\begin{array}{c}\text { Trichophyton rubrum }\left(\mathrm{IC}_{50}\right) \\
\text { C. albicans }(81 \%)\end{array}$ & [95] \\
\hline Malettinin C (212) & Antimicrobial & $\begin{array}{l}37.9 \mu \mathrm{M} ; \\
83.2 \mu \mathrm{M} \\
100 \mu \mathrm{M} \\
100 \mu \mathrm{M} \\
100 \mu \mathrm{M}\end{array}$ & $\begin{array}{l}\text { X. campestris }\left(\mathrm{IC}_{50}\right) ; \\
\text { T. rubrum }\left(\mathrm{IC}_{50}\right) ; \\
\text { S. epidermidis }(<80 \%) ; \\
\text { B. subtilis }(<80 \%) ; \\
\text { C. albicans }(<80 \%)\end{array}$ & [95] \\
\hline Malettinin E (213) & Antimicrobial & $\begin{array}{l}28.7 \mu \mathrm{M} \\
30.7 \mu \mathrm{M}\end{array}$ & $\begin{array}{l}\text { X. campestris }\left(\mathrm{IC}_{50}\right) \\
\text { T. rubrum }\left(\mathrm{IC}_{50}\right)\end{array}$ & [95] \\
\hline \multicolumn{5}{|c|}{ Xanthones } \\
\hline Conioxanthone A (218) & Cytotoxic & $10 \mu \mathrm{M}$ & 22RV1 (36.8\%), C4-2B (3.3\%), RWPE-1 (20.3\%) & [43] \\
\hline 3,8-Dihydroxy-6-methyl-9-oxo-9H-xanthene-1-carboxylate (219) & Cytotoxic & $10 \mu \mathrm{M}$ & 22RV1 (82.1\%), C4-2B (77.7\%), RWPE-1 (11.5\%) & [43] \\
\hline$\alpha$-Diversonolic ester (220) & Cytotoxic & $10 \mu \mathrm{M}$ & 22RV1 (28.8\%), C4-2B (12.9\%), RWPE-1 (24.3\%) & [43] \\
\hline$\beta$-Diversonolic ester (221) & Cytotoxic & $10 \mu \mathrm{M}$ & 22RV1 (40.2\%), C4-2B (2.8\%), RWPE-1 (10.3\%) & [43] \\
\hline 8-Hydroxy-6-methylxanthone-1-carboxylic acid (222) & Cytotoxic & $10 \mu \mathrm{M}$ & 22RV1 (71.3\%), C4-2B (60.7\%), RWPE-1 (19.7\%) & [43] \\
\hline Methyl 8-hydroxy-6-(hydroxymethyl)- 9-oxo-9H-xanthene-1-carboxylate (223) & Cytotoxic & $10 \mu \mathrm{M}$ & 22RV1 (68.1\%), C4-2B (20.2\%), RWPE-1 (19.0\%) & [43] \\
\hline
\end{tabular}


Table 3. Cont

\begin{tabular}{|c|c|c|c|c|}
\hline Name (Code) & Biological Activity & Concentration & Results & Refs. \\
\hline Methyl 8-hydroxy-6-methyl-9-oxo-9H-xanthene-1-carboxylate (224) & Cytotoxic & $10 \mu \mathrm{M}$ & 22RV1 (55.8\%), C4-2B (8.1\%), RWPE-1 (5.3\%) & [43] \\
\hline 8-(Methoxycarbonyl)-1-hydroxy-9-oxo-9H-xanthene-3-carboxylic acid (225) & Cytotoxic & $10 \mu \mathrm{M}$ & 22RV1 (63.9\%), C4-2B (12.2\%), RWPE-1 (27.0\%) & [43] \\
\hline Vertixanthone (227) & Cytotoxic & $10 \mu \mathrm{M}$ & 22RV1 (27.1\%), RWPE-1 (25.0\%) & [43] \\
\hline \multicolumn{5}{|c|}{ Miscellaneous } \\
\hline Acetyl Sumiki's acid (229) & Antibacterial & $5 \mu \mathrm{g} \operatorname{disc}^{-1}$ & B. subtilis $(7 \mathrm{~mm})$, S. aureus $(7 \mathrm{~mm})$ & [44] \\
\hline 1,1'-Dioxine-2,2'-dipropionic acid (233) & Antibacterial & $\begin{array}{c}25 \mu \mathrm{g} \mathrm{mL}^{-1} \\
25 \mu \mathrm{g} \mathrm{m}^{-1} \\
12.5 \mu \mathrm{g} \mathrm{mL}^{-1}\end{array}$ & $\begin{array}{l}\text { S. aureus (MIC); } \\
\text { E. coli (MIC); } \\
\text { B. cereus (MIC) }\end{array}$ & [85] \\
\hline 4-O- $\alpha$-D-Ribofuranose-2-pentyl-3-phemethylol (238) & Inhibition of $\alpha$-glucosidase & $2.50 \mu \mathrm{M}$ & $\mathrm{IC}_{50}$ & [82] \\
\hline Sumiki's acid (241) & Antibacterial & $5 \mu \mathrm{g} \operatorname{disc}^{-1}$ & B. subtilis $(7 \mathrm{~mm})$, S. aureus $(7 \mathrm{~mm})$ & [44] \\
\hline \multirow[b]{2}{*}{ Taxol (242) } & Cytotoxic & $3.5 \mu \mathrm{M}$ & HCT $15\left(\mathrm{IC}_{50}\right)$ & \multirow[b]{2}{*}{ [51] } \\
\hline & Antibacterial & $\begin{array}{l}30 \mu \mathrm{L} \operatorname{disc}^{-1} \\
20 \mu \mathrm{L} \operatorname{disc}^{-1} \\
30 \mu \mathrm{L} \operatorname{disc}^{-1} \\
20 \mu \mathrm{Ldisc} \\
40 \mu \mathrm{Ldisc}^{-1}\end{array}$ & $\begin{array}{c}\text { Pseudomonas aeruginosa }(2 \mathrm{~mm}) \\
\text { Escherichia coli }(3 \mathrm{~mm}) ; \\
\text { Klebsiella pneumoniae }(2 \mathrm{~mm}) \\
\text { Acetobacter } \mathrm{sp} . \\
\text { Bacillus subtilis }(1 \mathrm{~mm})\end{array}$ & \\
\hline Vermistatin (244) & Antibacterial & $25 \mu \mathrm{g} \mathrm{mL}^{-1}$ & S. aureus (MIC); & [85] \\
\hline
\end{tabular}


Another interesting correlation between chemical structure and bioactivity arises from the investigation on the inhibitory activity of cladosporol towards $\beta$-1,3-glucan synthetase. In fact, the epoxy-alcohol moiety in cladosporol is very similar to another $\beta$-1,3-glucan biosynthesis inhibitor, (+)-isoepoxydon; hence, the epoxy-alcohol structure seems to play an important role in the inhibitory activity of $\beta$-1,3-glucan synthetase [26].

\section{Conclusions}

As resulting from the available information examined in this review, data concerning secondary metabolite production and properties in Cladosporium are notable in quantitative terms. Indeed, the biosynthetic aptitudes of these fungi are quite original, with several series of products for which they represent the only source known so far. At the same time, at least some strains have resulted in the sharing of genetic bases for producing bioactive compounds previously reported from other fungal genera, such as cytochalasin D, brefeldin A, vermistatin, zeaenol, the coniochaetones, the malettinins and the viridotoxins, or even from plants, such as the gibberellins, plumbagin and taxol, which represent a direction for their possible biotechnological exploitation.

Besides implications deriving from the bioactive properties of some valuable products, metabolomics has been also used as a tool for species description and discrimination in several fungal genera, such as Penicillium, Talaromyces, Aspergillus [133], Alternaria [134] and Trichoderma [135]. The great diversity of secondary metabolites reported from Cladosporium spp. could represent a notable base material for verifying if a similar approach can be consistent for this genus as well. So far, the number of isolates that have been examined in this respect is too small, with as many as 23 of them not having been ascribed to any definite species, and the only consistent aspect resulting from the analysis of the available literature is represented by the production of tetramic acids by C. sphaerospermum. However, it is to be expected that the likely accumulation of new reports based on accurate molecular identification referring to the most recent taxonomic schemes may pave the way to a chemotaxonomic perspective for Cladosporium too.

Author Contributions: Conceptualization, R.N. and A.A.; writing-original draft preparation, M.M.S.; writing-review and editing, M.M.S., R.N. and A.A. All authors have read and agreed to the published version of the manuscript.

Funding: This research received no external funding.

Institutional Review Board Statement: Not applicable.

Informed Consent Statement: Not applicable.

Data Availability Statement: Not applicable.

Conflicts of Interest: The authors declare no conflict of interest.

\section{References}

1. Bensch, K.; Groenewald, J.Z.; Braun, U.; Dijksterhuis, J.; de Jesús Yáñez-Morales, M.; Crous, P.W. Common but different: The expanding realm of Cladosporium. Stud. Mycol. 2015, 82, 23-74. [CrossRef] [PubMed]

2. Segers, F.J.J.; Meijer, M.; Houbraken, J.; Samson, R.A.; Wösten, H.A.B.; Dijksterhuis, J. Xerotolerant Cladosporium sphaerospermum are predominant on indoor surfaces compared to other Cladosporium species. PLoS ONE 2015, 10, e0145415. [CrossRef]

3. Bensch, K.; Groenewald, J.Z.; Meijer, M.; Dijksterhuis, J.; Jurjević, Ž.; Andersen, B.; Houbraken, J.; Crous, P.W.; Samson, R.A. Cladosporium species in indoor environments. Stud. Mycol. 2018, 89, 177-301. [CrossRef] [PubMed]

4. Yew, S.M.; Chan, C.L.; Ngeow, Y.F.; Toh, Y.F.; Na, S.L.; Lee, K.W.; Hoh, C.C.; Yee, W.Y.; Ng, K.P.; Kuan, C.S. Insight into different environmental niches adaptation and allergenicity from the Cladosporium sphaerospermum genome, a common human allergy-eliciting Dothideomycetes. Sci. Rep. 2016, 6, 1-13. [CrossRef]

5. Cheng, S.C.H.; Lin, Y.Y.; Kuo, C.N.; Lai, L.J. Cladosporium keratitis-A case report and literature review. BMC Ophthalmol. 2015, 15, 1-5. [CrossRef] [PubMed]

6. Sandoval-Denis, M.; Gené, J.; Sutton, D.A.; Wiederhold, N.P.; Cano-Lira, J.F.; Guarro, J. New species of Cladosporium associated with human and animal infections. Persoonia Mol. Phylogeny Evol. Fungi 2016, 36, 281-298. [CrossRef] [PubMed]

7. Manos, P.S.; Zhou, Z.K.; Cannon, C.H. Systematics of Fagaceae: Phylogenetic tests of reproductive trait evolution. Int. J. Plant Sci. 2016, 162, 1361-1379. [CrossRef] 
8. Batra, N.; Kaur, H.; Mohindra, S.; Singh, S.; Shamanth, A.S.; Rudramurthy, S.M. Cladosporium sphaerospermum causing brain abscess, a saprophyte turning pathogen: Case and review of published reports. J. Mycol. Med. 2019, 29, 180-184. [CrossRef]

9. Rosado, A.W.C.; Custódio, F.A.; Pinho, D.B.; Ferreira, A.P.S.; Pereira, O.L. Cladosporium species associated with disease symptoms on Passiflora edulis and other crops in Brazil, with descriptions of two new species. Phytotaxa 2019, 409, 239-260. [CrossRef]

10. Iturrieta-González, I.; García, D.; Gené, J. Novel species of Cladosporium from environmental sources in Spain. MycoKeys 2021, 77, 1-25. [CrossRef]

11. Zimowska, B.; Becchimanzi, A.; Krol, E.D.; Furmanczyk, A.; Bensch, K.; Nicoletti, R. New Cladosporium species from normal and galled flowers of Lamiaceae. Pathogens 2021, 10, 369. [CrossRef]

12. Scott, P.M.; Van Walbeek, W.; MacLean, W.M. Cladosporin, a new antifungal metabolite from Cladosporium cladosporioides. J. Antibiot. 1971, 24, 747-755. [CrossRef]

13. Xiong, H.; Qi, S.; Xu, Y.; Miao, L.; Qian, P.Y. Antibiotic and antifouling compound production by the marine-derived fungus Cladosporium sp. F14. J. Hydro-Environ. Res. 2009, 2, 264-270. [CrossRef]

14. Setyaningrum, A.F.; Pratiwi, R.; Nasution, N.E.; Indrayanto, G. Identification of 4-4'-(1-methylethylidene)-bisphenol from the endophytic fungus Cladosporium oxysporum derived from Aglaia odorata. Alchemy J. Penelit. Kim. 2018, 14, 193-201. [CrossRef]

15. Ding, L.; Qin, S.; Li, F.; Chi, X.; Laatsch, H. Isolation, antimicrobial activity, and metabolites of fungus Cladosporium sp. associated with red alga Porphyra yezoensis. Curr. Microbiol. 2008, 56, 229-235. [CrossRef] [PubMed]

16. Waqas, M.; Khan, A.L.; Ali, L.; Kang, S.M.; Kim, Y.H.; Lee, I.J. Seed germination-influencing bioactive secondary metabolites secreted by the endophyte Cladosporium cladosporioides LWL5. Molecules 2013, 18, 15519-15530. [CrossRef]

17. Shaker, N.; Ahmed, G.; El-Sawy, M.; Ibrahim, H.; Ismail, H. Isolation, characterization and insecticidal activity of methylene chloride extract of Cladosporium cladosporioides secondary metabolites against Aphis gossypii (Glov.). J. Plant Prot. Pathol. 2019, 10, 115-119. [CrossRef]

18. Shaker, N.O.; Ahmed, G.M.M.; Ibrahim, H.Y.E.-S.; El-Sawy, M.M.; Mostafa, M.E.-H.; Ismail, H.N.A.E.-R. Secondary metabolites of the entomopathogenic fungus, Cladosporium cladosporioides and its relation to toxicity of cotton aphid. Int. J. Entomol. Nematol. 2019, 5, 115-120.

19. Gallo, M.L.; Seldes, A.M.; Cabrera, G.M. Antibiotic long-chain and $\alpha, \beta$-unsaturated aldehydes from the culture of the marine fungus Cladosporium sp. Biochem. Syst. Ecol. 2004, 32, 545-551. [CrossRef]

20. Sunesson, A.L.; Vaes, W.H.J.; Nilsson, C.A.; Blomquist, G.; Andersson, B.; Carlson, R. Identification of volatile metabolites from five fungal species cultivated on two media. Appl. Environ. Microbiol. 1995, 61, 2911-2918. [CrossRef]

21. Hulikere, M.M.; Joshi, C.G.; Ananda, D.; Poyya, J.; Nivya, T. Antiangiogenic, wound healing and antioxidant activity of Cladosporium cladosporioides (endophytic fungus) isolated from seaweed (Sargassum wightii). Mycology 2016, 7, 203-211. [CrossRef]

22. Liu, Y.; Kurt'n, T.; Wang, C.Y.; Han Lin, W.; Orfali, R.; Müller, W.E.G.; Daletos, G.; Proksch, P. Cladosporinone, a new viriditoxin derivative from the hypersaline lake derived fungus Cladosporium cladosporioides. J. Antibiot. 2016, 69, 702-706. [CrossRef]

23. San-Martin, A.; Painemal, K.; Díaz, Y.; Martinez, C.; Rovirosa, J. Metabolites from the marine fungus Cladosporium cladosporioides. An. Asoc. Quim. Argent. 2005, 93, 247-251.

24. Yehia, R.S.; Osman, G.H.; Assaggaf, H.; Salem, R.; Mohamed, M.S.M. Isolation of potential antimicrobial metabolites from endophytic fungus Cladosporium cladosporioides from endemic plant Zygophyllum mandavillei. S. Afr. J. Bot. 2020, 134, 296-302. [CrossRef]

25. Wang, X.; Radwan, M.M.; Taráwneh, A.H.; Gao, J.; Wedge, D.E.; Rosa, L.H.; Cutler, H.G.; Cutler, S.J. Antifungal activity against plant pathogens of metabolites from the endophytic fungus Cladosporium cladosporioides. J. Agric. Food Chem. 2013, 61, 4551-4555. [CrossRef]

26. Sakagami, Y.; Sano, A.; Hara, O.; Mikawa, T.; Marumo, S. Cladosporol, $\beta$-1, 3-glucan biosynthesis inhibitor, isolated from fungus, Cladosporium cladosporioides. Tetrahedron Lett. 1995, 36, 1469-1472. [CrossRef]

27. Wrigley, S.K.; Ainsworth, A.M.; Kau, D.A.; Martin, S.M.; Bahl, S.; Tang, J.S.; Hardick, D.J.; Rawlins, P.; Sadheghia, R.; Moorea, M. Novel reduced benzo [j] fluoranthen-3-ones from Cladosporium cf cladosporioides properties with cytokine production and tyrosine kinase Inhibitory. J. Antibiot. 2001, 54, 479-488.

28. Assante, G.; Bava, A.; Nasini, G. Enhancement of a pentacyclic tyrosine kinase inhibitor production in Cladosporium cf. cladosporioides by cladosporol. Appl. Microbiol. Biotechnol. 2006, 69, 718-721. [CrossRef]

29. Kobayashi, E.; Ando, K.; Nakano, H.; Tamaoki, T. UCN-1028A, a novel and specific inhibitor of protein kinase C, from Cladosporium. J. Antibiot. 1989, 42, 153-155. [CrossRef] [PubMed]

30. Kobayashi, E.; Ando, K.; Nakano, H.; Iida, T.; Tamaoki, T.; Ohno, H.; Morimoto, M. Calphostins (ucn-1028), novel and specific inhibitors of protein kinase C. I. Fermentation, isolation, physico-chemical properties and biological activities. J. Antibiot. 1989, 42, 1470-1474. [CrossRef] [PubMed]

31. Arnone, A.; Assante, G.; Merlini, L.; Nasini, G. Structure and stereochemistry of cladochrome D and E, novel perylenequinone pigments from Cladosporium cladosporioides. Gazz. Chim. Ital. 1990, 21, 557-559. [CrossRef]

32. Zhang, F.; Li, X.; Li, X.; Yang, S.; Meng, L. Polyketides from the mangrove-derived endophytic fungus Cladosporium cladosporioides. Mar. Drugs 2019, 17, 296. [CrossRef]

33. Zhang, F.Z.; Li, X.M.; Yang, S.Q.; Meng, L.H.; Wang, B.G. Thiocladospolides A-D, 12-membered macrolides from the mangrovederived endophytic fungus Cladosporium cladosporioides MA-299 and structure revision of pandangolide 3. J. Nat. Prod. 2019, 82, 1535-1541. [CrossRef] 
34. Zhang, F.Z.; Li, X.M.; Meng, L.H.; Wang, B.G. Cladocladosin A, an unusual macrolide with bicyclo 5/9 ring system, and two thiomacrolides from the marine mangrove-derived endophytic fungus, Cladosporium cladosporioides MA-299. Bioorg. Chem. 2020, 101, 103950. [CrossRef]

35. He, Z.H.; Zhang, G.; Yan, Q.X.; Zou, Z.B.; Xiao, H.X.; Xie, C.L.; Tang, X.X.; Luo, L.Z.; Yang, X.W. Cladosporactone A, a unique polyketide with 7-methylisochromen-3-one skeleton from the deep-sea-derived fungus Cladosporium cladosporioides. Chem. Biodivers. 2020, 17, e2000158. [CrossRef]

36. Reese, P.B.; Rawlings, B.J.; Ramer, S.E.; Vederas, J.C. Comparison of stereochemistry of fatty acid and cladosporin biosynthesis in Cladosporium cladosporioides using deuterium-decoupled proton, carbon-13 NMR shift correlation. J. Am. Chem. Soc. 1988, 110, 316-318. [CrossRef]

37. Jacyno, J.M.; Harwood, J.S.; Cutler, H.G.; Lee, M.K. Isocladosporin, a biologically active isomer of cladosporin from Cladosporium cladosporioides. J. Nat. Prod. 1993, 56, 1397-1401. [CrossRef]

38. Paul, D.; Park, K.S. Identification of volatiles produced by Cladosporium cladosporioides CL-1, a fungal biocontrol agent that promotes plant growth. Sensors 2013, 13, 13969-13977. [CrossRef] [PubMed]

39. Li, H.L.; Li, X.M.; Mandi, A.; Antus, S.; Li, X.; Zhang, P.; Liu, Y.; Kurtan, T.; Wang, B.G. Characterization of cladosporols from the marine algal-derived endophytic fungus Cladosporium cladosporioides EN-399 and configurational revision of the previously reported cladosporol derivatives. J. Org. Chem. 2017, 82, 9946-9954. [CrossRef] [PubMed]

40. Zhang, Z.; He, X.; Liu, C.; Che, Q.; Zhu, T.; Gu, Q.; Li, D. Clindanones A and B and cladosporols F and G, polyketides from the deep-sea derived fungus: Cladosporium cladosporioides HDN14-342. RSC Adv. 2016, 6, 76498-76504. [CrossRef]

41. Liu, H.X.; Tan, H.B.; Li, S.N.; Chen, Y.C.; Li, H.H.; Qiu, S.X.; Zhang, W.M. Two new 12-membered macrolides from the endophytic fungal strain Cladosprium colocasiae A801 of Callistemon viminalis. J. Asian Nat. Prod. Res. 2019, 21, 696-701. [CrossRef]

42. Venkateswarulu, N.; Shameer, S.; Bramhachari, P.V.; Basha, S.K.T.; Nagaraju, C.; Vijaya, T. Isolation and characterization of plumbagin (5- hydroxyl- 2- methylnaptalene-1,4-dione) producing endophytic fungi Cladosporium delicatulum from endemic medicinal plants: Isolation and characterization of plumbagin producing endophytic fungi from endemic. Biotechnol. Rep. 2018, 20, e00282. [CrossRef]

43. Wang, C.N.; Lu, H.M.; Gao, C.H.; Guo, L.; Zhan, Z.Y.; Wang, J.J.; Liu, Y.H.; Xiang, S.T.; Wang, J.; Luo, X.W. Cytotoxic benzopyranone and xanthone derivatives from a coral symbiotic fungus Cladosporium halotolerans GXIMD 02502. Nat. Prod. Res. 2020, 1-8. [CrossRef]

44. Jadulco, R.; Proksch, P.; Wray, V.; Sudarsono; Berg, A.; Gräfe, U. New macrolides and furan carboxylic acid derivative from the sponge-derived fungus Cladosporium herbarum. J. Nat. Prod. 2001, 64, 527-530. [CrossRef] [PubMed]

45. Jadulco, R.; Brauers, G.; Edrada, R.A.; Ebel, R.; Wray, V.; Sudarsono; Proksch, P. New metabolites from sponge-derived fungi Curvularia lunata and Cladosporium herbarum. J. Nat. Prod. 2002, 65, 730-733. [CrossRef]

46. Robeson, D.J.; Jalal, M.A. Formation of Ent-isophleichrome by Cladosporium herbarum isolated from sugar beet. Chem. Pharm. Bull. 1992, 56, 949-952.

47. Ye, Y.H.; Zhu, H.L.; Song, Y.C.; Liu, J.Y.; Tan, R.X. Structural revision of aspernigrin A, reisolated from Cladosporium herbarum IFB-E002. J. Nat. Prod. 2005, 68, 1106-1108. [CrossRef]

48. Hartanti, D.; Purwanti, D.I.; Putro, H.S.; Rateb, M.E.; Wongso, S.; Sugijanto, N.E.; Ebel, R.; Indrayanto, G. Isolation of pandangolide 1 from Cladosporium oxysporum, an endophyte of the terrestrial plant Alyxia reinwardtii. Makara J. Sci. 2015, 18, 123-126. [CrossRef]

49. Lu, Y.H.; Li, S.; Shao, M.W.; Xiao, X.H.; Kong, L.C.; Jiang, D.H.; Zhang, Y.L. Isolation, identification, derivatization and phytotoxic activity of secondary metabolites produced by Cladosporium oxysporum DH14, a locust-associated fungus. J. Integr. Agric. 2016, 15, 832-839. [CrossRef]

50. Wang, W.; Feng, H.; Sun, C.; Che, Q.; Zhang, G.; Zhu, T.; Li, D. Thiocladospolides F-J, antibacterial sulfur containing 12-membered macrolides from the mangrove endophytic fungus Cladosporium oxysporum HDN13-314. Phytochemistry 2020, 178, 112462. [CrossRef]

51. Gokul Raj, K.; Manikandan, R.; Arulvasu, C.; Pandi, M. Anti-proliferative effect of fungal taxol extracted from Cladosporium oxysporum against human pathogenic bacteria and human colon cancer cell line HCT 15. Spectrochim. Acta Part A Mol. Biomol. Spectrosc. 2015, 138, 667-674. [CrossRef]

52. Fan, Z.; Sun, Z.H.; Liu, H.X.; Chen, Y.C.; Li, H.H.; Zhang, W.M. Perangustols A and B, a pair of new azaphilone epimers from a marine sediment-derived fungus Cladosporium perangustm FS62. J. Asian Nat. Prod. Res. 2016, 18, 1024-1029. [CrossRef] [PubMed]

53. Yoshihara, T.; Shimanuki, T.; Araki, T.; Sakamura, S. Phleichrome; a new phytotoxic compound by Cladosporium phlei. Agric. Biol. Chem. 1975, 39, 1683-1684. [CrossRef]

54. Arnone, A.; Camarda, L.; Nasini, G.; Merlini, L. Secondary mould metabolites. Part 13. Fungal perylenequinones: Phleichrome, isophleichrome, and their endoperoxides. J. Chem. Soc. Perkin Trans. 1 1985, 1387-1392. [CrossRef]

55. Wu, G.; Sun, X.; Yu, G.; Wang, W.; Zhu, T.; Gu, Q.; Li, D. Cladosins A-E, hybrid polyketides from a deep-sea-derived fungus, Cladosporium sphaerospermum. J. Nat. Prod. 2014, 77, 270-275. [CrossRef]

56. Yu, G.H.; Wu, G.W.; Zhu, T.J.; Gu, Q.Q.; Li, D.H. Cladosins F and G, two new hybrid polyketides from the deep-sea-derived Cladosporium sphaerospermum 2005-01-E3. J. Asian Nat. Prod. Res. 2015, 17, 120-124. [CrossRef] [PubMed]

57. Hamayun, M.; Afzal Khan, S.; Ahmad, N.; Tang, D.S.; Kang, S.M.; Na, C.I.; Sohn, E.Y.; Hwang, Y.H.; Shin, D.H.; Lee, B.H.; et al. Cladosporium sphaerospermum as a new plant growth-promoting endophyte from the roots of Glycine max (L.) Merr. World J. Microbiol. Biotechnol. 2009, 25, 627-632. [CrossRef] 
58. Liang, X.; Huang, Z.H.; Ma, X.; Qi, S.H. Unstable tetramic acid derivatives from the deep-sea-derived fungus Cladosporium sphaerospermum EIODSF 008. Mar. Drugs 2018, 16, 448. [CrossRef] [PubMed]

59. Huang, Z.-h.; Nong, X.-h.; Liang, X.; Qi, S.-h. New tetramic acid derivatives from the deep-sea-derived fungus Cladosporium sp. SCSIO z0025. Tetrahedron 2018, 74, 2620-2626. [CrossRef]

60. Lee, S.R.; Lee, D.; Eom, H.J.; Rischer, M.; Ko, Y.J.; Kang, K.S.; Kim, C.S.; Beemelmanns, C.; Kim, K.H. Hybrid polyketides from a hydractinia-associated Cladosporium sphaerospermum SW67 and their putative biosynthetic origin. Mar. Drugs 2019, 17, 606. [CrossRef]

61. Rischer, M.; Lee, S.R.; Eom, H.J.; Park, H.B.; Vollmers, J.; Kaster, A.K.; Shin, Y.H.; Oh, D.C.; Kim, K.H.; Beemelmanns, C. Spirocyclic cladosporicin A and cladosporiumins I and J from a: Hydractinia-associated Cladosporium sphaerospermum SW67. Org. Chem. Front. 2019, 6, 1084-1093. [CrossRef]

62. Lee, S.R.; Kang, H.; Yoo, M.J.; Yi, S.A.; Beemelmanns, C.; Lee, J.; Kim, K.H. Anti-adipogenic pregnane steroid from a Hydractiniaassociated fungus, Cladosporium sphaerospermum sw67. Nat. Prod. Sci. 2020, 26, 230-235.

63. Pan, F.; El-Kashef, D.H.; Kalscheuer, R.; Müller, W.E.G.; Lee, J.; Feldbrügge, M.; Mándi, A.; Kurtán, T.; Liu, Z.; Wu, W.; et al. Cladosins L-O, new hybrid polyketides from the endophytic fungus Cladosporium sphaerospermum WBS017. Eur. J. Med. Chem. 2020, 191, 112159. [CrossRef]

64. Fujii, Y.; Fukuda, A.; Hamasaki, T.; Ichimoto, I.; Nakajima, H. Twelve-membered lactones produced by Cladosporium tenuissimum and the plant growth retardant activity of cladospolide B. Phytochemistry 1995, 40, 1443-1446. [CrossRef]

65. Fadhillah; Elfita; Muharni; Yohandini, H.; Widjajanti, H. Chemical compound isolated from antioxidant active extract of endophytic fungus Cladosporium tenuissimum in Swietenia mahagoni leaf stalks. Biodiversitas 2019, 20, 2645-2650.

66. Nasini, G.; Arnone, A.; Assante, G.; Bava, A.; Moricca, S.; Ragazzi, A. Secondary mould metabolites of Cladosporium tenuissimum, a hyperparasite of rust fungi. Phytochemistry 2004, 65, 2107-2111. [CrossRef] [PubMed]

67. Dai, H.Q.; Kang, Q.J.; Li, G.H.; Shen, Y.M. Three new polyketide metabolites from the endophytic fungal strain Cladosporium tenuissimum LR463 of Maytenus hookeri. Helv. Chim. Acta 2006, 89, 527-531. [CrossRef]

68. Naseer, S.; Bhat, K.A.; Qadri, M.; Riyaz-Ul-Hassan, S.; Malik, F.A.; Khuroo, M.A. Bioactivity-guided isolation, antimicrobial and cytotoxic evaluation of secondary metabolites from Cladosporium tenuissimum associated with Pinus wallichiana. ChemistrySelect 2017, 2, 1311-1314. [CrossRef]

69. De Medeiros, L.S.; Murgu, M.; de Souza, A.Q.L.; Rodrigues-Fo, F. Antimicrobial depsides produced by Cladosporium uredinicola, an endophytic fungus isolated from Psidium guajava fruits. Helv. Chim. Acta 2011, 94, 1077. [CrossRef]

70. Singh, B.; Sharma, P.; Kumar, A.; Chadha, P.; Kaur, R.; Kaur, A. Antioxidant and in vivo genoprotective effects of phenolic compounds identified from an endophytic Cladosporium velox and their relationship with its host plant Tinospora cordifolia. J. Ethnopharmacol. 2016, 194, 450-456. [CrossRef]

71. Gesner, S.; Cohen, N.; Ilan, M.; Yarden, O.; Carmeli, S. Pandangolide 1a, a metabolite of the sponge-associated fungus Cladosporium sp., and the absolute stereochemistry of pandangolide 1 and iso-cladospolide B. J. Nat. Prod. 2005, 68, 1350-1353. [CrossRef]

72. Sassa, T.; Ooi, T.; Nukina, M.; Ikeda, M.; Katct, N. Structural confirmation of Cotylenin A, a novel Fusicoccane-diterpene glycoside with potent plant growth-regulating activity from Cladosporium fungus sp. 501-7W. Biosci. Biotechnol. Biochem. 1998, 62, 1815-1818. [CrossRef]

73. Sassa, T.; Togashi, M.; Kitaguchi, T. The structures of cotylenins A, B, C, D and E. Agric. Biol. Chem. 1975, 39, 1735-1744. [CrossRef]

74. Sassa, T. Cotylenins, leaf growth substances produced by a fungus part I. Isolation and characterization of cotylenins A and B. Agric. Biol. Chem. 1971, 35, 1415-1418.

75. Qi, S.H.; Xu, Y.; Xiong, H.R.; Qian, P.Y.; Zhang, S. Antifouling and antibacterial compounds from a marine fungus Cladosporium sp. F14. World J. Microbiol. Biotechnol. 2009, 25, 399-406. [CrossRef]

76. Fan, C.; Zhou, G.; Wang, W.; Zhang, G.; Zhu, T.; Che, Q.; Li, D. Tetralone derivatives from a deep-sea-derived fungus Cladosporium sp. HDN17-58. Nat. Prod. Commun. 2021, 16,1-4.

77. Wang, F.W.; Jiao, R.H.; Cheng, A.B.; Tan, S.H.; Song, Y.C. Antimicrobial potentials of endophytic fungi residing in Quercus variabilis and brefeldin A obtained from Cladosporium sp. World J. Microbiol. Biotechnol. 2007, 23, 79-83. [CrossRef]

78. Wuringe; Guo, Z.K.; Wei, W.; Jiao, R.H.; Yan, T.; Zang, L.Y.; Jiang, R.; Tan, R.X.; Ge, H.M. Polyketides from the plant endophytic fungus Cladosporium sp. IFB3lp-2. J. Asian Nat. Prod. Res. 2013, 15, 928-933. [CrossRef]

79. Hosoe, T.; Okada, H.; Itabashi, T.; Nozawa, K.; Okada, K.; de Campos Takaki, G.M.; Fukushima, K.; Miyaji, M.; Kawai, K. A new pentanorlanostane derivative, cladosporide A, as a characteristic antifungal agent against Aspergillus fumigatus, isolated from Cladosporium sp. Chem. Pharm. Bull. 2000, 48, 1422-1426. [CrossRef] [PubMed]

80. Hosoe, T.; Okamoto, S.; Nozawa, K.; Kawai, K.I.; Okada, K.; De Campos Takaki, G.M. New pentanorlanostane derivatives, cladosporide B-D, as characteristic antifungal agents against Aspergillus fumigatus, isolated from Cladosporium sp. J. Antibiot. 2001, 54, 747-750. [CrossRef] [PubMed]

81. Wu, J.T.; Zheng, C.J.; Zhang, B.; Zhou, X.M.; Zhou, Q.; Chen, G.Y.; Zeng, Z.E.; Xie, J.L.; Han, C.R.; Lyu, J.X. Two new secondary metabolites from a mangrove-derived fungus Cladosporium sp. JJM22. Nat. Prod. Res. 2019, 33, 34-40. [CrossRef] [PubMed]

82. Zhang, B.; Wu, J.T.; Zheng, C.J.; Zhou, X.M.; Yu, Z.X.; Li, W.S.; Chen, G.Y.; Zhu, G.Y. Bioactive cyclohexene derivatives from a mangrove-derived fungus Cladosporium sp. JJM22. Fitoterapia 2021, 149, 104823. [CrossRef]

83. Ma, R.Z.; Zheng, C.J.; Zhang, B.; Yang, J.Y.; Zhou, X.M.; Song, X.M. Two new naphthalene-chroman coupled derivatives from the mangrove-derived fungus Cladosporium sp. JJM22. Phytochem. Lett. 2021, 43, 114-116. [CrossRef] 
84. Han, X.; Bao, X.-F.; Wang, C.-X.; Xie, J.; Song, X.-J.; Dai, P.; Chen, G.-D.; Hu, D.; Yao, X.-S.; Gao, H. Cladosporine A, a new indole diterpenoid alkaloid with antimicrobial activities from Cladosporium sp. Nat. Prod. Res. 2019, 35, 1-7. [CrossRef]

85. Bai, M.; Zheng, C.J.; Tang, D.Q.; Zhang, F.; Wang, H.Y.; Chen, G.Y. Two new secondary metabolites from a mangrove-derived fungus Cladosporium sp. JS1-2. J. Antibiot. 2019, 72, 779-782. [CrossRef]

86. Ai, W.; Lin, X.; Wang, Z.; Lu, X.; Mangaladoss, F.; Yang, X.; Zhou, X.; Tu, Z.; Liu, Y. Cladosporone A, a new dimeric tetralone from fungus Cladosporium sp. KcFL6' derived of mangrove plant Kandelia candel. J. Antibiot. 2015, 68, 213-215. [CrossRef]

87. Zhang, F.; Zhou, L.; Kong, F.; Ma, Q.; Xie, Q.; Li, J.; Dai, H.; Guo, L.; Zhao, Y. Altertoxins with quorum sensing inhibitory activities from the marine-derived fungus Cladosporium sp. KFD33. Mar. Drugs 2020, 18, 67. [CrossRef]

88. Shigemori, H.; Kasai, Y.; Komatsu, K.; Tsuda, M.; Mikami, Y.; Kobayashi, J. Sporiolides A and B, new cytotoxic twelve-membered macrolides from a marine-derived fungus Cladosporium species. Mar. Drugs 2004, 2, 164-169. [CrossRef]

89. Zhang, Z.; He, X.; Wu, G.; Liu, C.; Lu, C.; Gu, Q.; Che, Q.; Zhu, T.; Zhang, G.; Li, D. Aniline-tetramic acids from the deep-seaderived fungus Cladosporium sphaerospermum L3P3 cultured with the HDAC inhibitor SAHA. J. Nat. Prod. 2018, 81, 1651-1657. [CrossRef]

90. Khan, M.I.H.; Sohrab, M.H.; Rony, S.R.; Tareq, F.S.; Hasan, C.M.; Mazid, M.A. Cytotoxic and antibacterial naphthoquinones from an endophytic fungus, Cladosporium sp. Toxicol. Rep. 2016, 3, 861-865. [CrossRef] [PubMed]

91. Huang, C.; Chen, T.; Yan, Z.; Guo, H.; Hou, X.; Jiang, L.; Long, Y. Thiocladospolide E and cladospamide A, novel 12-membered macrolide and macrolide lactam from mangrove endophytic fungus Cladosporium sp. SCNU-F0001. Fitoterapia 2019, 137, 104246. [CrossRef]

92. Amin, M.; Zhang, X.Y.; Xu, X.Y.; Qi, S.H. New citrinin derivatives from the deep-sea-derived fungus Cladosporium sp. SCSIO z015. Nat. Prod. Res. 2020, 34, 1219-1226. [CrossRef]

93. Rotinsulu, H.; Yamazaki, H.; Sugai, S.; Iwakura, N.; Wewengkang, D.S.; Sumilat, D.A.; Namikoshi, M. Cladosporamide A, a new protein tyrosine phosphatase 1B inhibitor, produced by an Indonesian marine sponge-derived Cladosporium sp. J. Nat. Med. 2018, 72, 779-783. [CrossRef] [PubMed]

94. Zhu, M.; Gao, H.; Wu, C.; Zhu, T.; Che, Q.; Gu, Q.; Guo, P.; Li, D. Lipid-lowering polyketides from a soft coral-derived fungus Cladosporium sp. TZP29. Bioorg. Med. Chem. Lett. 2015, 25, 3606-3609. [CrossRef]

95. Silber, J.; Ohlendorf, B.; Labes, A.; Wenzel-Storjohann, A.; Näther, C.; Imhoff, J.F. Malettinin E, an antibacterial and antifungal tropolone produced by a marine Cladosporium strain. Front. Mar. Sci. 2014, 1, 35. [CrossRef]

96. Zhu, G.; Kong, F.; Wang, Y.; Fu, P.; Zhu, W. Cladodionen, a cytotoxic hybrid polyketide from the marine-derived Cladosporium sp. OUCMDZ-1635. Mar. Drugs 2018, 16, 71. [CrossRef]

97. Grove, J.F. New metabolic products of Aspergiullus flavus. Part I. Asperentin, its methyl ethers, and 5'-hydroxyasperentin. J. Chem. Soc. Perkin Trans. 1 1972, 2400-2406. [CrossRef]

98. De Medeiros, L.S.; Murgu, M.; de Souza, A.Q.L.; Rodrigues-Fo, E. Erratum: Antimicrobial depsides produced by Cladosporium uredinicola, an endophytic fungus isolated from Psidium guajava fruits. Helv. Chim. Acta 2011, 94, 1077-1084, Erratum in 2013, 96, 1406-1407. [CrossRef]

99. Mino, Y.; Idonuma, T.; Sakai, R. Effect of phleichrome by the Timothy leaf spot fungus, Cladosporium phlei on the invertases from the host leaves. Ann. Phytopath. Soc. Jpn. 1979, 45, 463-467. [CrossRef]

100. Hiort, J.; Maksimenka, K.; Reichert, M.; Perović-Ottstadt, S.; Lin, W.H.; Wray, V.; Steube, K.; Schaumann, K.; Weber, H.; Proksch, P.; et al. New natural products from the sponge-derived fungus Aspergillus niger. J. Nat. Prod. 2004, 67, 1532-1543. [CrossRef]

101. Gao, J.; Yang, S.; Qin, J. Azaphilones: Chemistry and Biology. Chem. Rev. 2013, 113, 4755-4811. [CrossRef]

102. Nicoletti, R.; Salvatore, M.M.; Andolfi, A. Secondary metabolites of mangrove-associated strains of Talaromyces. Mar. Drugs 2018, 16, 12. [CrossRef]

103. Bao, J.; Zhang, X.Y.; Dong, J.J.; Xu, X.Y.; Nong, X.H.; Qi, S.H. Cyclopentane-condensed chromones from marine-derived fungus Penicillium oxalicum. Chem. Lett. 2014, 43, 837-839. [CrossRef]

104. Zhang, X.; Li, S.J.; Li, J.J.; Liang, Z.Z.; Zhao, C.Q. Novel natural products from extremophilic fungi. Mar. Drugs 2018, 16, 194. [CrossRef] [PubMed]

105. Dewick, P.M. Medicinal Natural Products: A Biosyntheic Approach, 3rd ed.; John Wiley \& Sons: Hoboken, NJ, USA, 2016; ISBN 978-0-470-74168-9.

106. Flajs, D.; Peraica, M. Toxicological properties of citrinin. Arh. Hig. Rada Toksikol. 2009, 60, 457-464. [CrossRef]

107. Saeed, A. Isocoumarins, miraculous natural products blessed with diverse pharmacological activities. Eur. J. Med. Chem. 2016, 116, 290-317. [CrossRef]

108. Reveglia, P.; Masi, M.; Evidente, A. Melleins_-Intriguing natural compounds. Biomolecules 2020, 10, 772. [CrossRef] [PubMed]

109. Ellestad, G.A.; Mirando, P.; Kunstmann, M.P. Structure of the metabolite LL-S490 beta from an unidentified Aspergillus species. J. Org. Chem. 1973, 38, 24-25. [CrossRef] [PubMed]

110. Cutler, H.G.; Crumley, F.G.; Cox, R.H.; Hernandez, O.; Cole, R.J.; Dorner, J.W. Orlandin: A nontoxic fungal metabolite with plant growth inhibiting properties. J. Agric. Food Chem. 1979, 27, 592-595. [CrossRef]

111. Büchi, G.; Luk, K.C.; Kobbe, B.; Townsend, J.M. Four new mycotoxins of Aspergillus clavatus related to tryquivaline. J. Org. Chem. 1977, 42, 244-246. [CrossRef] [PubMed]

112. Hedden, P.; Sponsel, V. A century of gibberellin research. J. Plant Growth Regul. 2015, 34, 740-760. [CrossRef] 
113. Smith, C.J.; Abbanat, D.; Bernan, V.S.; Maiese, W.M.; Greenstein, M.; Jompa, J.; Tahir, A.; Ireland, C.M. Novel polyketide metabolites from a species of marine fungi. J. Nat. Prod. 2000, 63, 142-145. [CrossRef]

114. Hirota, A.; Sakai, H.; Isogai, A. New plant growth regulators, cladospolide A and B, macrolides produced by Cladosporium cladosporioides. Agric. Biol. Chem. 1985, 49, 731-735. [CrossRef]

115. Hirota, A.; Sakai, H.; Isogai, A.; Kitano, Y.; Ashida, T.; Hirota, H.; Takahashi, T. Absolute stereochemistry of cladospolide a, a phytotoxic macrolide from Cladosporium cladospor hides. Agric. Biol. Chem. 1985, 49, 903-904.

116. Hirota, H.; Hirota, A.; Sakai, H.; Isogai, A.; Takahashi, T. Absolute stereostructure determination of cladospolide A using MTPA ester method. Bull. Chem. Soc. Jpn. 1985, 58, 2147-2148. [CrossRef]

117. Félix, C.; Salvatore, M.M.; Dellagreca, M.; Meneses, R.; Duarte, A.S.; Salvatore, F.; Naviglio, D.; Gallo, M.; Jorrín-Novo, J.V.; Alves, A.; et al. Production of toxic metabolites by two strains of Lasiodiplodia theobromae, isolated from a coconut tree and a human patient. Mycologia 2018, 110, 642-653. [CrossRef] [PubMed]

118. Salvatore, M.M.; Alves, A.; Andolfi, A. Secondary metabolites of Lasiodiplodia theobromae: Distribution, chemical diversity, bioactivity, and implications of their occurrence. Toxins 2020, 12, 457. [CrossRef]

119. Qiu, H.Y.; Wang, P.F.; Lin, H.Y.; Tang, C.Y.; Zhu, H.L.; Yang, Y.H. Naphthoquinones: A continuing source for discovery of therapeutic antineoplastic agents. Chem. Biol. Drug Des. 2018, 91, 681-690. [CrossRef]

120. Salvatore, M.M.; Alves, A.; Andolfi, A. Secondary metabolites produced by Neofusicoccum species associated with plants: A review. Agriculture 2021, 11, 149. [CrossRef]

121. Iida, T.; Kobayashi, E.; Yoshida, M. Calphostins, novel and specific inhibitors of protein kinase C. J. Antibiot. 1989, 42, $1475-1481$. [CrossRef] [PubMed]

122. Stack, M.E.; Prival, M.J. Mutagenicity of the Alternaria metabolites altertoxins I, II, and III. Appl. Environ. Microbiol. 1986, 52, 718-722. [CrossRef] [PubMed]

123. Bhat, Z.S.; Rather, M.A.; Maqbool, M.; Lah, H.U.; Yousuf, S.K.; Ahmad, Z. $\alpha$-Pyrones: Small molecules with versatile structural diversity reflected in multiple pharmacological activities-an update. Biomed. Pharmacother. 2017, 91, 265-277. [CrossRef] [PubMed]

124. McGlacken, G.P.; Fairlamb, I.J.S. 2-Pyrone natural products and mimetics: Isolation, characterisation and biological activity. Nat. Prod. Rep. 2005, 22, 369-385. [CrossRef] [PubMed]

125. Kobayashi, Y.; Nakano, M.; Biju Kumar, G.; Kishihara, K. Efficient conditions for conversion of 2-substituted furans into 4oxygenated 2-enoic acids and its application to synthesis of (+)-aspicilin, (+)-patulolide a, and (-)-pyrenophorin. J. Org. Chem. 1998, 63, 7505-7515. [CrossRef]

126. Dos Santos Dias, A.C.; Couzinet-Mossion, A.; Ruiz, N.; Lakhdar, F.; Etahiri, S.; Bertrand, S.; Ory, L.; Roussakis, C.; Pouchus, Y.F.; Nazih, E.H.; et al. Steroids from marine-derived fungi: Evaluation of antiproliferative and antimicrobial activities of eburicol. Mar. Drugs 2019, 17, 372. [CrossRef]

127. Rodrigues, M.L. The multifunctional fungal ergosterol. MBio 2018, 9, e01755. [CrossRef]

128. De Tommaso, G.; Salvatore, M.M.; Nicoletti, R.; DellaGreca, M.; Vinale, F.; Bottiglieri, A.; Staropoli, A.; Salvatore, F.; Lorito, M.; Iuliano, M.; et al. Bivalent metal-chelating properties of harzianic acid produced by Trichoderma pleuroticola associated to the gastropod Melarhaphe neritoides. Molecules 2020, 25, 2147. [CrossRef] [PubMed]

129. De Tommaso, G.; Salvatore, M.M.; Nicoletti, R.; Dellagreca, M.; Vinale, F.; Staropoli, A.; Salvatore, F.; Lorito, M.; Iuliano, M.; Andolfi, A. Coordination properties of the fungal metabolite harzianic acid toward toxic heavy metals. Toxics 2021, 9, 19. [CrossRef]

130. Nicoletti, R.; Fiorentino, A. Plant bioactive metabolites and drugs produced by endophytic fungi of Spermatophyta. Agriculture 2015, 5, 918-970. [CrossRef]

131. Negi, J.S.; Bisht, V.K.; Singh, P.; Rawat, M.S.M.; Joshi, G.P. Naturally occurring xanthones: Chemistry and biology. J. Appl. Chem. 2013, 3, 1-11. [CrossRef]

132. Nicoletti, R.; Manzo, E.; Ciavatta, M.L. Occurence and bioactivities of funicone-related compounds. Int. J. Mol. Sci. 2009, 10, 1430-1444. [CrossRef]

133. Houbraken, J.; Kocsubé, S.; Visagie, C.M.; Yilmaz, N.; Wang, X.C.; Meijer, M.; Kraak, B.; Hubka, V.; Bensch, K.; Samson, R.A.; et al. Classification of Aspergillus, Penicillium, Talaromyces and related genera (Eurotiales): An overview of families, genera, subgenera, sections, series and species. Stud. Mycol. 2020, 95, 5-169. [CrossRef] [PubMed]

134. Zwickel, T.; Kahl, S.M.; Rychlik, M.; Müller, M.E.H. Chemotaxonomy of mycotoxigenic small-spored Alternaria fungi-Do multitoxin mixtures act as an indicator for species differentiation? Front. Microbiol. 2018, 9, 1368. [CrossRef] [PubMed]

135. Kang, D.; Kim, J.; Choi, J.N.; Liu, K.H.; Lee, C.H. Chemotaxonomy of Trichoderma spp. using mass spectrometry-based metabolite profiling. J. Microbiol. Biotechnol. 2011, 21, 5-13. [CrossRef] [PubMed] 